SPRINGER BRIEFS IN LAW

María de Miguel Molina

Virginia Santamarina Campos Editors

Ethics and Civil

Drones

European Policies

and Proposals for

the Industry

Springer Open 
SpringerBriefs in Law 
More information about this series at http://www.springer.com/series/10164 
María de Miguel Molina

Virginia Santamarina Campos

Editors

\section{Ethics and Civil Drones}

European Policies and Proposals for the Industry

Springer Open 


\section{Editors}

María de Miguel Molina

Department of Management

Polytechnic University of Valencia

Valencia

Spain

\author{
Virginia Santamarina Campos \\ Conservation and Restoration of Cultural \\ Heritage \\ Polytechnic University of Valencia \\ Valencia \\ Spain
}

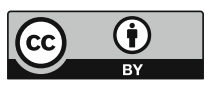

ISSN 2192-855X

SpringerBriefs in Law

ISBN 978-3-319-71086-0

https://doi.org/10.1007/978-3-319-71087-7

Library of Congress Control Number: 2017959312
ISSN 2192-8568 (electronic)

ISBN 978-3-319-71087-7 (eBook)

(C) The Editor(s) (if applicable) and The Author(s) 2018. This book is an open access publication.

Open Access This book is licensed under the terms of the Creative Commons Attribution 4.0 International License (http://creativecommons.org/licenses/by/4.0/), which permits use, sharing, adaptation, distribution and reproduction in any medium or format, as long as you give appropriate credit to the original author(s) and the source, provide a link to the Creative Commons license and indicate if changes were made.

The images or other third party material in this book are included in the book's Creative Commons license, unless indicated otherwise in a credit line to the material. If material is not included in the book's Creative Commons license and your intended use is not permitted by statutory regulation or exceeds the permitted use, you will need to obtain permission directly from the copyright holder.

The use of general descriptive names, registered names, trademarks, service marks, etc. in this publication does not imply, even in the absence of a specific statement, that such names are exempt from the relevant protective laws and regulations and therefore free for general use.

The publisher, the authors and the editors are safe to assume that the advice and information in this book are believed to be true and accurate at the date of publication. Neither the publisher nor the authors or the editors give a warranty, express or implied, with respect to the material contained herein or for any errors or omissions that may have been made. The publisher remains neutral with regard to jurisdictional claims in published maps and institutional affiliations.

Printed on acid-free paper

This Springer imprint is published by Springer Nature

The registered company is Springer International Publishing AG

The registered company address is: Gewerbestrasse 11, 6330 Cham, Switzerland 


\section{Foreword}

Aviation has come a long way since the Montgolfier brothers carried out the first free flight of a hot air balloon across Paris in 1783. It took a further 120 years before the Wright brothers achieved sustained controlled powered flight in 1903. Not too long after that, the first scheduled commercial air passenger flight took off in 1914 across Tampa Bay, Florida. The aviation sector has seen tremendous advances both in relation to the technology and volume of air traffic since that first commercial flight. Whilst the civil aviation section generally has relied on human piloted aircrafts, unmanned 'pilotless' drones have also been developing alongside, albeit at a much smaller scale. Until the not too distant past, the uses of drones have been mainly confined to military and surveillance purposes. The significance of drones has, however, increased substantially in the recent years in the light of its use in various other sectors including agriculture, inspection, media and entertainment, as well as by hobbyists. It will only be a matter of time before remotely piloted aircrafts enter the realm of commercial flights.

Drones come in a variety of sizes, weight and designs. The regulation of drones is also equally diverse. Internationally, whilst the traditional aviation industry has been subject to the framework of an international convention, it is fair to state that no such cohesive international standard or guidelines exist for civil drones. In the European Union, the regulation of unmanned aircraft systems with a maximum take-off mass of less than $150 \mathrm{~kg}$ is a matter for individual member states. This has resulted in a lack of consistent and higher standard of regulation across the EU, which has obvious implications for safety and privacy. This is, however, expected to change in the light of the current initiatives for a new regulation that aims to bring all drones, regardless of weight, within the purview of the European Union legal framework.

Law has a difficult job to do in terms of adapting and rising up to ever-changing technologies, without posing a hindrance to innovation and growth. It is imperative that there is a forward-looking, harmonized and appropriate legal framework in place across the European Union in order to support and create a safe, secure and privacy-protected environment for drones to operate. A hallmark of 'good law making' in this respect should be that regulation should not hinder growth and 
development of the sector by putting European companies at a disadvantage over their (mostly Chinese and US) competitors, but at the same time, it should ensure that the safety and privacy of the operators and the public are protected. It is in this context that this book is highly relevant — not just for policy makers, but also for the producers, operators and users (commercial, civil and casual) of drones regardless of size, weight and configuration.

I have a keen interest in the interaction between law and technology and in particular the challenges the latter raises for the law. I am delighted to have the opportunity to write a Foreword for this book, which considers an area that is very topical but at the same time is in need of more research. In that sense, this book makes a very useful contribution to this field of study. The focus of this book is on professional drones (for, e.g., those used for aerial photography) and commercial drones (for, e.g., those used in precision agriculture, infrastructure inspection and other industrial use), but it also considers casual private use (hobby) to a certain extent. This book starts with an overview of the European Union level policies and regulation that govern civil drones, and the authors argue that the current regulatory framework acts as an impediment for the growth of the drone industry. The authors undertake a useful comparative analysis of the current regulatory framework in Belgium, Spain and the UK, which reveals the adverse impact the lack of harmonization of laws has on the European drone sector as a whole. In the final chapter, the authors endeavour to explore the legal and ethical considerations behind regulation and examine the various regulatory models including self-regulation and co-regulation from a cross-jurisdictional perspective. In particular, they argue that manufacturers of drones should work closely with operators and advocate industry codes of conduct and best practices to ensure the safety, security and privacy of all stakeholders.

As the drone industry takes off further to dizzying heights, it will transform the skies as we see it today. The current legislative initiative at European level to strengthen the regulation of drones will result in one of the significant watershed moments for aviation laws. This book could not be timelier in the light of the ongoing developments in the European Union and beyond.

Abhilash Nair

Senior Lecturer in Internet Law, Aston University, UK Co-editor, European Journal of Law and Technology 


\section{Contents}

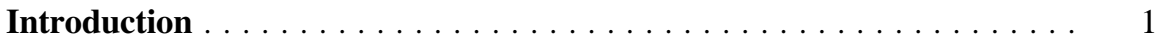

Virginia Santamarina Campos, María de Miguel Molina

and Stephan Kröner

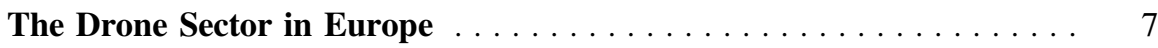

Blanca de Miguel Molina and Marival Segarra Oña

European Union Policies and Civil Drones . . . . . . . . . . . . . . 35

Virginia Santamarina Campos

Spain-UK-Belgium Comparative Legal Framework: Civil Drones for

Professional and Commercial Purposes . . . . . . . . . . . . . . . . . 43

Miguel Rosa, Gavin O’Brien and Vadim Vermeiren

Legal and Ethical Recommendations . . . . . . . . . . . . . . . . . 77

María de Miguel Molina and María Ángeles Carabal Montagud

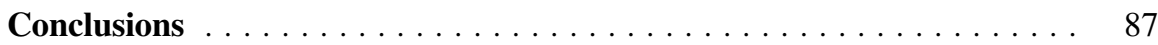

Virginia Santamarina Campos and Stephan Kröner

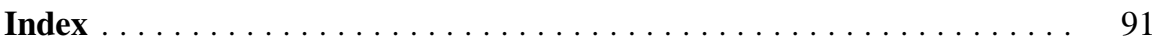




\section{Abbreviations}

$\begin{array}{ll}\text { AEDRON } & \text { Spanish Association of Drones and Similar } \\ \text { AESA } & \text { Spanish Safety Aviation Agency } \\ \text { AIP } & \text { Aeronautical Information Package } \\ \text { AiRT } & \text { Technology Transfer of RPAs for the Creative Industry } \\ \text { ANS } & \text { Air Navigation Service } \\ \text { ARPAS-UK } & \text { Association of RPAs } \\ \text { ATM } & \text { Air Traffic Management } \\ \text { ATO } & \text { Approved Training Organization } \\ \text { BCAA } & \text { Belgium Civil Aviation Authority } \\ \text { BeUAS } & \text { La Fédération Belge de l'Aviation Télépilote } \\ \text { BRLOS } & \text { Beyond Direct Radio Line of Sight } \\ \text { BVLOS } & \text { Beyond Visual Line of Sight } \\ \text { CAA } & \text { Civil Aviation Authority (UK) } \\ \text { CEO } & \text { Chief Executive Officer } \\ \text { CIs } & \text { Creative Industries } \\ \text { COM SP } & \text { Communication Service Provider } \\ \text { CONOPS } & \text { Concepts of Operations } \\ \text { CTR } & \text { Controlled Traffic Region } \\ \text { D\&A } & \text { Detect and Avoid System } \\ \text { DGTA } & \text { Générale Transport Aérien (Belgium) } \\ \text { DOA } & \text { Approved Design Organization } \\ \text { EASA } & \text { European Aviation Safety Agency } \\ \text { ENAC } & \text { Italian Civil Aviation Authority } \\ \text { ESRG } & \text { European RPAS Steering Group } \\ \text { EU } & \text { European Union } \\ \text { EVLOS } & \text { Extended Visual Line of Sight } \\ \text { FIZ } & \text { Flight Information Zone } \\ \text { GCS } & \text { Ground Control Station } \\ \text { IAA } & \text { Ireland Aviation Authority } \\ \text { ICAO } & \text { International Civil Aviation Organization } \\ & \end{array}$


ICT Information and Communication Technologies

IFR Instrument Flight Rule

IPS Indoor Positioning System

JARUS Joint Authorities for Regulation of Unmanned Systems

LAPL Light Aircraft Pilot Licence

MTOW Maximum Take-Off Weight

NAAs National Aviation Authorities

NATO North Atlantic Treaty Organization

NOTAM Notice to Airmen

OACI International Civil Aviation Organization

$\mathrm{QE}$

Qualified Entity

RLOS Direct Radio Line of Sight

RPA Remotely Piloted Aircraft

RPAS Remotely Piloted Aircraft System

SARPs Standards and Recommended Practices

SERA Standard European Rules of the Air

SMEs Small- and Medium-Sized Enterprises

SORA Specific Operational Risk Assessment Specifications

TBD To Be Determined

TLS Tolerable Level of Safety

UAS Unmanned Aerial System

UAV Unmanned Aerial Vehicle

UCAV Unmanned Combat Aerial Vehicle

UK United Kingdom

UPV Universitat Politècnica de València

USA The United States of America

VLOS Visual Line of Sight 


\title{
Introduction
}

\author{
Virginia Santamarina Campos, María de Miguel Molina \\ and Stephan Kröner
}

\begin{abstract}
The aim of this book is to disseminate part of the results of the H2020 European Project AiRT (Technology Transfer of RPAs for the Creative Industry). In particular, we want to present some results to mitigate safety and security concerns when piloting civil drones in the service sector. European policies concerning drones in general are focused on outdoor drone use, but drones can also be employed indoors. Moreover, European countries have fragmented regulations about the use of drones; therefore, European institutions are endeavouring to combine all these regulations. In this sense not only law but also ethics play a key role in providing the industry with guidelines to gain citizens' trust. Therefore, our work is based on four pillars:

1. An analysis of the drone sector in Europe;

2. An in-depth study of the European policies;

3. A comparative analysis of the regulations of some European countries;

4. Primary data from members of the creative industry.
\end{abstract}

With these results we would like to give advice to the European industry as well as providing new insights for policy makers and the scientific community. The project has received funding from the European Union's Horizon 2020 research and innovation programme under grant agreement no. 732433 (reference: H2020-ICT2016-2017, www.airt.eu). This book reflects the views of the authors and not necessary the position of the Commission.

\section{Scope of the Book}

The AiRT project runs from January 2017 to June 2018. The consortium brings together a group of partners from three European countries with a complementary and outstanding range of experiences, skills, competences, and resources.

V. Santamarina Campos $(\bowtie) \cdot$ M. de Miguel Molina $\cdot$ S. Kröner

Universitat Politècnica de València, Valencia, Spain

e-mail: virsanca@upv.es 
The Universitat Politècnica de València (UPV, Spain) combines experts in creative industries (CIs) on one hand and specialists in robotics and innovative information and communication technology (ICT) solutions on the other hand. From the perspective of specialists in creative activities and aerial filming, Clearhead Media Ltd (UK) has experience in the use of RPASs as a professional filming tool for outdoor purposes. AeroTools UAV-Unmanned Aerial Vehicles (Spain) specializes in developing RPAS systems. It relies on substantial experience in the development of RPAS operation systems, which include advanced functionalities such as automatic obstacle detection, encrypted communication systems, and autonomous RPAS navigation. Pozyx Labs BVBA (Belgium) has developed a novel IPS (indoor positioning system) with which highly precise indoor coordinates can be obtained.

Why is a book on good practices needed?

As will be illustrated very clearly in the second chapter, the drone market presents a real opportunity to foster job creation and a source of innovation and economic growth. For Europe, for instance, about 150,000 jobs are forecast by the AeroSpace and Defence Industries Association of Europe by 2050, excluding employment generated through operator services (European Commission 2014). However, the EU Subcommittee on Civil Use of Drones believes that this approach to estimating job creation through drone operations results in significant underestimations, since it excludes completely new areas of activity that are not necessarily classified as aviation (e.g. surveys, creative industry activities, etc.) (House of Lords 2014). Moreover, the drone industry will not only create new qualified jobs but will foster the emergence of a totally new service industry offering drone operations and aerial work to commercial and state customers. Nevertheless, the legal situation differs in each European country, and technology advances require fast adaption of laws, since special flight environments, like confined spaces, are mostly not considered. These legal uncertainties hinder the exploitation, especially in Europe, of this big and very dynamic market.

Consequently, one focus of this book is the elaboration of a proposal for European legislation for indoor RPAS safety, including both ethical/security and safety risk issues. It will provide recommendations for policies for the European regions and the EU Government, including recommendations to alter the law where necessary and to overcome obstacles (if found) that hinder the use of drones indoors. Although this might seem to be a very challenging task at first glance, when we analysed indoor issues, we reached the conclusion that many of them can be treated in the same way as when operating outdoors. Apart from that, we noticed that, in some European countries, small indoor drones are not considered by any regulation with the exception of professional work.

To which types of drones are the recommendations described in the following chapters of this book addressed?

As will be explained in more detail in the chapter "European Union Policies and Civil Drones", the first rough subdivision/classification of drones can be made according to their mission: military or civilian. The AiRT project has the main goal of providing small and medium-sized creative industries with a drone (more precisely an RPAS - remotely piloted aircraft system) specifically designed for indoor 
use, which will enable these companies to expand their creativity and offer new and improved services. Thus, in this policy book, we focus on the civilian use of drones for professional and commercial purposes.

As will be discussed in the chapter "The Drone Sector in Europe", the drone market is very large and has tens of applications. As Hassanalian and Abdelkefi (2017) explain, drones can also be classified in the first step according to their flight zone/environment: indoors or outdoors. It has to be kept in mind that the current legislation in the different European countries mainly focuses on the regulation of outdoor use. Here we analyse the current legal state and try to provide some recommendations for proper indoor professional use as well.

Complex matters usually require the cooperation of all the different parties involved, working together in an inter-/transdisciplinary team. Thus, to provide feasible proposals, the AiRT consortium brings together partners from three European countries with complementary experiences, skills, competences, and resources. Therefore, experts in finding ICT solutions for complex topics related to robotics, pioneers in the development of ultra-wideband-based indoor positioning systems for moving objects, drone manufacturers, and specialists in creative activities and aerial filming worked together on the guideline for this good-practice book.

It is important to emphasize that the scenario for which the AiRT project was developed-flying indoors - is not specifically regulated either by the European Aviation Safety Agency (EASA) or by national aviation authorities. As a general rule, these bodies regulate the operation of aircraft only in open airspace, paying no attention to aircraft flying under a ceiling (indoors). This means that a drone operator can fly a drone inside a roofed building with no restriction, and only the permission of the owner is needed. However, this possibility normally fails, since additional issues must be taken into account, such as the civil liability of the operator or the owner in the case of an incident or accident. In other words, since the factual and legal positions are not clarified, the owner or the insurer usually refuses to grant authorization.

The definition of an "indoor space", in terms of regulated operation by civil aviation bodies, is not explicit, but it is generally accepted that indoors means any airspace under a fixed roof or ceiling that could prevent an aircraft from gaining altitude beyond this point. Whether this space has vertical walls or not is irrelevant. In terms of safety, indoor operation offers some positive aspects:

- Short range of flight.

- Always flying with visual line of sight (VLOS), although obstacles can generate shaded areas.

- Short flight time.

- Lack of meteorological variations that might disturb the flight operation.

- Enough resources at hand to provide easy operation (plugs, electrical power, short distances, easy communication, etc.). 
On the other hand, violation of privacy, particularly related to private property, such as gathering geographic information (images via satellite, aeroplanes, or drones), has always been an issue for aerial filming. Thus, to maintain high ethical standards, the consideration of ethical research conduct should be part of the project from the very beginning, as ethics are relevant at all stages. In the case of indoor use, it is essential to distinguish between private and public property. In the latter case, the permission of the people affected is a key point. Even in the case of police investigations, the concept of home intromission has been highlighted by the courts. For example, the Spanish Supreme Court (2016), in its Sentence no. 329, 2nd Room, Criminal Court, 20 April 2016, did not accept recorded images made with a drone by the police, as there was no judicial authorization or property permission to film inside that house.

\section{Brief Overview of the Different Chapters of the Book}

The chapter "The Drone Sector in Europe" illustrates the economic potential of the steadily growing drone market, in Europe as well as China and the US. The latter markets are considered to be the main ones competing with the European one, and, as can be seen in the following chapters, non-uniform European laws may lead to a competitive disadvantage of European companies, in particular SMEs. Therefore, an in-depth analysis of drone applications for professional use by different industries, such as agriculture, media, mining, energy, construction, and so on, has been performed. In addition, special attention has been paid to the creative industry sector, which is particularly affected by the legal confusion. Thus, the importance of a common European framework can be understood, and it is apparent that currently the regulatory barrier seems to be the main impediment to the definitive taking off of the drone industry (Pauner et al. 2015).

In the chapter "European Policies and Civil Drones", the authors analyse the drone policies in the European Union, providing a breakdown of the different types of actors, drones, licenses, and insurance at the European and national levels. Moreover, the ways in which all these policies affect producers and operators are considered. The problems related to licenses, the type of drone and activity, and the opportunity to have insurance can influence the development of the drone industry in the future.

In the chapter "Spain-UK-Belgium Comparative Legal Framework", the different legal frameworks from Spain, the UK, and Belgium are exposed. The CEOs (Chief Executive Officers) of the three companies participating in the project compare their regulations to illustrate the similarities and differences regarding civil drones, not only for outdoor use but also for indoor use. Here the urgency of the pending common European regulatory framework can be seen, and the authors highlight how this could reduce many of the current legal uncertainties.

The chapter "Legal and Ethical Recommendations" is dedicated to legal and above all ethical recommendations. As technology is difficult to regulate, other 
tools, such as co-regulation and self-regulation, although they can be considered as soft instruments, are useful alternatives for manufacturers and operators of civil drones (Stöcker et al 2017). As part of this project, we organized and held focus groups with drone operators in the three participating countries. Including previous research and the results of these focus group activities, the authors provide recommendations for producers, drone operators, and policy makers. The recommendations cover safety, security, and privacy aspects. Bearing in mind that at present some countries do not regulate the use of drones indoors, drone design by default and professional experience are the most important parameters to guarantee safe and secure drone flights indoors.

\section{References}

European Commission (2014) Communication from the Commission to the European Parliament and the Council. A new era for aviation. Opening the aviation market to the civil use of remotely piloted aircraft systems in a safe and sustainable manner. Available via EUR-LEX. http://eur-lex.europa.eu/legal-content/EN/TXT/?uri=CELEX\%3A52014DC0207. Accessed 8 September 2017

Hassanalian M, Abdelkefi A (2017) Classifications, applications, and design challenges of drones: a review. Prog in Aerosp Sci 91(May):99-131

House of Lords (2014) EU subcommittee B on civil use of remotely piloted aircraft systems (RPAS). Oral and written evidence. Available via Parliament. http://www.parliament.uk/civilrpas. Accessed 8 September 2017

Pauner C, Kamara I, Viguri J (2015) Drones. Current challenges and standardisation solutions in the field of privacy and data protection. ITU Kaleidosc: trust in the information society (K-2015), pp 1-7

Spanish Supreme Court (2016) Sentence no. 329, 2nd room, criminal court. Available via vLEX. https://supremo.vlex.es/vid/637465649\#section_6. Accessed 18 August 2017

Stöcker C, Bennett R, Nex F, Gerke M, Zevenbergen J (2017) Review of the current state of UAV regulations. Remote Sens 9(5):459-485

Open Access This chapter is licensed under the terms of the Creative Commons Attribution 4.0 International License (http://creativecommons.org/licenses/by/4.0/), which permits use, sharing, adaptation, distribution and reproduction in any medium or format, as long as you give appropriate credit to the original author(s) and the source, provide a link to the Creative Commons license and indicate if changes were made.

The images or other third party material in this chapter are included in the chapter's Creative Commons license, unless indicated otherwise in a credit line to the material. If material is not included in the chapter's Creative Commons license and your intended use is not permitted by statutory regulation or exceeds the permitted use, you will need to obtain permission directly from the copyright holder.

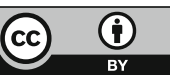




\title{
The Drone Sector in Europe
}

\author{
Blanca de Miguel Molina and Marival Segarra Oña
}

\begin{abstract}
The aim of this chapter is to review the industry sector in Europe, which involves big companies as well as SMEs. The leading European countries, the main competitors, and the main competitive advantages of the industry are analysed. We have identified five different segments in which companies compete based on distinctive features (toys, hobby/leisure, professional, commercial, and military). The homogenization of the industry, especially in the toy, hobby, and commercial subsectors, is mainly led by big companies, which at the same time also represent the largest market share. We have concluded that there are no entry barriers besides technology and commercial distribution, but the main difficulty that is hampering the industry's expansion is regulation. This affects in particular the hobby/leisure and commercial drone segments, some areas more than others; while agricultural and military drones are expanding and evolving rapidly, professional filming and photography and toys are still too dependent on safety or legal issues, such as privacy concerns. It is also remarkable that companies from China and the USA are reaching the top positions. This should be taken into consideration by European policy makers, as the decisions made in the next years will be the key to the development of the sector in Europe.
\end{abstract}

\section{Introduction}

Why is it important to analyse the drone market first? There are two main reasons. Firstly, it illustrates the potential of this steadily growing market, which, due to the lack of unification of national laws in a common European regulation, is not fully exploited. Secondly, it shows why it is so difficult to reach a common agreement:

B. de Miguel Molina $(\bowtie) \cdot$ M. Segarra Oña

Department of Management, Universitat Politècnica de València, Valencia, Spain

e-mail: bdemigu@omp.upv.es

(C) The Author(s) 2018

M. de Miguel Molina and V. Santamarina Campos (eds.), Ethics and Civil Drones,

SpringerBriefs in Law, https://doi.org/10.1007/978-3-319-71087-7_2 
tens of drone application and thus drone characteristics (e.g., size, weight, engine power, range of the aircraft, etc.) exist. Thus, before regulating markets (drones), first the market has to be described and analysed in detail to find a proper solution that pleases all: industry, governments, the military, researchers, and the general public.

How can we define the drone industry? This question needs to be answered to structure the information, since up to now information regarding drones has not been easy to find. This might be because the regulations do not fully support their use, because military uses are still the most common ones and the army industry treats everything as strictly secret, because technology is developing so fast that sharing information would help competitors, or because the rise of the industry is so fast that there is no time to analyse data and research the insights or to disseminate news.

Although difficulties exist, we will retrieve information regarding the drone industry and restructure it to try to provide readers with an engaging chapter that helps them to understand the main facts, characteristics, and strategic opportunities that the industry currently offers.

The Cambridge English Dictionary offers two definitions of a drone:

- an aircraft that does not have a pilot but is controlled by someone on the ground and is used especially for dropping bombs or for surveillance (meaning careful watching of a place);

- an aircraft without a pilot that is controlled by someone on the ground and is used especially as a hobby.

These definitions are very useful, as they clarify not only the meaning but also the main uses of drones. In the second definition, we could include different uses that have recently appeared, such as safety purposes, transport and delivery, and so on. As there is no unique word to name an aircraft without a pilot, it is also quite usual to find the following definitions:

UAV (Unmanned Aerial Vehicle)

UAS (Unmanned Aerial System)

UCAV (Unmanned Combat Aerial Vehicle)

RPA (Remotely Piloted Aircraft)

RPAS (Remotely Piloted Aircraft System).

Drone and UAV/UAS are commonly used to refer to military uses and RPA/ RPAS to name drones with civilian purposes.

Although drones seem to be a very modern invention and there is no consensus regarding the first use of a drone, it seems that drones started to be used for military purposes. The first patent for a "Method of and apparatus for controlling mechanism of moving vessels or vehicles" was filed by Nikola Tesla in 1898 (Infographic 2016), although it was in 1951 that the first prototypes of Ryan's Q-2C Firebee 
pilotless aircraft were tested. Designed by the company Ryan Aeronautical as a target contract from the North American Air Force, this drone was in production for over 40 years and is still being used by some military organizations (San Diego Air and Space Museum 2017).

Nowadays, different patents are being filed that are as specific as drones without propellers (application number KR20150177849 20151214) or drones capable of operating in an aqueous environment (application number US201614994662 20160113), showing how interesting the industry can be for new companies and new business ideas.

\section{Overview of the Drone Sector}

The use of drones has been growing during the last years, and the two main market segments (military and hobby/leisure) have turned into three, depending on their final uses: military, commercial, and hobby. Figure 1 presents the estimated evolution of the three segments. Although the military segment is the main market by value, the figure indicates that the other two segments will expand during the next years.

Although the use of drones has generated considerable controversy due to privacy and safety awareness, nowadays people's perceptions about "good" uses of drones related to civil uses (commercial and hobby) have changed their image and acceptance (Table 1). Among the accepted uses of unmanned aerial vehicles, we may cite those related to health (transport of blood and defibrillators), humanitarian

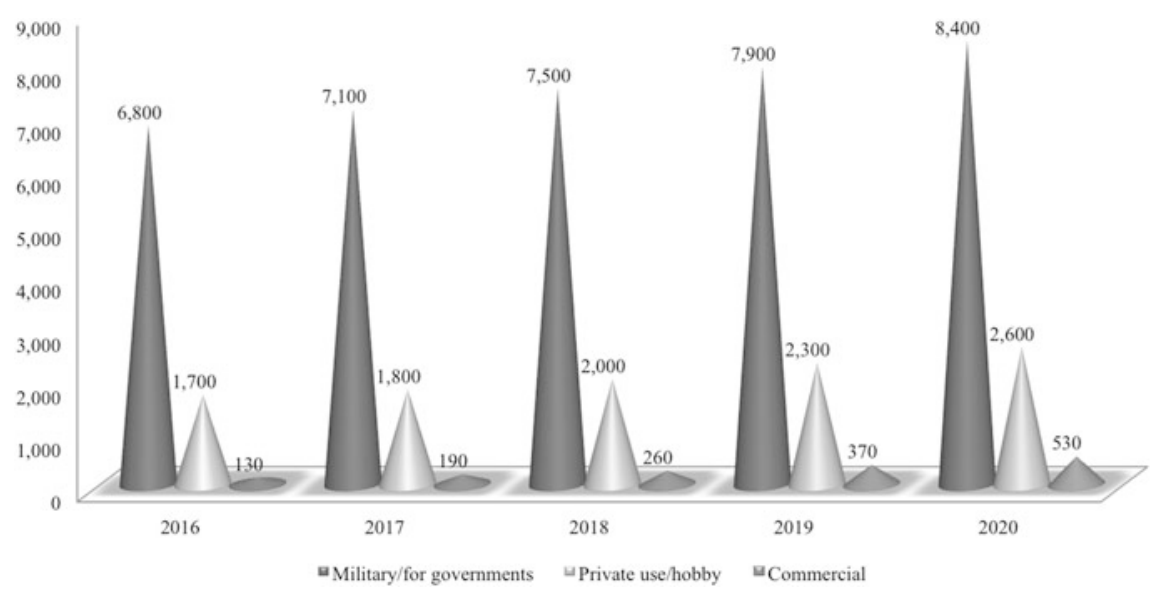

Fig. 1 Estimated value of drone market segments worldwide, 2016-2010 (mill. US\$). Source Own elaboration from data of Moe et al. (2016) 
Table 1 Acceptable drone applications

\begin{tabular}{l|l}
\hline Accepted uses & \\
\hline Source & Use \\
\hline Amukele et al. (2017) & Blood transportation \\
\hline Hardy et al. (2017) & Mapping malaria vector habitats \\
\hline Pulver et al. (2016) & Transporting automated external defibrillators \\
\hline Chabot and Francis (2016) & Bird detection \\
\hline Hodgson et al. (2017) & Surveying marine fauna \\
\hline Sankey et al. (2017) & Forest monitoring \\
\hline Casella et al. (2017) & Mapping coral reefs \\
\hline Szantol et al. (2017) & Mapping orangutan habitat \\
\hline Chowdhury et al. (2017) & Disaster response and relief \\
\hline Restas (2015) & Supporting disaster management (earthquakes, floods, fires) \\
\hline
\end{tabular}

Source Own elaboration from different sources

actions (drones for social goods and humanitarian purposes), shipping products to customers (Amazon's fleet of drones), or ecological applications (surveying fauna and forest monitoring), among others.

However, not only are the applications of drones evolving; the expected revenue increase in the next 10 years is also impressive. According to Tractica (2017c), the greatest evolution will take place in North America, Asia, and Europe, which are also the areas of the market leaders nowadays.

The industry is growing fast, driven mainly by technology. The number of drone-specific exhibitions and conferences is rising (for instance UAV Expo in Brussels or AUVSI's Xponential in the USA), and rapid industry developments are evident. Some examples are drones with robotic arms that can grab objects and magnetic pieces containing drone engines that can be adjusted to objects and turn them into drones (prototypes by Prodrone, a Japanese company). Additionally, though, safety and research are leading the change, and interesting conclusions are being drawn; indeed, the British company Consortiq's CQNet, by collecting and analysing data, defines landing with minimal battery charge as the main reason for the lack of drone safety. The possibilities of the industry are immense, and currently the regulatory barrier (Pauner et al. 2015) seems to be the main impediment to the drone industry taking off definitively (Fig. 2).

Regarding manufacturers, China's DJI followed by the French Parrot occupy the top positions, according to Droneii (2016a), followed by Chinese and North American companies, as reflected in Fig. 3. 


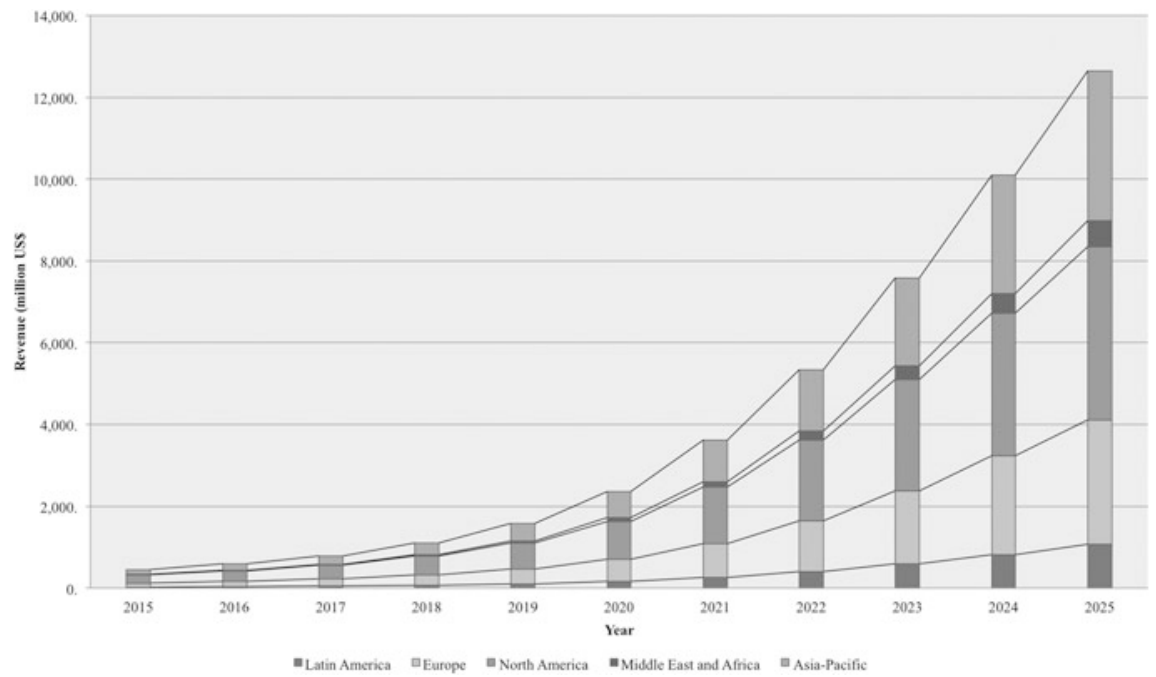

Fig. 2 Projected commercial drone revenue from 2015 to 2025 (in million US dollars). Source Own elaboration from data of Tractica $(2017 \mathrm{c})$

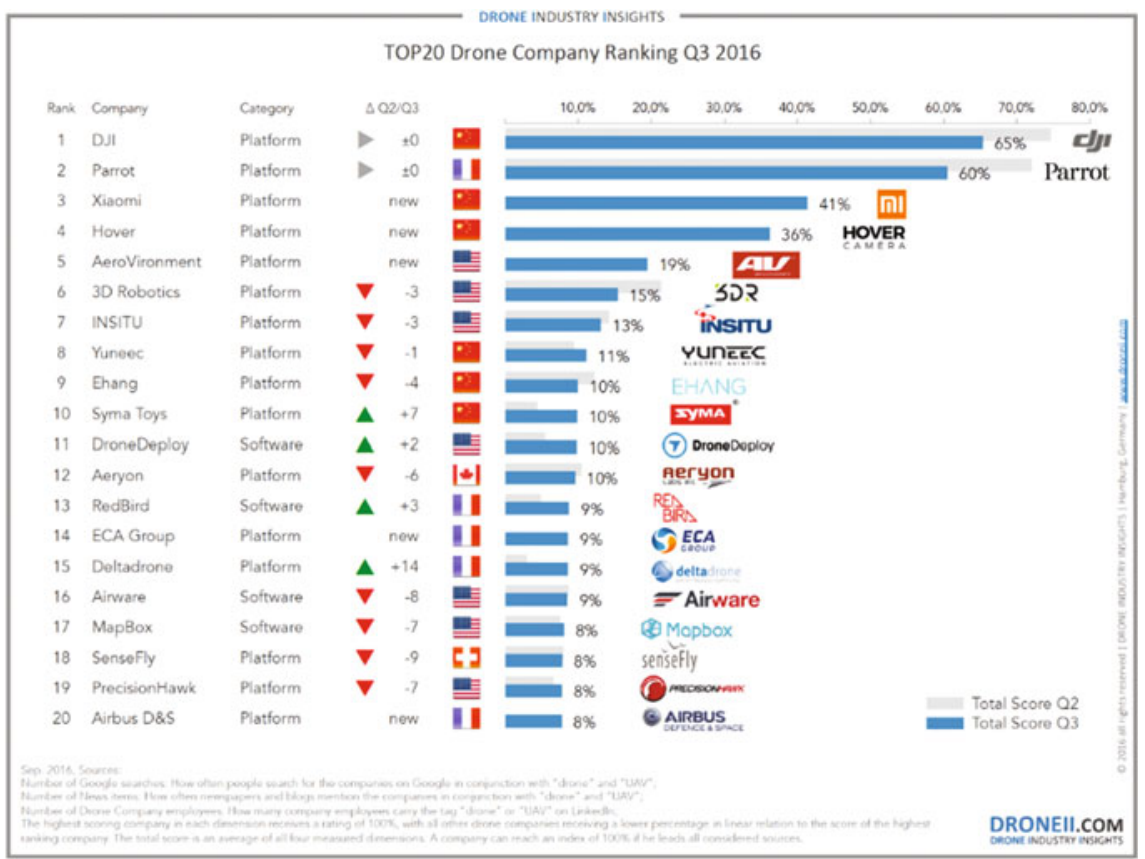

Fig. 3 Drone company ranking, Q3 2016 (Droneii 2016a), with permission of the company (https://www.droneii.com/top20-drone-company-ranking-q3-2016) 


\section{Market Segments}

Segmentation is a market strategy focused on the consumer side, which allows a better fit between products and users' requirements (Smith 1956). A firm that follows a market segmentation strategy is expected to increase its profitability (Wind 1978), although an empirical study is needed. In this study the basic demographic data, such as customer characteristics, users' needs, final use, and so on, are necessary to determine the different existing segments. This goal of this study is to identify and classify the market segments or "sets of buyers" that indeed will be the industry's target groups and will define companies' marketing strategies (Venter et al. 2015).

Markets for drones tend to be segmented in relation to their use, which also corresponds to price ranges. Generally, the sector is structured in three groups: military, commercial, and hobby. For our analysis, however, we have divided the market into five groups (Table 2), which we have defined after taking into consideration the theoretical market segmentation background.

Forecasting undertaken for the industry by the Teal Group (2013) and Tractica (2016, 2017a), among others, predicts future growth for all the market segments. For example, concerning the hobby segment, Tractica (2016) indicates that the revenue worldwide amounted to US\$1865.65 million in the year 2015. Moreover, it estimates that the revenue for this segment will be US\$3528.73 million in 2018 and US\$5031.36 million in 2022. In relation to the military segment, the Teal Group (2013) estimates that the production value worldwide will be US\$2629.1 million in 2015, while it will be US\$4075.4 million in 2018 and US\$8076.4 million in 2022.

Table 2 Market segments for drones

\begin{tabular}{l|l|l|l}
\hline Use & Customer target & Price (€) & Example of drones \\
\hline Group 1-Toys & Children & 49.95 & X_DRONE_ATOM_221 \\
\hline Group 2-Hobby & Young people and adults & 179.99 & Cheerson CX 20 \\
\hline Group 3-Professional & $\begin{array}{l}\text { Professionals (for aerial } \\
\text { filming and photography } \\
\text { services) }\end{array}$ & $\begin{array}{l}4875 \\
549\end{array}$ & $\begin{array}{l}\text { DJI Inspire 1 Pro } \\
\text { Parrot BEBOP 2 FPV }\end{array}$ \\
\hline Group 4-Commercial & $\begin{array}{l}\text { Companies in industries such } \\
\text { as agriculture, media, mining, } \\
\text { energy, construction, etc. }\end{array}$ & $\begin{array}{l}19,921.2 \\
10,172.5\end{array}$ & $\begin{array}{l}\text { Altura Zenith } \\
\text { (Aerialtronics) } \\
\text { Alta 6 (Freefly) }\end{array}$ \\
\hline Group 5-Military & Governments & $\begin{array}{l}\text { Not } \\
\text { available }\end{array}$ & RQ-2A Pioneer \\
\hline
\end{tabular}

Sources Teal Group (2013), Tractica (2016, 2017a), and own elaboration through an analysis of the companies in the sector 
The use of drones for commercial purposes in outdoor environments has increased in recent years, and this tendency will continue in the future. Their use for commercial purposes means their use in sectors such as infrastructure, transport, insurance, media and entertainment, telecommunications, agriculture, security, and mining (PwC 2016). Tractica (2017c) indicates that the worldwide revenue for commercial drones was US\$452.43 million in the year 2015 . It estimates that the revenue will be US\$1110.59 million in 2018 and US\$5334.68 million in 2022.

Figure 4 shows that the highest estimated growth in the next years will occur in the commercial segment; that is, companies in other industries will demand more drones for monitoring activities, mapping, and surveying (Narkus-Kramer 2017). In the future more industries will probably find new applications for drones that the current technology does not allow; then drone manufacturers will offer these features in their products (Ott 2012). Movement to the commercial segments can be detected nowadays in companies such as DJI, which has started to partner with other companies to offer drones with software specializing in agriculture, mining, and construction.

Focusing on the European market, Table 3 might explain why companies are interested in the drone industry and are developing specific software for drones. The turnover data show that the highest values are for energy, construction, agriculture, real estate, and transport. However, if we consider turnover by firm, interesting markets for drone manufacturers will be energy, water and waste, postal and courier activities, telecommunication, and mining. All these sectors are currently target markets for drone manufacturers.

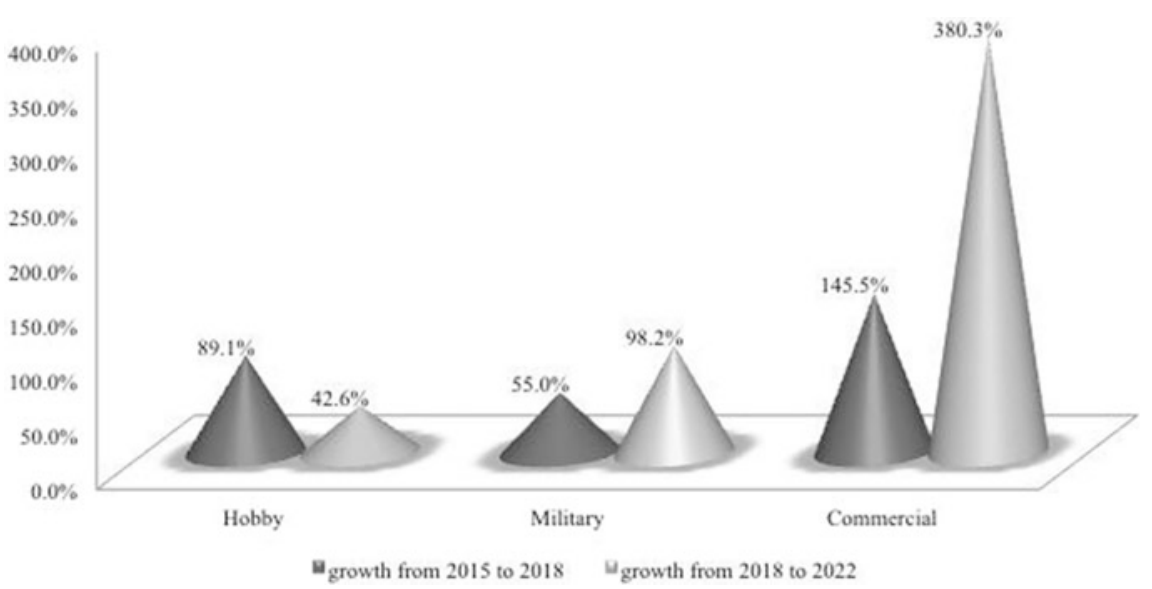

Fig. 4 Estimated growth for segments in the next years. Source Own elaboration from data of the Teal Group (2013) and Tractica (2016, 2017c) 
Table 3 European data related to industries in which outdoor drones can be used (EU 20 countries 2014)

\begin{tabular}{|c|c|c|c|c|}
\hline Sector & $\begin{array}{l}\text { Number of } \\
\text { firms }\end{array}$ & Turnover $^{\mathrm{a}}$ & $\begin{array}{l}\text { Largest } \\
\text { number of } \\
\text { firms }\end{array}$ & $\begin{array}{l}\text { Largest } \\
\text { turnover }\end{array}$ \\
\hline $\begin{array}{l}\text { Electricity, gas, steam, } \\
\text { and air conditioning } \\
\text { supply }\end{array}$ & 87,465 & $1,478,875.8$ & $\begin{array}{l}\text { France, Spain, } \\
\text { Italy, Czech } \\
\text { Republic }\end{array}$ & $\begin{array}{l}\text { Germany, } \\
\text { Italy, United } \\
\text { Kingdom, } \\
\text { France }\end{array}$ \\
\hline $\begin{array}{l}\text { Water supply; sewerage, } \\
\text { waste management, and } \\
\text { remediation activities }\end{array}$ & 75,738 & $253,000.0$ & $\begin{array}{l}\text { France, Italy, } \\
\text { Poland }\end{array}$ & $\begin{array}{l}\text { Germany, } \\
\text { United } \\
\text { Kingdom, } \\
\text { France, Italy }\end{array}$ \\
\hline Construction & $3,441,304$ & $1,577,430.1$ & $\begin{array}{l}\text { France, Italy, } \\
\text { Spain, } \\
\text { Germany, } \\
\text { United } \\
\text { Kingdom }\end{array}$ & $\begin{array}{l}\text { France, } \\
\text { United } \\
\text { Kingdom, } \\
\text { Germany, } \\
\text { Italy } \\
\end{array}$ \\
\hline $\begin{array}{l}\text { Land transport and } \\
\text { transport via pipelines }\end{array}$ & 916,520 & $530,000.0$ & $\begin{array}{l}\text { Spain, Poland, } \\
\text { Italy, France }\end{array}$ & $\begin{array}{l}\text { Germany, } \\
\text { France, } \\
\text { United } \\
\text { Kingdom, } \\
\text { Italy } \\
\end{array}$ \\
\hline $\begin{array}{l}\text { Postal and courier } \\
\text { activities }\end{array}$ & 65,800 & $110,000.0$ & $\begin{array}{l}\text { United } \\
\text { Kingdom, } \\
\text { Germany, } \\
\text { Netherlands, } \\
\text { Spain } \\
\end{array}$ & $\begin{array}{l}\text { Germany, } \\
\text { United } \\
\text { Kingdom, } \\
\text { France }\end{array}$ \\
\hline Insurance & n.a. & n.a. & $\begin{array}{l}\text { Germany, } \\
\text { France, Spain }\end{array}$ & $\begin{array}{l}\text { Germany, } \\
\text { France, Italy }\end{array}$ \\
\hline $\begin{array}{l}\text { Motion picture, video, } \\
\text { and TV programme } \\
\text { production; sound } \\
\text { recording and music } \\
\text { publishing activities }\end{array}$ & 138,246 & $70,573.2$ & $\begin{array}{l}\text { France, United } \\
\text { Kingdom, } \\
\text { Netherlands, } \\
\text { Sweden, } \\
\text { Germany } \\
\end{array}$ & $\begin{array}{l}\text { United } \\
\text { Kingdom, } \\
\text { France, } \\
\text { Germany }\end{array}$ \\
\hline $\begin{array}{l}\text { Advertising and market } \\
\text { research }\end{array}$ & 300,440 & $160,000.0$ & $\begin{array}{l}\text { Netherlands, } \\
\text { Germany, } \\
\text { France, Spain }\end{array}$ & \begin{tabular}{|l|} 
United \\
Kingdom, \\
Germany, \\
France \\
\end{tabular} \\
\hline Telecommunication & 45,377 & $378,000.0$ & $\begin{array}{l}\text { United } \\
\text { Kingdom, } \\
\text { Poland, France, } \\
\text { Spain, Italy }\end{array}$ & $\begin{array}{l}\text { United } \\
\text { Kingdom, } \\
\text { France, } \\
\text { Germany } \\
\end{array}$ \\
\hline Agriculture & $178,126.54^{\mathrm{b}}$ & $418,713.55^{\mathrm{c}}$ & $\begin{array}{l}\text { France, Spain, } \\
\text { United } \\
\text { Kingdom, } \\
\text { Germany }\end{array}$ & $\begin{array}{l}\text { France, } \\
\text { Germany, } \\
\text { Italy, Spain, } \\
\text { United } \\
\text { Kingdom } \\
\end{array}$ \\
\hline
\end{tabular}


Table 3 (continued)

\begin{tabular}{|c|c|c|c|c|}
\hline Sector & $\begin{array}{l}\text { Number of } \\
\text { firms }\end{array}$ & Turnover $^{\mathrm{a}}$ & $\begin{array}{l}\text { Largest } \\
\text { number of } \\
\text { firms }\end{array}$ & $\begin{array}{l}\text { Largest } \\
\text { turnover }\end{array}$ \\
\hline $\begin{array}{l}\text { Security and } \\
\text { investigation activities }\end{array}$ & 56,000 & $46,000.0$ & $\begin{array}{l}\text { France, United } \\
\text { Kingdom, } \\
\text { Hungary, } \\
\text { Germany }\end{array}$ & $\begin{array}{l}\text { United } \\
\text { Kingdom, } \\
\text { France, } \\
\text { Germany }\end{array}$ \\
\hline Mining and quarrying & 19,237 & $223,983.5$ & $\begin{array}{l}\text { Italy, } \\
\text { Germany, } \\
\text { Spain, France, } \\
\text { Poland, } \\
\text { Romania, } \\
\text { Portugal }\end{array}$ & $\begin{array}{l}\text { Norway, } \\
\text { Italy, United } \\
\text { Kingdom, } \\
\text { Netherlands }\end{array}$ \\
\hline $\begin{array}{l}\text { Architectural and } \\
\text { engineering activities; } \\
\text { technical testing and } \\
\text { analysis }\end{array}$ & $1,005,668$ & $329,000.0$ & $\begin{array}{l}\text { Italy, } \\
\text { Germany, } \\
\text { France, Spain, } \\
\text { United } \\
\text { Kingdom }\end{array}$ & $\begin{array}{l}\text { United } \\
\text { Kingdom, } \\
\text { Germany, } \\
\text { France }\end{array}$ \\
\hline Real estate activities & $1,369,456$ & $484,231.4$ & $\begin{array}{l}\text { Germany, } \\
\text { Italy, France, } \\
\text { Spain }\end{array}$ & $\begin{array}{l}\text { Germany, } \\
\text { France, } \\
\text { United } \\
\text { Kingdom }\end{array}$ \\
\hline
\end{tabular}

Source Eurostat

${ }^{\mathrm{a}}$ Millions €

${ }^{\mathrm{b}}$ Utilized agricultural area (thousands of hectares)

${ }^{\mathrm{c}}$ Output of the agricultural industry at basic prices (after taxes but including subsidies; million €)

\section{Main Competitors in the Sector}

Competitors in the drone sector operate globally, and this environment increases the rivalry in the market. To obtain a list of competitors in the industry, we used different lists obtained from sources specialized in the field (PwC 2016; Droneii 2016a) and a statistical database (Statista).

Through the analysis of the information on the web pages of the companies in these lists, including the products offered by the companies and their prices, we have organized the competitors using the same groups of markets as defined in Sect. 2. Therefore, we have established five groups of competitors depending on the market segment in which they sell their products (Tables 4, 5, 6, 7, 8):

- Group 1: manufacturers offering drones to consumer markets as toys,

- Group 2: manufacturers offering drones to consumer markets as hobby products,

- Group 3: manufacturers offering drones for professional purposes,

- Group 4: manufacturers offering drones for specific industries,

- Group 5: manufacturers offering military drones. 


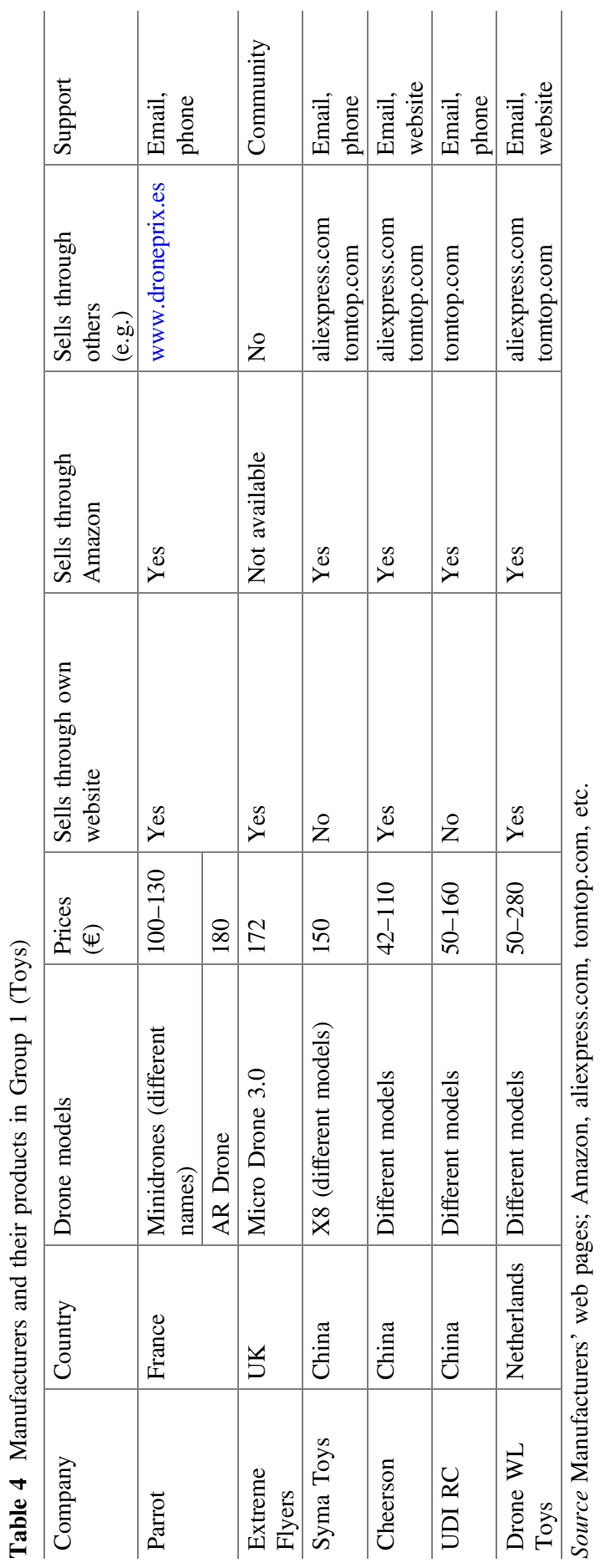




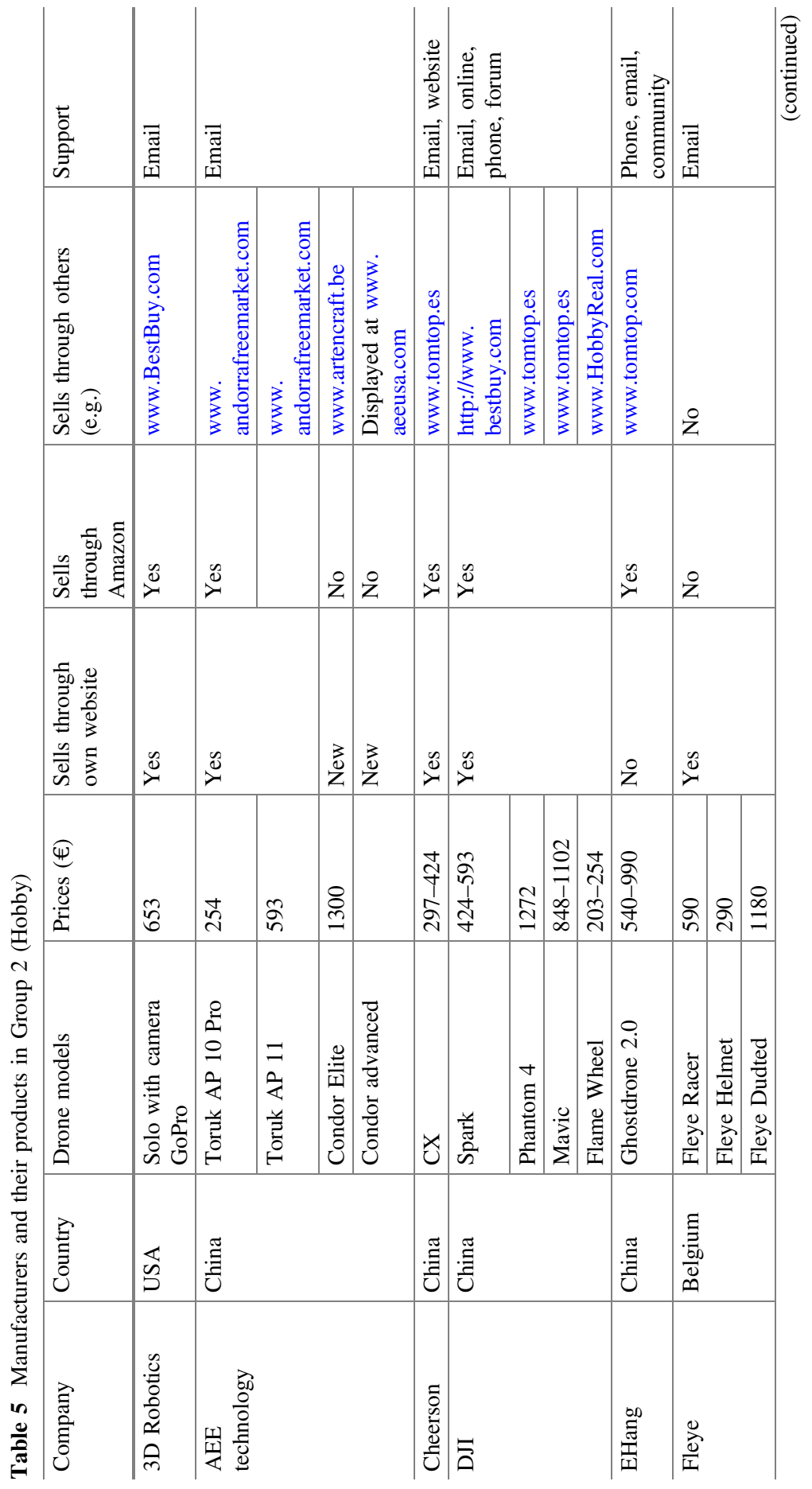




\begin{tabular}{|c|c|c|c|c|c|c|c|c|c|c|c|c|c|c|c|}
\hline 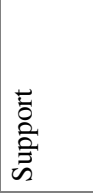 & $\begin{array}{l}\overline{\tilde{J}} \\
\overline{0} \\
\dot{0} \\
\tilde{\Xi} \\
\bar{D}\end{array}$ & 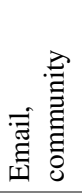 & 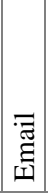 & 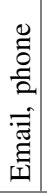 & $\begin{array}{l}\frac{0}{6} \\
\frac{0}{0} \\
\frac{0}{30} \\
3\end{array}$ & 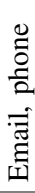 & 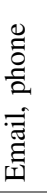 & & 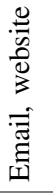 & 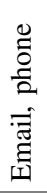 & 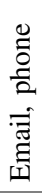 & & & & \\
\hline 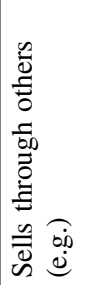 & 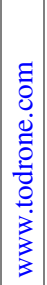 & 之o & 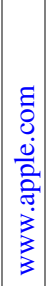 & 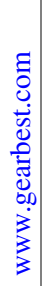 & $\stackrel{\circ}{z}$ & 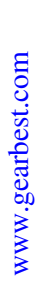 & 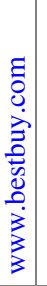 & 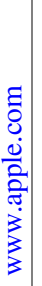 & 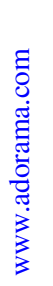 & 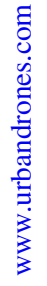 & 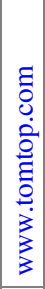 & 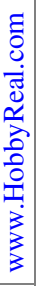 & 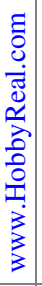 & 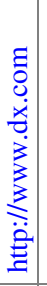 & 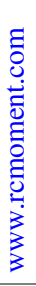 \\
\hline
\end{tabular}

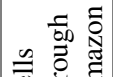

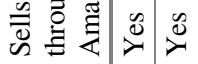

$そ)$

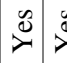

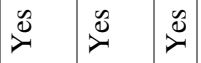

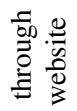

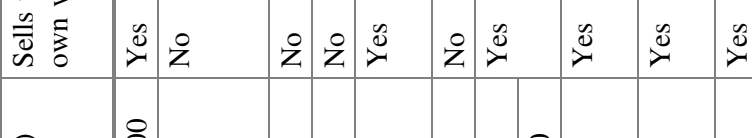

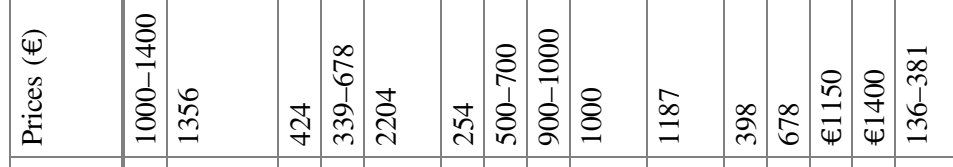

\begin{tabular}{|c|c|c|c|c|c|c|c|c|c|c|}
\hline 志 & 岕 & 㞼 & : & $\stackrel{\stackrel{\Xi}{\Xi}}{\stackrel{\Xi}{\Xi}}$ & 氐 & 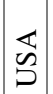 & 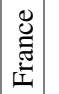 & 死 & 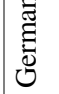 & 解 \\
\hline 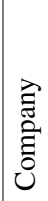 & $\begin{array}{l}\circ \\
0 \\
0 \\
0\end{array}$ & 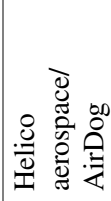 & 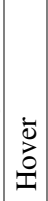 & 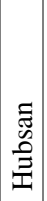 & 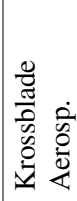 & 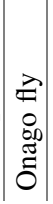 & : & 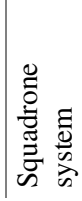 & 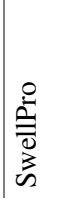 & 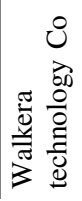 \\
\hline
\end{tabular}




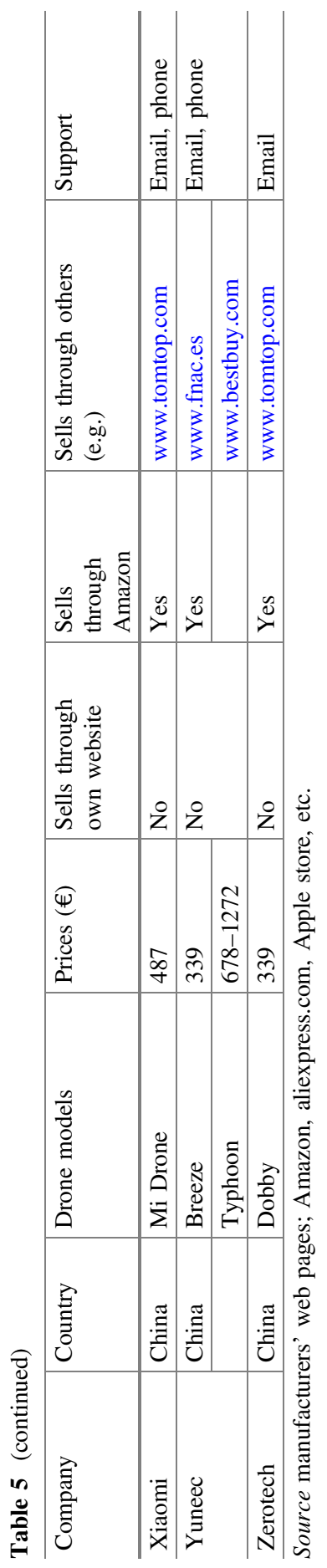




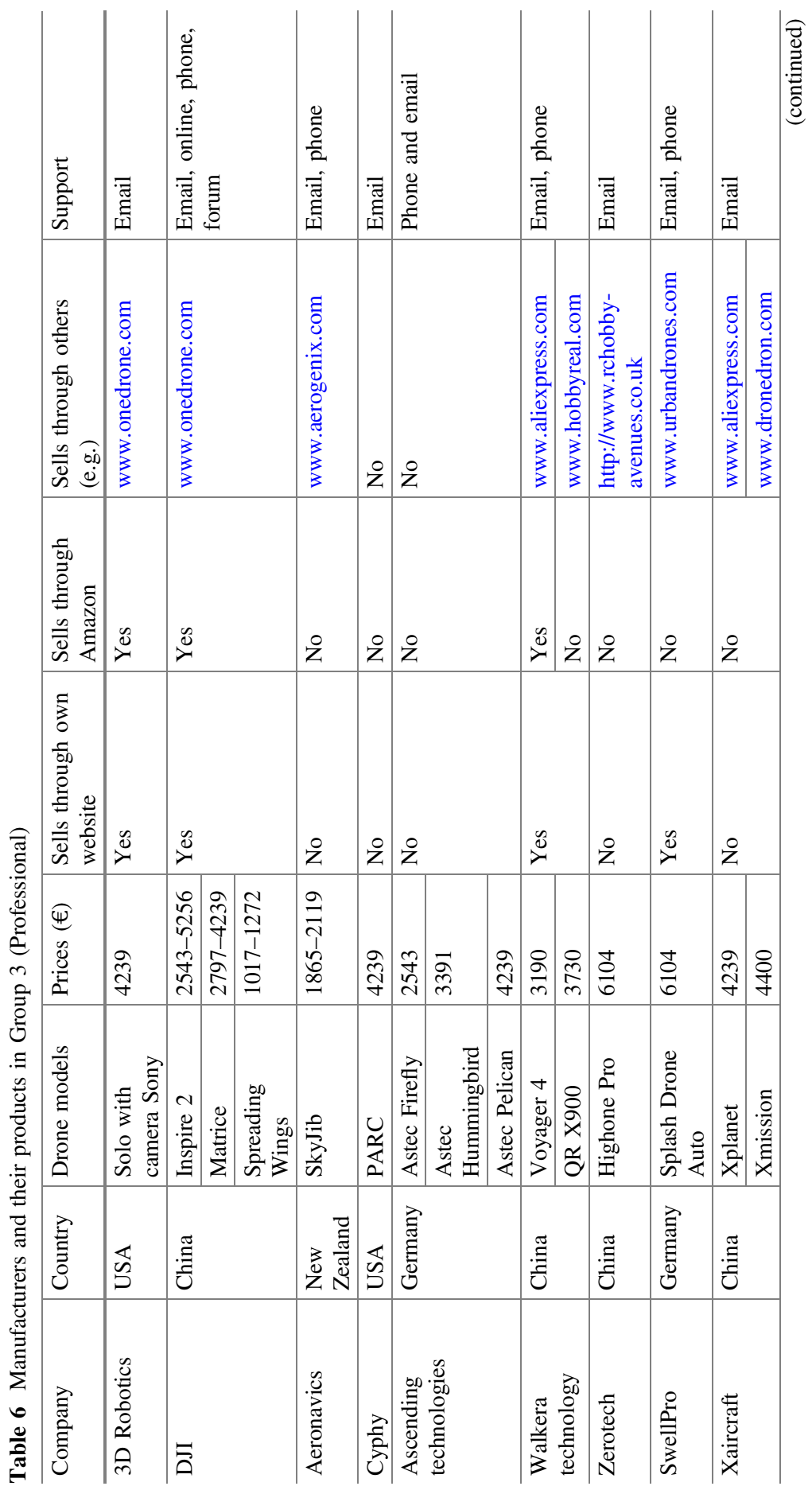




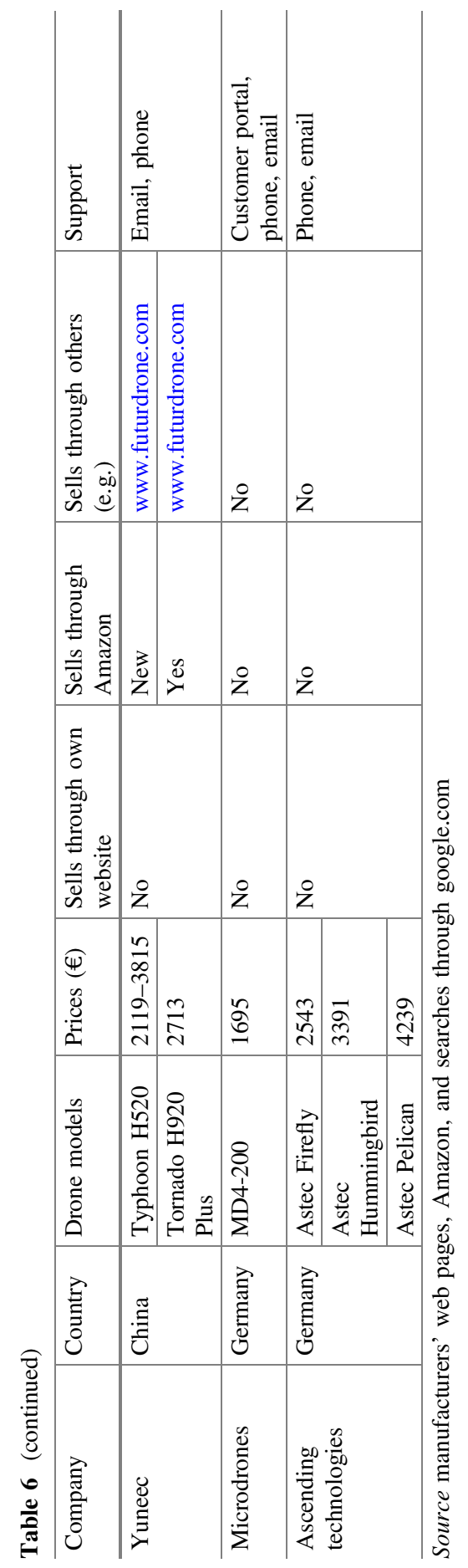




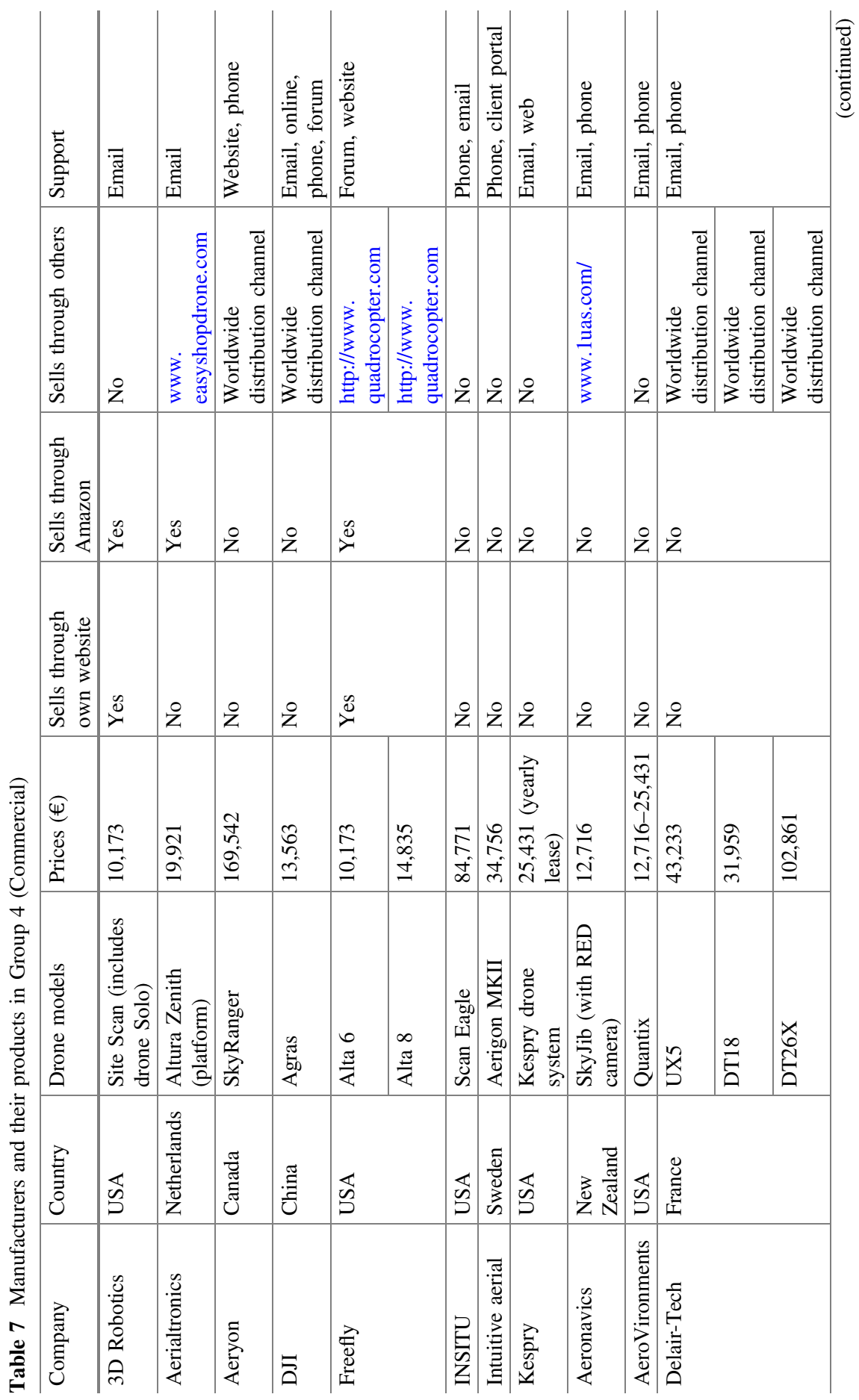




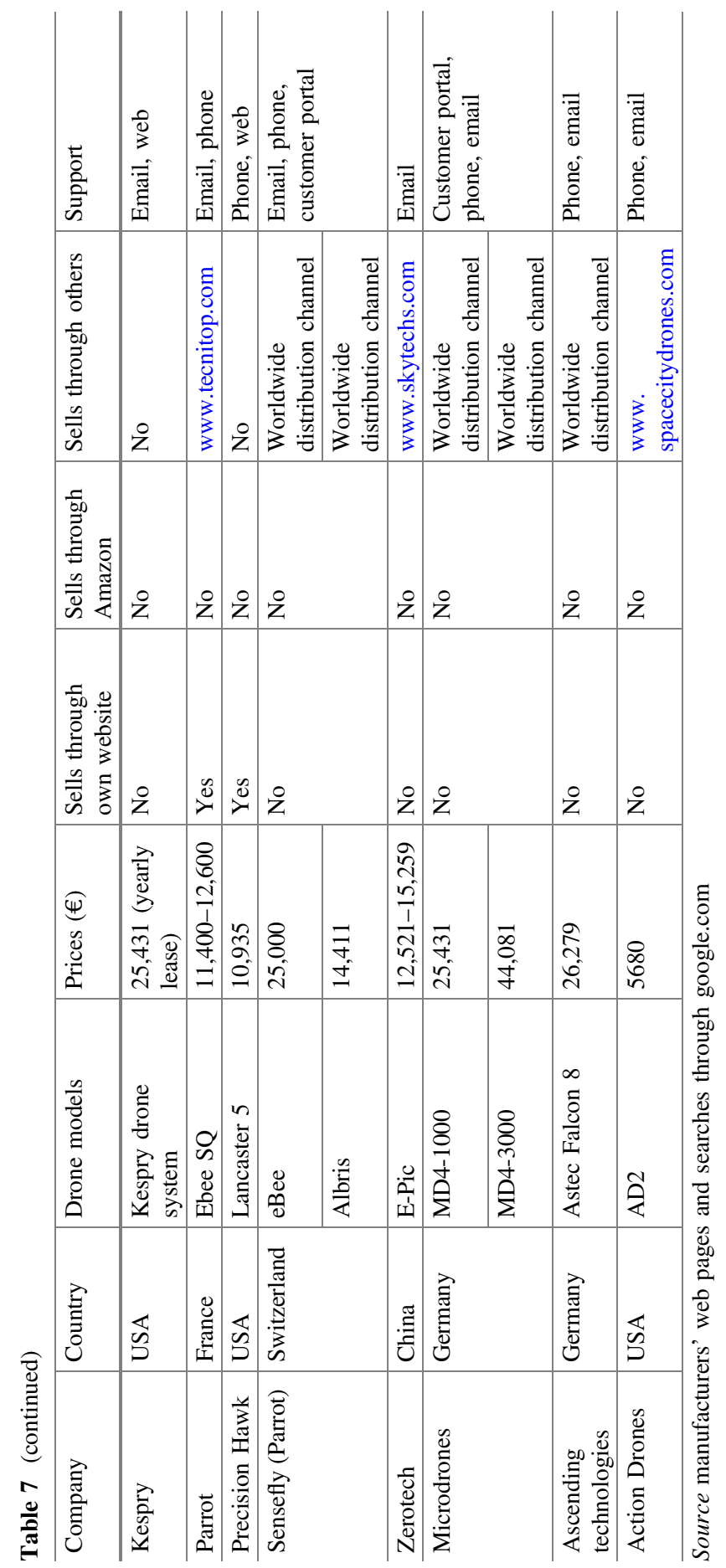


Group 1 (Toys) includes manufacturers of drones of which the customer target is children, who will have their first experience of flying drones. Table 4 presents some examples of the companies included in this group, indicating that the prices are around $€ 100$ and that some models carry a camera while others do not. Companies use external selling channels, such as Amazon, to reach their customers. European manufacturers in this group have to compete with Chinese firms.

Group 2 (Hobby) involves manufacturers of products that are focused on different customers from Group 1, who want to film themselves and their relatives and/ or friends while participating in action sports or other activities. Taking into account the higher purchase capacity of customers in this group, drones will include more technical features than those in Group 1. These features might include a camera and storage function (e.g. Micro-SD card or similar). These recreational customers are also looking for customizable and programmable features, ease of use, durability, and flight time. They are willing to pay between $€ 500$ and $€ 1500$ for drones included in Group 2, and they buy them directly from the manufacturer's website, through Amazon, and through other dealers, such as www.aliexpress.com or www. tomtop.com (Table 5). This group seems to be more profitable considering the number of companies involved in it. However, companies have to compete with an important rival, the Chinese firm DJI.

Group 3 (Professional) includes manufacturers of drones for professional filming and photography. Drone operators whose main activity is aerial filming services use these types of products, which are sometimes high models of those shown in Group 2. The prices are below €10,000, and DJI is an important rival. This company is very active in partnering with other firms for both hardware and software. Nowadays, DJI competes with firms that offer drones with cameras (Inspire 2, Phantom 4 Pro) and with those that offer drone platforms to carry different cameras (Matrice 600 Pro, Spreading Wings S1000 +). It is difficult for smaller companies to offer both products, so they need to choose between them. Offering a platform without a camera would allow customers to fit the drone with professional cameras, such as RED and Alexa, with a higher final cost for the user. These cameras are heavy and need bigger drones with the capacity to fly with a heavy camera.

Group 4 (Commercial) involves manufacturers that develop solutions for specific industries. The value of the offering is based more on the software and applications than on the drone itself. Companies partner (Droneii 2016b) with software firms (Airmap, Facebook), hardware firms (Intel, Leica Geosystems), and cameras makers (Sony) in an effort to increase the value associated with their products. As a result, the final price of the solution, which includes a drone, is higher. Moreover, some drone manufacturers offer the software with a yearly fee license (Kespry), following the rules from the software industry. Group 4 also includes companies that offer services through a drone instead of selling it. The company designs and assembles the drone, but its business model is built on offering services related to drones as its value proposition. Therefore, Group 4 includes companies offering only the product (drone and software), the product and services, and only services. 


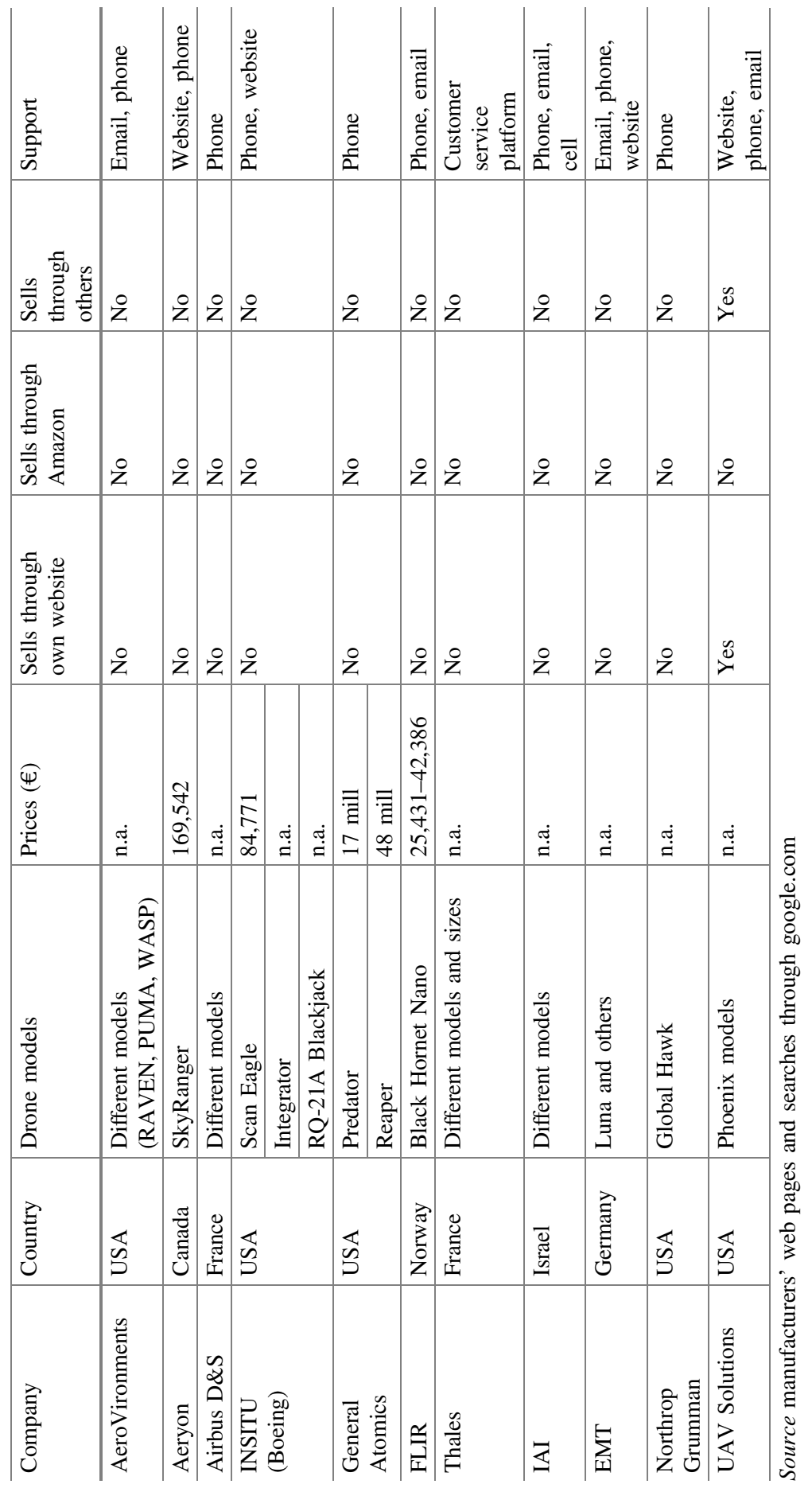


Few companies in Group 4 sell through their own online shop. Table 7 indicates that these companies are the ones with lower prices. The rest of the firms tend to sell directly to customers or use specialized dealers.

Group 5 (Military) includes manufacturers focused on defence and military purposes. They sell to armies, governments, and defence organizations like NATO (North Atlantic Treaty Organization). Companies need to fulfil the requirements specified by each government in security assurance relations. Some companies have started to offer products to customers in Group 4, as some of their products can be used for surveillance and monitoring. This might indicate their interest in the increase in the commercial market and the capacity of some of these industries to assume higher costs in buying drones and the services associated with them. Military companies have skilled resources and technologies that can be used for different purposes.

The software incorporated into drones has been demonstrated to be an importance source of value creation. This has produced parallel growth in companies focused on software development. Among these companies are Airware (USA), Dedrone (Germany), DroneDeploy (USA), MapBox (USA), PIX4D (Switzerland), RedBird (France), SkyWards (USA), and Skyworks Aerial System (USA). Most companies are from the United States and others are from European countries, outlining the drone industry. Some solutions allow the processing and analysis of data from images captured through drones, adapting their solutions to different industries (mining, agriculture, surveying, construction, etc.). Other companies work as developers of drone detection (Dedrone), flying simulators (Redbird), and platforms that publish data obtained through other drone software (MapBox).

The main conclusions that we could obtain from the analysis of the competitors are the following:

(a) As shown by the number of companies that enter the drone market every year, there are no high barriers to entry.

(b) Companies have started to extend their customer segments, especially the biggest companies in the sector. This can be observed in DJI, 3D Robotics, and Parrot, but also in some companies operating in both the commercial and the military segment.

(c) Camera makers and software developers are strategic partners for drone companies. For example, big companies use cameras and software to offer products with a higher value and adapt them to each segment. The final cost of the solutions will increase with these additional features. Increasingly these customers pay for the software included as an annual fee.

(d) New features spread rapidly through the industry (incremental innovations such as extended flight time, better cameras, less noise, auto charging batteries, etc.).

(e) The high number of competitors in the market might explain why they offer more than one selling channel for their products, although this is less usual for higher-priced drones (the military segment and some commercial solutions). 
(f) While companies are selling lower-priced drones online, higher-priced drones are usually sold directly after contact by email or through a worldwide distribution channel.

(g) The main support is obtained by users through channels including phone, email, and web pages.

(h) The price of military drones is not readily available and might depend strongly on the amount ordered, extra features, and the strategic point of view.

\section{Main European Figures}

Tractica's (2017b) data indicate that the revenue from commercial drones in Europe in 2015 was US\$99.53 million. Moreover, they estimate important growth in revenue from 2016 to 2025 . They forecast US $\$ 250.99$ million in revenues for 2018 , US\$1248.32 million for 2022, and US\$3035.33 million for 2025. Figure 5 presents these data in percentages, showing the highest growth period as 2018-2022. In terms of units, the current use of drones in Europe (SESAR 2016) is limited to around 1000 military drones, 1-1.5 million consumer drones, and 10,000 units of commercial drones. SESAR (2016) forecasts 200,000 units in 2025 and 395,000 in 2035 for the commercial domain, agriculture being the main domain with 150,000 units in 2035. Other important domains are energy (10,000 units), public safety and security (60,000), e-commerce and delivery (70,000), mobility and transport (1000), and others (media, mining and construction, insurance, real estate, telecommunication, and academic research) with 100,000 units in 2035. On the other hand, the main opportunities in the sector will be associated with service activities (related to software, data, and flying operations), which will absorb $80 \%$ of the total economic impact in 2035 (SESAR 2016).

Table 9 shows the location of drone companies in Europe and indicates that the main countries are the United Kingdom, Italy, Germany, and France. The importance of these countries is also clear when data about international trade and the number of operators registered are exposed. International trade data indicate that the country that imports the most drones is the United Kingdom, followed by India, Italy, Azerbaijan, Germany, Turkey, France, Singapore, and Brazil (The Guardian 2015a). On the other hand, the main exporting countries of drones are Israel, the United States, Canada, Russia, France, Austria, Italy, Germany, and China (The Guardian 2015b). Other sources include Spain and Switzerland among the important countries in the European drone market (Wichmann 2017). Tables 4, 5, 6, 7, 8 present the European manufacturers in each of the five segments analysed, and they included some of these countries. The leading European (Government Office for Science 2017) RPAS manufacturers are Parrot (France), AirRobot (Germany), Ascending Technologies (Germany), MicroDrones (Germany), UAV Factory (Latvia), and Aerialtronics (Netherlands).

Data about the number of drone operators certified are published by the aviation authorities of each country, although these data are not always available, because in 


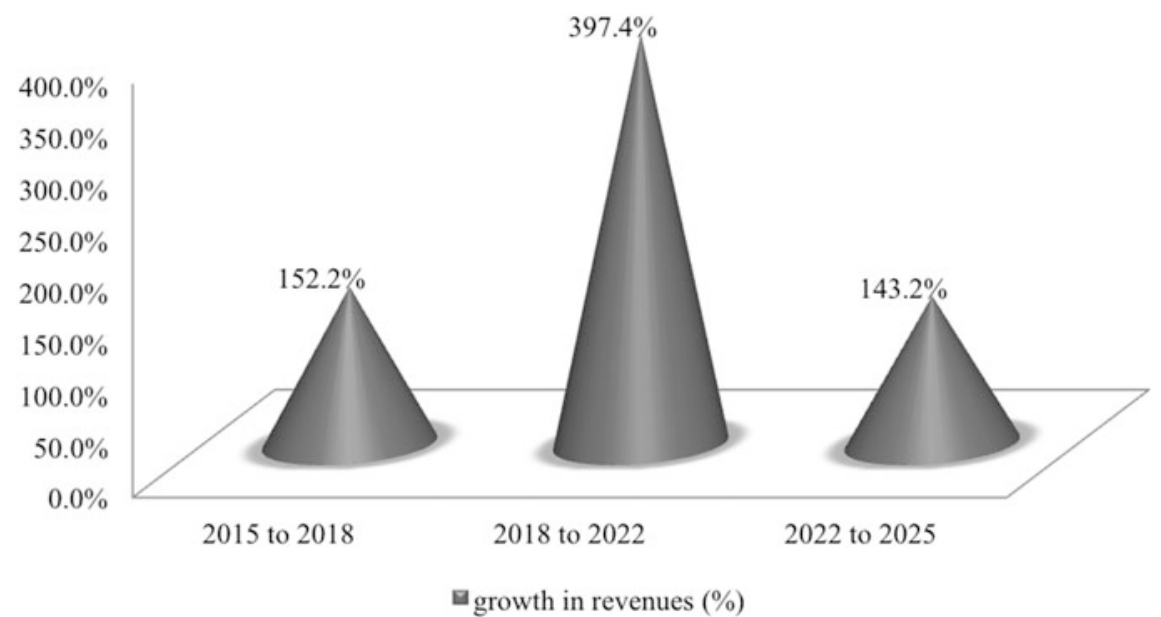

Fig. 5 Estimated growth in revenues for commercial drones in Europe. Source Own elaboration from data of Tractica (2017b)

Table 9 Drone manufacturers by European country in relation to important manufacturers' countries

\begin{tabular}{l|l|l|l}
\hline Country & $\begin{array}{l}\text { Number of } \\
\text { manufacturers }\end{array}$ & Country & $\begin{array}{l}\text { Number of } \\
\text { manufacturers }\end{array}$ \\
\hline USA & 229 & Israel, Spain & 16 \\
\hline China & 38 & Australia & 15 \\
\hline UK & 34 & $\begin{array}{l}\text { Austria, Netherlands, Sweden, } \\
\text { Switzerland }\end{array}$ & 8 \\
\hline Italy & 31 & Portugal, Romania, Slovenia, Ukraine & 4 \\
\hline Germany & 30 & $\begin{array}{l}\text { Belarus, Belgium, Bulgaria, Czech } \\
\text { Republic, Finland, Serbia }\end{array}$ & 3 \\
\hline France & 28 & Estonia, Hungary, Latvia & 2 \\
\hline $\begin{array}{l}\text { Canada, } \\
\text { Russia }\end{array}$ & 20 & Denmark, Greece, Ireland, Luxembourg & 1 \\
\hline
\end{tabular}

Source AUVSI (2016)

some countries, such as Germany, there is no registration of drone operators. Table 10 presents the number of licensed operators for some countries. This number has increased in the last years and is continuing to grow, indicating the attraction to this market of new professionals and companies. The activities carried out by these professionals and companies differ by country. For example, in Spain (Todrone 2016) the main activities using drones undertaken by companies and RPAS operators are audiovisual/leisure (45.8\%), infrastructure/mining (16.9\%), and agriculture/environment (14.5\%). In the United Kingdom (Government Office for Science 2017), however, the main activities are aerial photography/video, surveying/mapping, aerial cinematography, and industrial inspection. 
Table 10 Certified drone operators by country

\begin{tabular}{l|l|l}
\hline Country & Operators & Source \\
\hline United Kingdom & 3046 & Civil Aviation Authority (2017) \\
\hline Ireland & 172 & IAA (2017) \\
\hline France & 2250 & Statista (2016) \\
\hline Spain & 2420 & AESA (2017) \\
\hline Italy & 972 & ENAC (2017) \\
\hline Germany & n.a. & n.a. \\
\hline Switzerland & n.a. & n.a. \\
\hline Belgium & 152 & www.beuas.be/fr/membership/licentie \\
\hline
\end{tabular}

Source different sources (n.a.: not available)

\section{Conclusions}

In this chapter the available information regarding the drone industry has been compiled and analysed. Despite the sector having both technological and economic importance, there are important barriers preventing its expansion. The biggest barrier to the industry's development is regulation, which limits the use of drones based mainly on two different reasons: safety and security/privacy. Europe has to resolve this issue as quickly as possible, before the other two big economic countries, the USA and China, achieve advances that are too great compared with those of European firms, leading to an increased gap in academic, technological, business, and social development areas.

Although the first drones were produced in 1951 and the first document regarding unpiloted aircraft was patented in 1898, the main evolution of the drone industry has occurred in recent years, led mainly by military needs. Nowadays the most innovative drone uses can be associated with collaboration (health and drugs delivery, emergency surveillance, security, etc.) and commercial efficiency (agriculture, topography, etc.).

It is important to distinguish among the different segments within the drone industry, since the needs and characteristics of different end users are distinct and therefore the strategic considerations should be addressed separately. In this chapter five different segments have been identified:

- Toys, for which the final customers are children or young people and the use is educational.

- Hobby/leisure, for which the final customers are young people and adults for recreational uses.

- Professional, for which the final customers are drone pilots and the uses are aerial filming and photography services.

- Commercial, for which the final customers are companies and the uses are agriculture, media, mining, energy, or construction activities.

- Military purposes (vigilance, combat, etc.), for which governments are the end customers. 
These segments differ significantly. The price ranges vary widely as well as the basic drone characteristics, like drones with/without a camera, camera quality, flight stability requirements, flight time, data transmission, and so on, so the competitive analysis of the segments must be conducted separately.

Regarding the toy drone subsector, the price is the decisive feature, while quality and technology are not so important. In this segment European companies (mainly from France, UK and the Netherlands) coexist with Chinese ones, whereas North American ones are not represented. Chinese companies offer the cheapest drones (although the French company Parrot offers a minidrone for 30 euros) and have the widest distribution network (not only Amazon but also Aliexpress, which is the most recognized Chinese online seller). To sum up, the companies in this segment follow a cost-based strategy, and Chinese companies seem to have more options. Only by offering distinctive features (for example educational) or additional services (such as competitions for children and young people) can European companies play a role.

The second segment, which we called "hobby", seems to be more interesting for European companies, as quality, reliability, and technology play an important role in the final buying decision. The prices are higher (500-1000 euros); however, although they are important, the prices are not the primary aspect that final users consider when making their buying decision. Technology development (for example allowing the drone to follow you automatically when playing sport, associating with healthy applications, connecting to the usual devices, such as mobile phones or computers, to transfer data and images, and improving the safety measures) are the distinctive features that may define the best players in the near future. Chinese companies coexist with North American and European ones, with no clear leader. The distribution channels, technical support, and after-sales support are named as the key aspects, together with keeping in contact with the regulatory level to comply with safety regulations quickly and safely.

The "professional" segment is experiencing vibrant competition among the European, North American, and Chinese manufacturers. Although the market was led by European companies, the Chinese giant DJI is growing fast, along with other companies, such as Walkera, Zerotech, and Yuneec. The importance of pilot training courses, fair attendance, after-sales and technical support, and the software cost will define the subsector in the near future, together with filming/camera quality and ease of use. The regulations heavily constrain the final users, as they face the need for permits and licences and/or geographical restrictions in carrying out their work properly. The final price still differs by $30-40 \%$, but, as the final characteristics are not especially different, this subsector will tend towards homogenization unless clear quality/technological/service characteristics appear.

The commercial segment has a bright future and is currently the most interesting segment in which to compete. The final prices of drones are high, and the regulations do not particularly affect the final uses, as the main activities are carried out in rural areas or in emergency situations. Most of these drones can be adapted to the final use and associated services, as software and support add value to the final product. European and North American companies are definitely the leaders in this group. 
Information regarding the military segment, especially price and distinctive features, is not easy to find. No Chinese company is competing in this segment, and North American and European companies are mainly leading the segment development. The regulations do not affect the development of this segment as heavily, as the defence and civil fields differ in their limits and possibilities. These companies are often targeted directly by governments due to information restrictions, assuring, on one hand, the technological development and, on the other hand, strategic defence and information upgrades.

The easy of entry into the industry and the expansion of the biggest manufacturers, DJI especially, to other segments, is an important threat for companies operating in segments such as professional and commercial. Moreover, this big firm enters the segment with lower prices, forcing the existing companies to reduce their own prices. Companies are also responding to this threat with a value increase of their products, based on their associated software, which has been developed for specific industries (agriculture, mining, etc.). As a consequence, products have become solutions and cooperation between drone manufacturers and software firms has been the trend during the last years. Military companies have also been attracted to the commercial segment, taking advantage of its advanced technology, which can be used in industries other than defence. Despite positive forecasts for the commercial segment in the next two decades, an increase in rivalry might reduce the profitability in the medium term due to the life cycle of the technologies incorporated into the products. Companies will need to adapt their solutions constantly and take care of their customers by supporting them in purchasing, use, and maintenance.

The main difficulty that we faced during the elaboration of this chapter was the lack of statistics related to this sector. The registration of drone operators, including the drones to be operated, would increase the information available for companies, policy makers, and researchers.

\section{References}

Agencia Estatal de Seguridad Aérea (AESA) (2017) Registro de declaración responsable de operador de aeronaves RPA's. www.seguridadaerea.gob.es/lang_castellano/cias_empresas/ trabajos/rpas/default.aspx. Accessed 22 July 2017

Amukele T, Ness PM, Tobian AAR, Boyd J, Street J (2017) Drone transportation of blood products. Transfus Pract 57:582-588

AUVSI (2016) Maker melting point. Unmanned Syst 34(4):14-15

Casella E, Collin A, Harris D, Ferse S, Bejarano S, Parravicini V, Hench JL, Rovere A (2017) Mapping coral reefs using consumer-grade drones and structure from motion photogrammetry techniques. Coral Reefs 36:269-275

Chabot D, Francis CM (2016) Computer automated bird detection and counts in high-resolution aerial images: a review. J Field Ornithol, 87(4):343-359

Chowdhury S, Emelogu A, Marufuzzaman M, Nurre SG, Bian K (2017) Drones for disaster response and relief operations: a continuous approximation model. Int $\mathrm{J}$ Prod Econ $188: 167-184$ 
Civil Aviation Authority (CAA) (2017) Small Unmanned Aircraft (SUA) operators holding a valid CAA permission. http://publicapps.caa.co.uk/docs/33/20170714RptUAVcurrent.pdf. Accessed 21 July 2017

Droneii (2016a) Top 20 drone company ranking Q2 2016, activity and global reach of the Top20 leading hard- and software manufacturer in the drone industry. www.droneii.com. Accessed 19 July 2017

Droneii (2016b) Drone company partnership. https://www.droneii.com/drone-company-partnerships. Accessed 19 July 2017

ENAC (2017) Operatori autorizzati. www.enac.gov.it/La_Regolazione_per_la_Sicurezza/Sistemi_ Aeromobili_a_Pilotaggio_Remoto_\%28Droni\%29/Operatori_SAPR/index.html. Accessed 22 July 2017

Government Office for Science (2017) The UK value stream for remotely piloted civil aircraft systems (RPAS). www.gov.uk/government/publications/value-of-drones-to-the-uk-literaturereview. Accessed 22 July 2017

Hardy A, Makame M, Cross D, Majambere S, Msellem M (2017) Using low-cost drones to map malaria vector habitats. Parasites \& Vectors 10:29

Hodgson A, Peel D, Kelly N (2017) Unmanned aerial vehicles for surveying marine fauna: assessing detection probability. Ecol Appl 27(4):1253-1267

IAA (2017) Drone operators contact list. https://www.iaa.ie/general-aviation/drones/rpas-aerialwork-permission-holders. Accessed 21 July 2017

Infographic (2016) How tesla developed the first drone ever. https://patentyogi.com/nikola-tesla/ tesla-developed-first-drone/. Accessed 17 July 2017

Moe M, Pampoulov L, Jiang L, Franco N, Han S (2016) Eye in the sky. Available via Statista, the statistics portal. www.a2apple.com/eye-in-the-sky/ and https://es.statista.com/estadisticas/ 660906/prevision-del-valor-mundial-de-los-segmentos-de-mercado-de-drones/. Accessed 17 July 2017

Narkus-Kramer M (2017) Future demand and benefits for small unmanned aerial systems (UAS) package delivery. In: 17th AIAA aviation technology, integration, and operations conference, AIAA AVIATION Forum (AIAA 2017-4103)

Ott I (2012) Service robotics: an emergent technology field at the interface between industry and services. Poiesis \& Prax 9(3-4):219-229

Pauner C, Kamara I, Viguri J (2015) Drones. Current challenges and standardisation solutions in the field of privacy and data protection. ITU Kaleidosc: Trust in the Inf Soc (K-2015):1-7

Pulver A, Wei R, Mann C (2016) Locating AED enabled medical drones to enhance cardiac arrest response times. Prehospital Emerg Care 20(3):378-389

PwC (2016) Clarity from above. PwC global report on the commercial applications of drone technology. https://www.pwc.pl/pl/pdf/clarity-from-above-pwc.pdf. Accessed 29 June 2017

Restas A (2015) Drone applications for supporting disaster management. World J Eng Technol 3 (3):316

San Diego Air and Space Museum (2017) http://sandiegoairandspace.org/hall-of-fame/honoree/t.claude-ryan. Accessed 17 July 2017

Sankey T, Donager J, McVay J, Sankey JB (2017) UAV lidar and hyperspectral fusion for forest monitoring in the southwestern USA. Remote Sens Environ 195:30-43

SESAR Joint Undertaking (2016) European drones outlook study. Unlocking the value for Europe. www.sesarju.eu/sites/default/files/documents/reports/European_Drones_Outlook_Study_2016. pdf. Accessed 19 July 2017

Smith WR (1956) Product differentiation and market segmentation as alternative marketing strategies. J Mark 21(1):3-8

Statista (2016) Nombre d'opérateurs commerciaux de drones déclarés en Australie, au Royaume-Uni, en France et aux États-Unis en février 2016. https://fr.statista.com/statistiques/ 638340/operateurs-commerciaux-enregistres-monde/. Accessed 5 July 2017

Szantol Z, Smith SE, Strona G, Koh LP, Wich SA (2017) Mapping orang-utan habitat and agricultural areas using Landsat OLI imagery augmented with unmanned aircraft system aerial photography. Int J Remote Sens 30(8/10):2231-2245 
Teal Group (2013) Estimated worldwide production value for unmanned aerial vehicles (military drones) from 2013 to 2022 (in million U.S. dollars). Available via Statista, the statistics portal. www.statista.com/statistics/428935/global-production-value-forecast-for-unmanned-aerial-systemsor-drones/. Accessed 5 July 2017

The Guardian (2015a) Major unmanned aerial vehicle (drone) importing countries between 2010 and 2014, by market share. Available via Statista, the statistics portal. www.statista.com/ statistics/429100/major-importing-countries-of-drones/. Accessed 5 July 2017

The Guardian (2015b) Major unmanned aerial vehicle (drone) exporting countries between 2010 and 2014, by market share. Available via Statista, the statistics portal. www.statista.com/ statistics/429171/major-exporting-countries-of-drones/. Accessed 5 July 2017

Todrone (2016) 1er barómetro del sector de los drones en España. www.todrone.com/wp-content/ uploads/pdf/Informe-Barometro-todrone-baja.pdf. Accessed 22 July 201721

Tractica (2016) Global consumer drones revenue from 2015 to 2021 (in million U.S. dollars). Available via Statista, the statistics portal. www.statista.com/statistics/608931/consumerdrone-revenue-worldwide/. Accessed 5 July 2017

Tractica (2017a) Projected commercial drone revenue worldwide from 2015 to 2025 (in million U. S. dollars). Available via Statista, the statistics portal. www.statista.com/statistics/607922/ commercial-drone-market-revenue-worldwide-projection/. Accessed 5 July 2017

Tractica (2017b) Projected commercial drone revenue in Europe from 2015 to 2025 (in million U. S. dollars). Available via Statista, the statistics portal. www.statista.com/statistics/607794/ commercial-drone-market-revenue-in-europe-projection/. Accessed 5 July 2017

Tractica (2017c) Drones for commercial application. Available via Statista, the statistics portal. www.statista.com/statistics/607897/commercial-drone-market-revenues-in-middle-east-andafrica-projection/; www.statista.com/statistics/607794/commercial-drone-market-revenue-ineurope-projection/; www.statista.com/statistics/607872/commercial-drone-market-revenue-inlatin-america-projection/; www.statista.com/statistics/607769/commercial-drone-market-revenuein-north-america-projection/; www.statista.com/statistics/607808/projection-of-the-commercialdrone-market-revenue-in-asia-pacific/. Accessed 17 July 2017

Venter P, Wright A, Dibb S (2015) Performing market segmentation: a performative perspective. J Mark Manag 31(1-2):62-83

Wichmann T (2017) Expanding drone operations into Europe. Available via Skyward. https:// skyward.io/expanding-commercial-drone-operations-into-europe/. Accessed 21 July 2017

Wind Y (1978) Issues and advances in segmentation research. J Mark Res 15(3):317-337

Open Access This chapter is licensed under the terms of the Creative Commons Attribution 4.0 International License (http://creativecommons.org/licenses/by/4.0/), which permits use, sharing, adaptation, distribution and reproduction in any medium or format, as long as you give appropriate credit to the original author(s) and the source, provide a link to the Creative Commons license and indicate if changes were made.

The images or other third party material in this chapter are included in the chapter's Creative Commons license, unless indicated otherwise in a credit line to the material. If material is not included in the chapter's Creative Commons license and your intended use is not permitted by statutory regulation or exceeds the permitted use, you will need to obtain permission directly from the copyright holder.

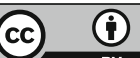




\title{
European Union Policies and Civil Drones
}

\author{
Virginia Santamarina Campos
}

\begin{abstract}
This chapter provides an analysis of the drone policies in the European Union, divided into types of actors (manufacturers, operators, and pilots), drones (more or less than $150 \mathrm{~kg}$, risk classification), licenses, and insurance (depending on the drone and the activity), at the European level. All these policies affect producers and operators. The problems related to licenses, the type of drone and activity, and the chance of obtaining insurance will have an impact on the development of the drone industry in the future. According to the European Union, there are two main current recommendations when regulating drone use: (a) distinguish not by mass but by risk (although mass is a parameter to bear in mind) and (b) do not distinguish the use/mission of the drone, since, depending on the drone, the risks can be the same for both professional and hobby/leisure use.
\end{abstract}

\section{Introduction}

Many proposals concerning how to classify drones, RPASs (remotely piloted aircraft systems), UASs (unmanned aircraft systems), or UAVs (unmanned aerial vehicles) can be found in specific literature, and a comparison of these can be consulted in, for example, Hassanalian and Abdelkefi (2017). A basic classification first of all distinguishes the mission of the drone: civilian or military. Of course, one question immediately arises in both cases: why employ a drone? The advantages for both civilian and military missions are quite obvious: the "flying robots" are unmanned. Thus, for example in military operations, the injury/loss of a pilot can be avoided. However, this is also true for civilian purposes. The inspection of a bridge can be performed by a drone (RPAS), and no engineer has to climb or abseil for monitoring purposes. Deployment and maintenance are also cheaper, which is another benefit when drones are employed. This has made basic and applied research in the last years attractive for both types of mission, civilian and military.

\footnotetext{
V. Santamarina Campos $(\bowtie)$

Universitat Politècnica de València, Valencia, Spain

e-mail: virsanca@upv.es

(C) The Author(s) 2018 
As a consequence, great technological progress has been achieved, leading to the successful introduction of drones into the mass market with low prices and their use in different sectors, such as leisure, cultural heritage, industrial inspections, agriculture, emergencies, surveillance, transport, health, and so on.

This is reflected in the fact that the drone market has increased exponentially in the last years. As shown in Fig. 1, not only manufacturers but also services compound this sector, in which manufacturers and components comprised $45 \%$ in 2016 (platforms $29 \%$ and components and systems 16\%), while related activities included the remaining $65 \%$, such as services (20\%), universities and research programmes $(10 \%)$, software $(7 \%)$, news/media/blogs $(6 \%)$, coalitions/organizations/ initiatives $(5 \%)$, conferences and events $(3 \%)$, operator marketplaces $(2 \%)$, drone insurance $(2 \%)$, and user groups/networks $(1 \%)$.

On the other hand, new applications can generate a larger market in the coming years, in which the business opportunities can generate a value of more than 127 million dollars (Table 1).

However, this situation entails a legal vacuum, whereby drones fall outside the aviation rules if their weight is less than $150 \mathrm{~kg}$ (Regulation CE no. 216/2008), and in this case each Member State of the European Agency of Safety Aviation (EASA) has to define its own parameters (EASA 2015, 2017).

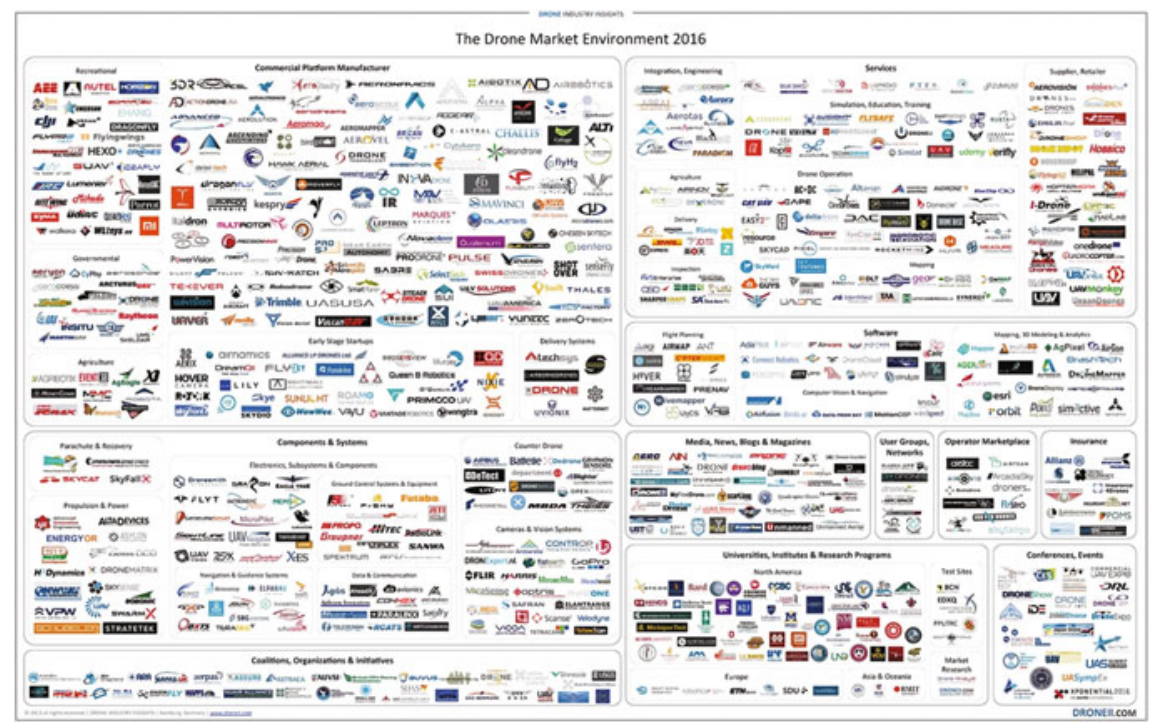

Fig. 1 The drone market environment map 2016, with permission of the company. Source Droneii (2016) 
Table 1 Value of drone powered solutions' addressable industries: global view (\$ bn)

\begin{tabular}{l|r}
\hline & 2015 \\
\hline Infrastructure & 45.2 \\
\hline Transport & 13.0 \\
\hline Insurance & 6.8 \\
\hline Media and Ent. & 8.8 \\
\hline Telecommunication & 6.3 \\
\hline Agriculture & 32.4 \\
\hline Security & 10.5 \\
\hline Mining & 4.3 \\
\hline Total & 127.3 \\
\hline
\end{tabular}

Source PwC (2016)

\section{Actors}

According to the EASA (2015, 2017), different stakeholders are affected by civil drones: national aviation authorities, the aviation industry, air navigation service providers (ANSPs), airspace users (or pilots), manufacturers, drone operators, and the general public.

In our research five main parties should be taken into account:

- Drone manufacturers: that is, the producers of the final product. They could be from the EU or from a non-EU country. Nevertheless, all of them should comply with the EU country requirements.

- Operators: people holding a license to navigate a drone as well as people who give training to other pilots. That is, their drone use has purely a professional/ commercial purpose.

- Pilots/users: they can also be operators when there is professional/commercial use of the drone, but they might also hold no license if the drone weight is below a specific value and is used just for hobby/leisure purposes.

- Members of the general public: their safety and security can be affected by a drone. The main concerns for people are related to safety, the environment, privacy, and data protection (Smith 2014).

- The economy: businesses that may include the use of UASs in their business model to lower costs and/or add new innovative services.

In the case of civil drones weighing less than $150 \mathrm{~kg}$, it is apparent that different European countries regulate the activity of these actors differently. For example, in 2016 the use of camera drones was made illegal in Sweden by its Supreme Administrative Court unless the users have been granted a special surveillance permit (BBC 2016), even though in 2014 more than 1000 permits were issued for the use of camera drones for commercial purposes in this country. 


\section{European Policies: A Brief Review}

The EASA (2015: 4) provided a regulatory definition of a drone, which could be very useful in the case of courts' discrepancies:

Drone shall mean an aircraft without a human pilot on board, whose flight is controlled either autonomously or under the remote control of a pilot on the ground or in another vehicle.

Moreover, a consultation for this Advance Notice of Proposed Amendment (A-NPA) (EASA 2015) was open until 25 September 2015. This proposal basically distinguished three categories of drones depending on the risks associated with people and property: open (low risk), specific (medium risk), and certified (high risk) (Fig. 2).

- 'Open' category (low risk): this could include indoor drones

- 'Specific operation' category (medium risk): a manual of operations with a list of the risk mitigation measures will be required

- 'Certified' category (higher risk): a licence and approval of maintenance, operations, training, and so on will be required.

Following that proposal, a new one was presented by the EASA in (2017) to create a regulatory framework for the operation of drones in the case of the open and specific categories. This draft was available for enquiry until 15 September 2017. All this information will be used by the EASA to elaborate a comment review document (CRD).

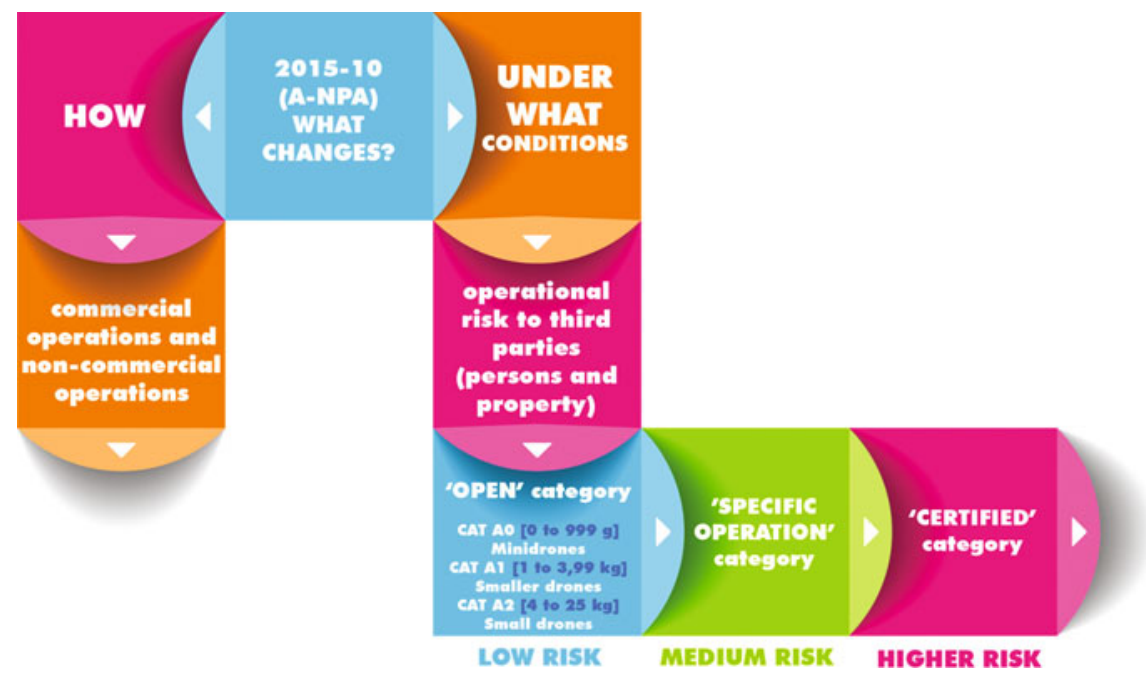

Fig. 2 Changes proposed by the EASA. Source own elaboration adapted from the EASA 
The European Council and the Parliament are continuing to work together to provide a common regulatory framework to support the European competitiveness and leadership in the drone sector to deliver new employment and business opportunities and, at the same time, to respect safety, privacy, and the environment, as stated in the Warsaw Declaration (EASA 2016).

This new regulatory framework is supposed to be presented to the European Commission by the end of 2017, so at present licences and assurances and types of activities and drones are still regulated differently by the European countries, as we can see in the chapters "Spain-UK-Belgium Comparative Legal Framework" and "Legal and Ethical Recommendations".

However, some countries have started to change their own regulations. For example, in the UK, even with the "Brexit" process pending and without knowing whether that future framework will be applied in this country, in 2017 the Government announced a plan to require the owners of drones weighing more than $250 \mathrm{~g}$ to register their devices (TechCrunch 2017). Moreover, a new drone safety awareness test will have to prove that the drone operators understand the relevant safety, security, and privacy regulations.

\section{Insurance Regulations and Drones in the European Union}

The European Insurance Regulation on the insurance requirements for air carriers and aircraft operators (European Commission 2004) requires them to be insured with some exceptions: among them, these include model aircrafts with a maximum take-off mass (MTOM) of less than $20 \mathrm{~kg}$ when used for non-commercial purposes. However, even though there is no definition of what a model aircraft is for the purposes of the European Insurance Regulation, it is assumed that it encompasses drones. Therefore, an operator is exempt from the insurance requirement if he/she uses a drone weighing less than $20 \mathrm{~kg}$ for non-commercial purposes (Farrar's Building 2016).

Moreover, article 3 of this Regulation provides the following definition of an aircraft operator:

... means the person or entity, not being an air carrier, who has continual effective disposal of the use or operation of the aircraft; the natural or legal person in whose name the aircraft is registered shall be presumed to be the operator, unless that person can prove that another person is the operator.

Furthermore, a commercial operation is defined as "an operation for remuneration and/or hire". Therefore, any purpose that could generate income must be a commercial purpose and require the drone operator to hold insurance; in this sense most commercial uses will be obvious if the drone is being used by a company or organization (Farrar's Building 2016). 


\section{Conclusions}

The drone market has increased exponentially in the last years, and many involved parties depend on drone activities: national aviation authorities, the aviation industry, the general public, manufacturers and operators of drones, air navigation service providers (ANSPs), and airspace users (or pilots). However, at present, without a common regulatory framework, different European countries regulate the activity of these actors in different ways. Those uncertainties hamper the economic development of this big European market.

While in the case of professional and commercial activities the rules seem to be easier to approach (as, for example, in the case of insurance for drones), the regulation of recreational activities might be quite difficult. For this reason the European Agency of Safety Aviation (EASA) is continuing to work to provide a common regulatory framework to support the European competitiveness and leadership in the drone sector, to deliver new employment and business opportunities, and, at the same time, to give other European citizens who could be affected by drones' activity more safety and security.

\section{References}

BBC (2016) Sweden bans cameras on drones. http://www.bbc.com/news/technology-37761872. Accessed 18 August 2017

Droneii (2016) The drone market environment map 2016. https://www.droneii.com/drone-marketenvironment-map-2016. Accessed 7 August 2017

EASA (2015) Advance notice of proposed amendment 2015-10, A-NPA. https://www.easa. europa.eu/system/files/dfu/A-NPA\%202015-10.pdf. Accessed 6 July 2017

EASA (2016) Warsaw declaration: drones as a leverage for jobs and new business opportunities. https://ec.europa.eu/transport/sites/transport/files/drones-warsaw-declaration.pdf. Accessed 18 August 2017

EASA (2017) Notice of proposed amendment 2017-05, B-NPA. Introduction of a regulatory framework for the operation of drones, unmanned aircraft system operations in the open and specific category. https://www.easa.europa.eu/system/files/dfu/NPA\%202017-05\%20\%28B\% 29.pdf. Accessed 18 August 2017

European Commission (2004) Regulation (EC) no. 785/2004 of the European Parliament and of the Council of 21 April 2004 on insurance requirements for air carriers and aircraft operators. Available via EURLEX. http://eur-lex.europa.eu/legal-content/EN/TXT/HTML/?uri=CELEX: 32004R0785\&from=EN. Accessed 21 August 2017

Farrar's Building (2016) Drones and insurance. http://www.farrarsbuilding.co.uk/insurance-lawupdate-december-2016/\#_ftn2. Accessed 19 August 2017

Hassanalian M, Abdelkefi A (2017) Classifications, applications, and design challenges of drones: a review. Prog in Aerosp Sci 91(May):99-131

PwC (2016) Clarity from above. PwC global report on the commercial applications of drone technology. http://pwc.blogs.com/files/clarity-from-above-pwc.pdf. Accessed 7 August 2017

Smith ML (2014) Regulating law enforcement's use of drones: the need for state legislation. Harv J Legis 52:423-455. https://doi.org/10.2139/ssrn.2492374

TechCrunch (2017) Drone registration coming to the UK. https://techcrunch.com/2017/07/22/ drone-registration-coming-to-the-uk/. Accessed 18 August 2017 
Open Access This chapter is licensed under the terms of the Creative Commons Attribution 4.0 International License (http://creativecommons.org/licenses/by/4.0/), which permits use, sharing, adaptation, distribution and reproduction in any medium or format, as long as you give appropriate credit to the original author(s) and the source, provide a link to the Creative Commons license and indicate if changes were made.

The images or other third party material in this chapter are included in the chapter's Creative Commons license, unless indicated otherwise in a credit line to the material. If material is not included in the chapter's Creative Commons license and your intended use is not permitted by statutory regulation or exceeds the permitted use, you will need to obtain permission directly from the copyright holder.

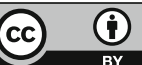




\title{
Spain-UK-Belgium Comparative Legal Framework: Civil Drones for Professional and Commercial Purposes
}

\author{
Miguel Rosa, Gavin O'Brien and Vadim Vermeiren
}

\begin{abstract}
The aim of this study is to compare the regulations of the three European countries applied to drones or RPASs (remotely piloted aircraft systems) to find similarities and differences, particularly in the use of civil drones for professional and commercial purposes. This analysis gives a clear understanding of the requirements that each country establishes to operate with drones in its territory. As a general rule, countries regulate the activity of drones in their territory by residents in the country, although they leave the door open to operators from other countries to operate legally. In general, the focus of international and national regulations is given to safety. Nevertheless, small drones avoid many of these requirements, as they weigh less than $150 \mathrm{~kg}$ and pose fewer risks to people. However, bearing in mind that this kind of work could be related to creative industries, on a professional level, insurance should cover any property damage.
\end{abstract}

\section{Introduction}

Since approximately 2011 there has been an increasing tendency to legislate the use of drones in the civil sphere, countries being incorporated with more or less celerity into a regulatory process that is lengthened by the aeronautical approach adopted. Drones are rated as aircraft and treated as such in the use of airspace and in their relationship with other users, both active (other aircraft) and passive (people who

\footnotetext{
M. Rosa (ه)

Aerotools, Alcobendas (Madrid), Spain

e-mail: miguel.rosa@aerotools-uav.es

G. O'Brien

Clearhead, Luton, United Kingdom

V. Vermeiren

Pozyx, Ghent, Belgium

(C) The Author(s) 2018 
are outside the scope of use but who may be affected), with a requirement for safety conditions in the operation that are comparable as far as possible to those of manned aviation.

As Bernauw (2016) highlights, Art. 8 of the Chicago Convention (ICAO 2006) subjects the operation of drones to national authorization. The consequence at present is a regulatory environment that differs between the respective countries, from permissive to restrictive, while the professional and commercial use of drones has an impact on safety that must be addressed.

In countries that already have legislation, there is evidence of some homogeneity in some aspects of regulation, as is the case with the weight limits (MTOW, maximum take-off weight) of regulated aircraft, the operation limits (height, distance to the pilot, etc.), or the registration requirements for the operator, although there is no harmonized regulation in common spaces such as the European Union (EU). In this regard the strategy has been defined to achieve common European legislation (towards 2018), and working groups have been established to develop it under the ward of the Council, the European Commission, and the European Parliament, with the EASA (European Aviation Safety Agency) working on drafting legislation.

Bearing in mind that, although there will be a common European regulation, there will always be differences from the regulation of other countries outside the EU. The approach of this study is to attain adequate practical knowledge of the regulation of each country to provide academia with a comparative legal framework as well as to give the user a tool to obtain this information. The parameters analysed are:

- Updated legislation applied in each country;

- Limitations for operating drones;

- Compulsory requirements for operators, drones, and pilots to operate drones.

As a sector that is in the process of settlement and based on technologies that evolve very quickly, it is important to keep in mind at all times that there will be a frequent dynamic of changes and updates of legislation until standardized forms of technology utilization are adopted. For this reason references are included to regulatory agencies and links to the information sources, with the date of the last version of legislation in force.

A table has been drawn up (Table 1) to provide a reference document containing adequate knowledge of the specific legislation. The nomenclature and explanation of the sections are detailed. The table's format tries to parameterize or group the most relevant aspects of each of the regulations under study in sections that are common or at least similar. Although at first glance this is a complicated task due to the different ways of approaching drones' operation, control, and regulation in each country, some common areas have been defined to provide an appropriate guide to be introduced in each piece of legislation. 
Table 1 Proposal for a reference document to compare drone regulations related to operators and pilots

\begin{tabular}{|c|c|c|}
\hline & Country & Current regulation \\
\hline & Parameters & Comments \\
\hline \multicolumn{3}{|l|}{ Administration and regulation } \\
\hline Regulatory body & Regulatory body name & $\begin{array}{l}\text { Link provided in the } \\
\text { reference list }\end{array}$ \\
\hline Date of last normative update & $\begin{array}{l}\text { Date of last normative } \\
\text { update }\end{array}$ & Law that publishes it \\
\hline Normative identification & Normative name & $\begin{array}{l}\text { Link provided in the } \\
\text { reference list }\end{array}$ \\
\hline \multicolumn{3}{|l|}{ Limits to operation } \\
\hline $\begin{array}{l}\text { MTOW (maximum take-off } \\
\text { weight) }\end{array}$ & Value & $\begin{array}{l}\text { Maximum take-off mass } \\
\text { limit value }\end{array}$ \\
\hline Divisions according to MTOW & Value & Value that limits divisions \\
\hline Maximum flight height & Value & Value \\
\hline VLOS (visual line of sight) & Value & Explanation of conditions \\
\hline VLOS_distance to pilot & Value & Explanation of conditions \\
\hline $\begin{array}{l}\text { EVLOS (extended visual line of } \\
\text { sight) }\end{array}$ & Value & Explanation of conditions \\
\hline $\begin{array}{l}\text { BVLOS (beyond visual line of } \\
\text { sight) }\end{array}$ & Value & Explanation of conditions \\
\hline $\begin{array}{l}\text { Number of RPASs piloted by the } \\
\text { same pilot }\end{array}$ & Value & Value \\
\hline Areas of operation & Description & Explanation if needed \\
\hline Periods of operation & Value & Explanation if needed \\
\hline $\begin{array}{l}\text { Dangerous goods and substances } \\
\text { shipped }\end{array}$ & Value & Explanation if needed \\
\hline Flight zones & Aeronautical zone & Requirements \\
\hline Distance from airports & Value & Explanation if needed \\
\hline \multicolumn{3}{|c|}{ Requirements for the operator (Documentation) } \\
\hline Registration request & Value (yes/no) & Explanation if needed \\
\hline Test flight request & Value (yes/no) & Explanation if needed \\
\hline RPAS characterization sheet & Value (yes/no) & Explanation if needed \\
\hline Safety study & Value (yes/no) & Explanation if needed \\
\hline Operation manual & Value (yes/no) & Explanation if needed \\
\hline Maintenance manual & Value (yes/no) & Explanation if needed \\
\hline Additional measures & Value (yes/no) & Explanation if needed \\
\hline Incident notifications & Value (yes/no) & Explanation if needed \\
\hline Civil liability insurance & Value (yes/no) & Explanation if needed \\
\hline $\begin{array}{l}\text { Requirements according to } \\
\text { operators' origin }\end{array}$ & Value & Explanation if needed \\
\hline $\begin{array}{l}\text { Special permit to operate for } \\
\text { foreigners }\end{array}$ & Value & Explanation if needed \\
\hline
\end{tabular}


Table 1 (continued)

\begin{tabular}{|c|c|c|}
\hline & Country & Current regulation \\
\hline & Parameters & Comments \\
\hline \multicolumn{3}{|l|}{ Requirements for pilots } \\
\hline Type of qualification (license) & Type & Explanation if needed \\
\hline Basic & Value & Explanation if needed \\
\hline Advanced & Value & Explanation if needed \\
\hline Practical qualification & Value & Explanation if needed \\
\hline Requirements & Value & Explanation if needed \\
\hline Flight/training hours & Value & Explanation if needed \\
\hline Divisions according to MTOW & Value & Explanation if needed \\
\hline Medical certificate & Value (yes/no) & Explanation if needed \\
\hline Language & Value & Explanation if needed \\
\hline Radiophonist license & Value & Explanation if needed \\
\hline \multicolumn{3}{|l|}{ Requirements for RPASs } \\
\hline Identification/registration & Element & Explanation if needed \\
\hline Airworthiness certification & Value & Explanation if needed \\
\hline Command and control link & Value & Explanation if needed \\
\hline Maintenance & Type & Explanation if needed \\
\hline Test flights & Type & Explanation if needed \\
\hline \multicolumn{3}{|l|}{ Requirements for operation } \\
\hline Previous communication & Value & Explanation if needed \\
\hline Permission & Value & Explanation if needed \\
\hline Non-segregated airspace & Value & Explanation if needed \\
\hline Exceptions & Value & Explanation if needed \\
\hline Use of RPASs in emergency cases & Value & Explanation if needed \\
\hline $\begin{array}{l}\text { RPAS protection and recovery } \\
\text { areas }\end{array}$ & Value & Explanation if needed \\
\hline VLOS & Value & Explanation if needed \\
\hline EVLOS & Value & Explanation if needed \\
\hline BVLOS & Value & Explanation if needed \\
\hline
\end{tabular}

Source Own elaboration

\section{Regulatory Framework General Evolution}

For some years aeronautical authorities have been concerned about the generalization of drones' use, and since 2011 an important effort has been made to integrate these aircraft into the air space with the maximum safety conditions for all users. The problems are the coordination of the different sensitivities and the establishment of a technical scheme suitable for all countries. From the ICAO (International Civil Aviation Organization), coordination is attempted somehow mildly, and the main efforts are exerted through the JARUS organization (Joint 
Authorities for Regulation of Unmanned Systems) or through the States within the European Union. Consequently, as it can be seen, different actors influence this regulatory framework, which can sometimes be confusing.

\subsection{European Parliament Ruling on Drones}

Being aircraft, drones have to comply with aviation safety rules. International civil aviation rules at the United Nations level have prohibited unmanned aircraft from flying over another state's territory without its permission since 1944. In the EU the current regulatory system for drones is based on fragmented rules, with many Member States having already regulated or planning to regulate some aspects of civil drones with an operating mass of $150 \mathrm{~kg}$ or less. The responsibility for civil drones of over $150 \mathrm{~kg}$ is left to the European Aviation Safety Agency (EASA). However, the extent, content, and level of detail of national regulations differ, and conditions for mutual recognition of operational authorization between EU Member States have not been reached.

In 2012, having completed a set of consultations, the Commission published a staff working document on the civil use of RPASs and established a European RPAS steering group to plan and coordinate EU work on civil RPASs. In 2013 the steering group presented its recommendations in a roadmap that covers all types of RPASs except model aircraft and toys. The roadmap identifies potential improvements to the existing regulatory framework and outlines the research and technologies necessary for the safe integration of RPASs into the EU aviation system.

Subsequently, in 2014 the Commission adopted a Communication outlining a strategy for opening the aviation market to the civil use of RPASs in a safe and sustainable manner. It focuses on how to enable the development of RPASs while at the same time addressing their societal impact. The Commission noted its intention to take a step-by-step approach by first regulating drone operations with mature technologies. More complex operations would be permitted progressively. In the longer term, the objective is to integrate RPASs into non-segregated airspace, which is open to all civil air transport.

\subsection{European Aviation Safety Agency (EASA)}

The European Aviation Safety Agency (EASA) has been tasked by the European Commission to develop a regulatory framework for drone operations and proposals for the regulation of "low-risk" drone operations. To achieve this, the EASA is working closely with the Joint Authorities for Regulation of Unmanned Systems (JARUS).

Regulation (EC) No. 216/2008 mandates the Agency to regulate unmanned aircraft systems (UASs) and in particular remotely piloted aircraft systems (RPASs) 
when used for civil applications and with an operating mass of $150 \mathrm{~kg}$ or more. Experimental or amateur-built RPASs, military and non-military governmental RPAS flights, and civil RPASs below $150 \mathrm{~kg}$, as well as model aircraft, are regulated by the individual Member States of the European Union.

The EASA has been tasked by the European Commission-following the Riga Conference (held in 2015) and its associated Declaration - to develop a regulatory framework for drone operations as well as concrete proposals for the regulation of low-risk drone operations.

The "Advance notice of proposed amendment 2015-10" (A-NPA) (EASA 2015a) reflects the principles laid down in the Riga Declaration. It follows a riskand performance-based approach; it is progressive- and operation-centric. It introduces three categories of operations as already proposed in the published EASA "Concept of operations for drones":

- An "open" category (low risk): safety is ensured through operational limitations, compliance with industry standards, requirements for certain functionalities, and a minimum set of operational rules. Enforcement shall be ensured by the police. In this group we could also include indoor drones.

- A "specific operation" category (medium risk): authorization by National Aviation Authorities (NAAs), possibly assisted by a qualified entity (QE) following a risk assessment performed by the operator. A manual of operations shall list the risk mitigation measures.

- A "certified" category (higher risk): requirements comparable to manned aviation requirements. Oversight by NAAs (issue of licences and approval of maintenance, operations, training, air traffic management (ATM)/air navigation services (ANS), and aerodrome organizations) and by the EASA (design and approval of foreign organizations).

This regulatory framework will encompass European rules for all drones in all weight classes. The amendments to Regulation (EC) No. 216/2008 that are underway will reflect the above.

Besides, in December 2015 the Agency published a Technical Opinion (EASA 2015b) that contains, in its section 4, an update of the roadmap published by the European RPAS Steering Group (ESRG) in 2013 (ESRG 2013). This Technical Opinion is the result of the consultation performed with A-NPA 2015-10. It has been developed in parallel to the draft modifications to Regulation (EC) No. 216/ 2008 (hereinafter referred to as the "Basic Regulation") included in the "Aviation Strategy to Enhance the Competitiveness of the EU Aviation Sector" (hereinafter referred to as the "Aviation Strategy"), published on 7 December 2015.

The Agency also supports the work of the ICAO (International Civil Aviation Organization) UAS Study Group. The ICAO published Circular 328 (2011) on UASs and amended Annexes 2, 7, and 13 to the Chicago Convention to accommodate RPASs intended to be used by international civil aviation. 
Moreover, the EASA is member of the Joint Authorities for Rulemaking on Unmanned Systems (JARUS), which is currently developing recommended requirements for:

- Licensing of remote pilots;

- RPASs in visual (VLOS) and beyond line-of-sight (BVLOS) operations;

- Civil RPAS operators and approved training organizations for remote pilots (JARUS-ORG);

- Certification specifications for light unmanned rotorcraft (CS-LURS) and aeroplanes (CS-LURS) below $600 \mathrm{~kg}$;

- Performance requirements for "detect and avoid" to maintain the risk of mid-aid collision below a tolerable level of safety (TLS) and taking into account all the actors in the total aviation system;

- Performance requirements for command and control data link, whether in direct radio (RLOS) or beyond line-of-sight (BRLOS) and in the latter case supported by a communication service provider (COM SP);

- Safety objectives for the airworthiness of RPASs ("1309") to minimize the risk of injuries to people on the ground; and

- Processes for airworthiness.

The EASA has already published:

- Guidance material to support approved design organizations (DOA or AP-DOA) in selecting the appropriate certification specifications (among the ones applicable to manned aviation) from which to build the certification basis for RPAS design (see E.Y013-01);

- NPA 2012-10 to transpose amendment 43 to ICAO Annex 2 into the Standard European Rules of the Air (SERA).

\subsection{Joint Authorities for Regulation of Unmanned Systems (JARUS)}

JARUS is a group of experts gathering regulatory expertise from all around the world. At present 48 countries, as well as the European Aviation Safety Agency (EASA) and EUROCONTROL, are contributing to the development of JARUS's work products. Participation in JARUS is open to all regulatory authorities with expertise in unmanned or remotely piloted aircraft systems.

The purpose of JARUS is "to recommend a single set of technical, safety and operational requirements for all aspects linked to the safe operation of the Remotely Piloted Aircraft Systems (RPAS). This requires review and consideration of existing regulations and other material applicable to manned aircraft, the analysis of the specific tasks linked to RPAS and the drafting of material to cover the unique features of RPAS" (JARUS 2015a). 
The JARUS guidance material aims to facilitate each authority to write its own requirements and to avoid duplicate efforts. The work is performed by the JARUS working groups; seven WGs are active at this moment (JARUS 2015b): WG1 Flight Crew Licensing, WG2 Operations, WG3 Airworthiness, WG4 Detect \& Avoid, WG5 Command, Control \& Communications, WG6 Safety \& Risk Management, WG7 Concept of Operations.

In the last three years, it has published and made available to the RPAS community some deliverables to clarify concepts or recommend some uses. It is working to provide further inputs into the development of RPAS and UAS regulatory guidance and recommendations in domains in which other organizations (e.g. the ICAO) have not been active.

JARUS is creating a high-level framework that will be at the heart of the development effort. This effort is based on a number of high-level "concepts of operations" (CONOPS) addressing the key elements of the operation of UASs. These CONOPS set high-level assumptions that should guide the work activities in the coming years. They are aimed at providing a stable yet flexible environment, in which JARUS's work products can be developed and amended as necessary. This will allow innovation to take place with a level of certainty. The members of JARUS have agreed to develop these CONOPS for the following subjects:

- Regulatory oversight with three categories - A, B, and C or open, specific, and certified;

- UAS operational categorization;

- Specific operational risk assessment specifications (SORA);

- ATM concepts for different operations;

- The detect and avoid concept for visual line of sight, extended, and beyond visual line of sight;

- Command and control, from the simplest to the most complex systems.

After JARUS has reached consensus on these concepts, other deliverables - such as operational, technical, safety, and operational requirements and certification specifications - will be derived to support them.

\subsection{International Civil Aviation Organization (ICAO)}

In the previous section on the AESA, we introduced this United Nations specialized agency. Established by States in 1944, it manages the administration and governance of the Convention on International Civil Aviation (Chicago Convention). The ICAO works with the Convention's 191 Member States and industry groups to reach consensus on international civil aviation standards and recommended practices (SARPs) and policies in support of a safe, efficient, secure, economically sustainable, and environmentally responsible civil aviation sector. These SARPs 
and policies are used by ICAO Member States to ensure that their local civil aviation operations and regulations conform to global norms.

The ICAO has developed the UAS Toolkit (ICAO 2017) as a guide to assist States that are working on the development of UAS operational guidance, regulation, and enabling operation in a safe manner. This Toolkit provides interesting guidance to take into account, but users should always be aware that it could be updated.

There seems to be a general consensus that unmanned aircraft must be allowed to operate without segregation from other air space users (Bernauw 2016).

\section{Legal Framework of Spain}

According to Pauner-Chulvi (2016), Spain was one of the first European countries to pass a technical regulation on drones.

At the national level, the body responsible for regulating the activity of drones is the State Agency for Air Safety (AESA), under the General Secretariat of Transport (Ministry of Development). It is the aeronautical authority and is responsible for the supervision, inspection, and management of air transport, air navigation, and airport security (AESA 2017a). In addition, it assesses the risks in air transport safety through threat detection, risk analysis and evaluation, and a continuous process of control and mitigation of risks. It also has sanctioning power over violations of civil aviation regulations.

Within its activity it is responsible for developing the regulation of operations with drones up to $150 \mathrm{~kg}$ and for monitoring their compliance and operation. The drone section has been framed within the Aircraft Safety Directorate, with the description of remote control piloted aircraft units (RPASs).

As the first action, Royal Decree-Law 8/2014 was passed on 4 July, giving "approval of urgent measures for growth, competitiveness and efficiency", in which section 6 included the temporary regime for operations with remotely piloted aircraft, drones, weighing less than $150 \mathrm{~kg}$ at take-off.

Subsequently, this legislation was processed as a law, Law 18/2014, on 15 October 2014, giving "approval of urgent measures for growth, competitiveness and efficiency" (AESA 2014), which is currently in force. This regulation responded to the need to establish a legal framework that would allow the safe development of a technologically advanced and emerging sector, and from the beginning it was promised that it would be developed in the short term, the Administration being aware that it was a temporary solution that needed to be improved.

This temporary regulation contemplates the different scenarios in which the different aerial works can be realized, depending on the aircraft's weight. Besides, 
the conditions now approved are supplemented by the general scheme of Law 48/1960, 21 July, on air navigation and establish the operating conditions of this type of aircraft in addition to other obligations.

Legislation on drones in Spain was published in a somewhat accelerated way in July 2014, to alleviate the sense of freedom, reinforced by the lack of information, that had spread among users over the misconception that "if it is not forbidden, it is permitted". With regard to aircraft, such as aircraft flying within certain defined parameters, there had always been legislation, and the use of model aeroplanes for many years, being restricted to a specific environment (that of fans and aeromodelling clubs), had not posed major problems.

However, the appearance of drones and the extension of their use outside the domain of model aircraft increased the number of users and potentially dangerous situations at the same time as a professional activity "sub-sector" was being formed, gaining size on a base lacking legal solidity.

By the end of 2013 and early 2014, a number of incidents involving drones had occurred, which motivated the accelerated position taken by the Ministries of Development, Defence, and Industry and the elaboration of regulations that were presented as "provisional" pending more elaborate and refined legislation.

Royal Decree 8/2014 covered the regulation of RPASs, conforming to a scenario of use that evidenced certain deficiencies but giving the possibility to undertake work and activities using drones in a legal way. Subsequently Law 18/2014 was approved.

In the years afterwards, work was carried out on new legislation to improve the aforementioned and currently in force legislation with a draft that has already circulated in its final versions and that seems only to be waiting for its approval by the Government.

Given the imminence of this new legislation, it has been considered appropriate to include and consider it at the same level as Law 18/2014, which is in force, to achieve adequate knowledge about a reality that seems close, although it must be borne in mind that changes may still be made to the wording of some points of this new regulation. The version has been developed by the Ministry of Public Works and Transport and the Ministry of Defence (2016).

To gain an adequate understanding of the regulation of drones and how it applies, it is necessary to examine the "guidance material" published by the State Agency for Air Safety (AESA 2017b), which articulates the implementation of the law.

\subsection{Current Regulation}

At the moment the regulation in force is defined by the following parameters (Table 2): 
Table 2 Administration and regulation in Spain

\begin{tabular}{l|l|l}
\hline & Spain & Actual regulation \\
\cline { 2 - 3 } & Parameters & Comments \\
\hline $\begin{array}{l}\text { Administration } \\
\text { and regulation }\end{array}$ \\
$\begin{array}{l}\text { Regulatory } \\
\text { body }\end{array}$ & AESA & $\begin{array}{l}\text { AESA: drones less than } 150 \mathrm{~kg} \\
\text { EASA: drones more than } 150 \mathrm{~kg}\end{array}$ \\
\hline $\begin{array}{l}\text { Last updated } \\
\text { normative }\end{array}$ & 15 October 2014 & $\begin{array}{l}\text { BOE (State Official Bulletin) } 17 \text { October } \\
2014\end{array}$ \\
\hline $\begin{array}{l}\text { Normative } \\
\text { identification }\end{array}$ & $\begin{array}{l}\text { Law 18/2014 Section 6th } \\
\text { Civilian aeroplanes piloted by } \\
\text { remote control }\end{array}$ & $\begin{array}{l}\text { Article } 50 \text { distinguishes drones less than 2 } \\
\mathrm{kg}, \text { drones less than } 25 \mathrm{~kg}, \text { and drones less } \\
\text { than } 150 \mathrm{~kg}\end{array}$ \\
\hline
\end{tabular}

Source Own elaboration

\subsection{New Regulation and Comparison}

There is the intention on the part of the Spanish Administration to update the legislation on drones in the short term, and it has elaborated a draft of regulation that is waiting for the last political formalities for its approval and publication.

A comparative analysis of the two regulations is displayed in Table 3. As we can observe, some parameters have no changes, while others are more detailed or adjusted.

\section{Legal Framework of the UK}

In the UK the administration authority in charge of civil drones is the Civil Aviation Authority (CAA). In relation to drones (CAA 2017a), the regulation separates drones as follows: up to $7 \mathrm{~kg}$ or up to $20 \mathrm{~kg}$ (small) and up to $150 \mathrm{~kg}$ (light). Art. 94 of the Air Navigation Order (CAA 2017b) and the regulations made under the order exclude small drones from some obligations.

However, this depends on the use of the drone. It is not compulsory to register a personal drone or obtain a permit for a recreational drone in the UK, but, if the drone is used for professional work, then a Permission for Aerial Work is needed, which has to be renewed annually (CAA 2017a).

The basic parameters are the following:

- Line of sight (LOS) at a maximum height of $400 \mathrm{ft}$ (122 m);

- $500 \mathrm{~m}$ of distance horizontally;

- In any case fly away from aircraft, helicopters, airports, and airfields;

- If fitted with a camera, a drone must be flown at last $50 \mathrm{~m}$ away from a person, vehicle, building, or structure not owned or controlled by the pilot;

- Camera-equipped drones must not be flown within $150 \mathrm{~m}$ of a congested area or large group of people, such as a sporting event or concert. 


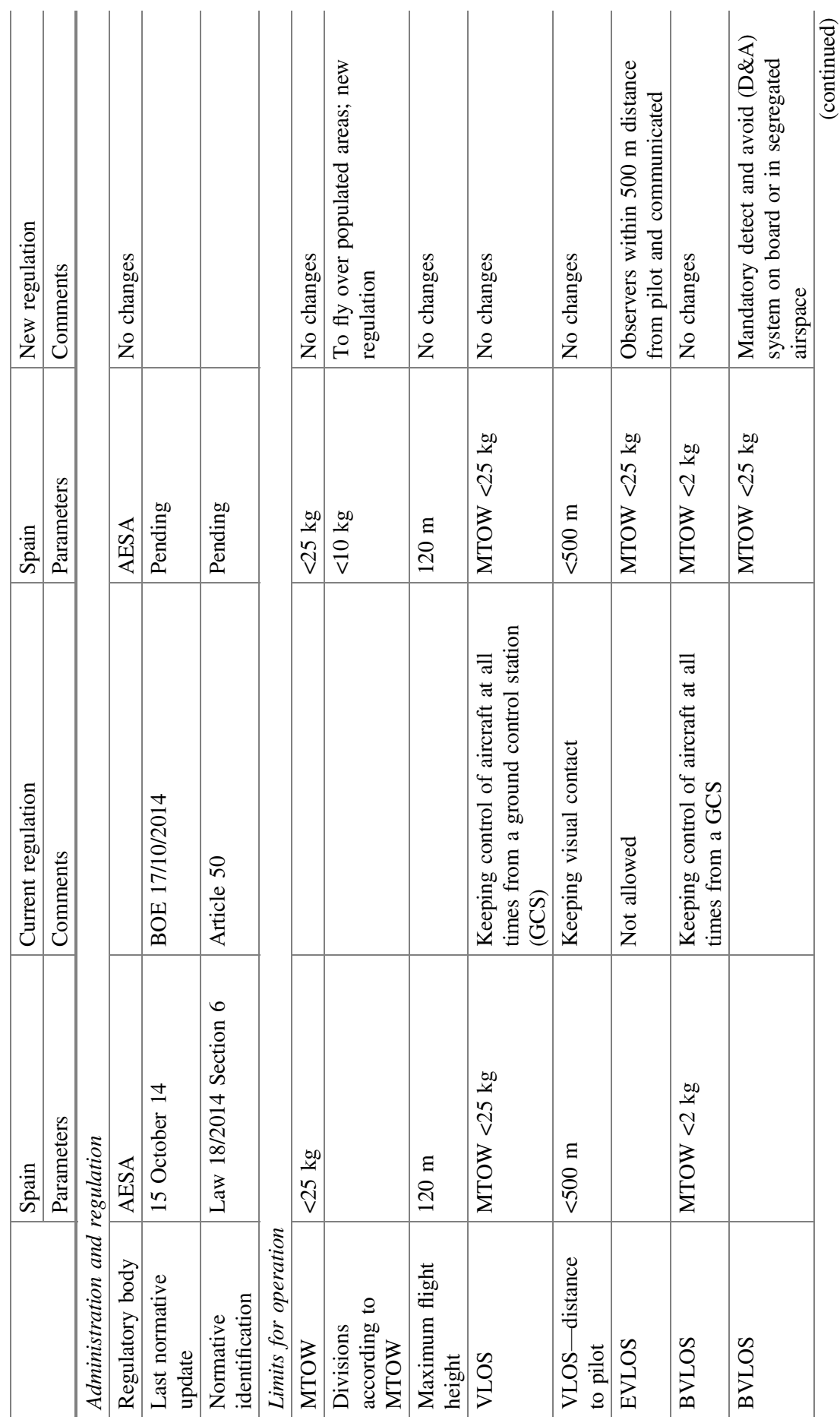




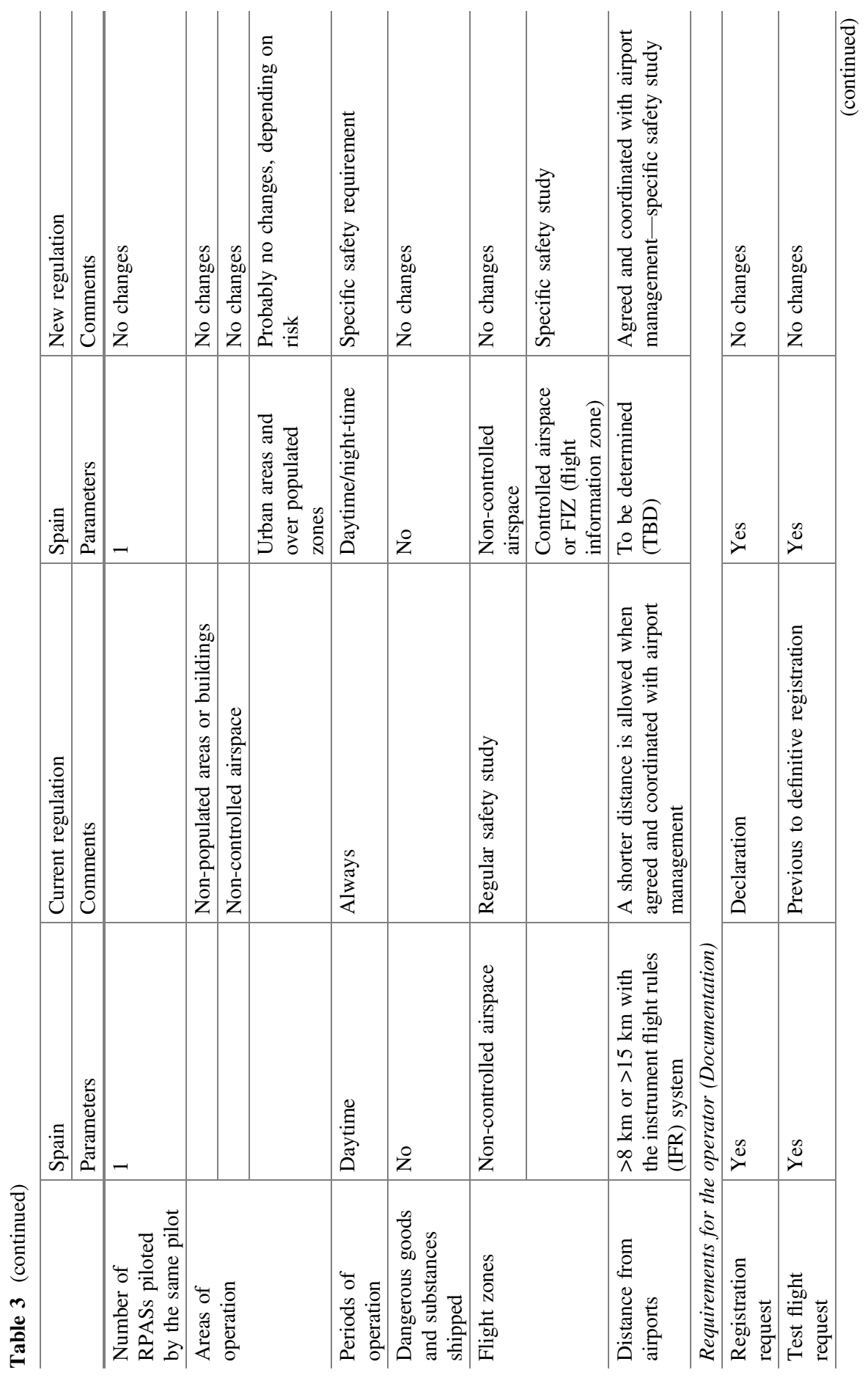




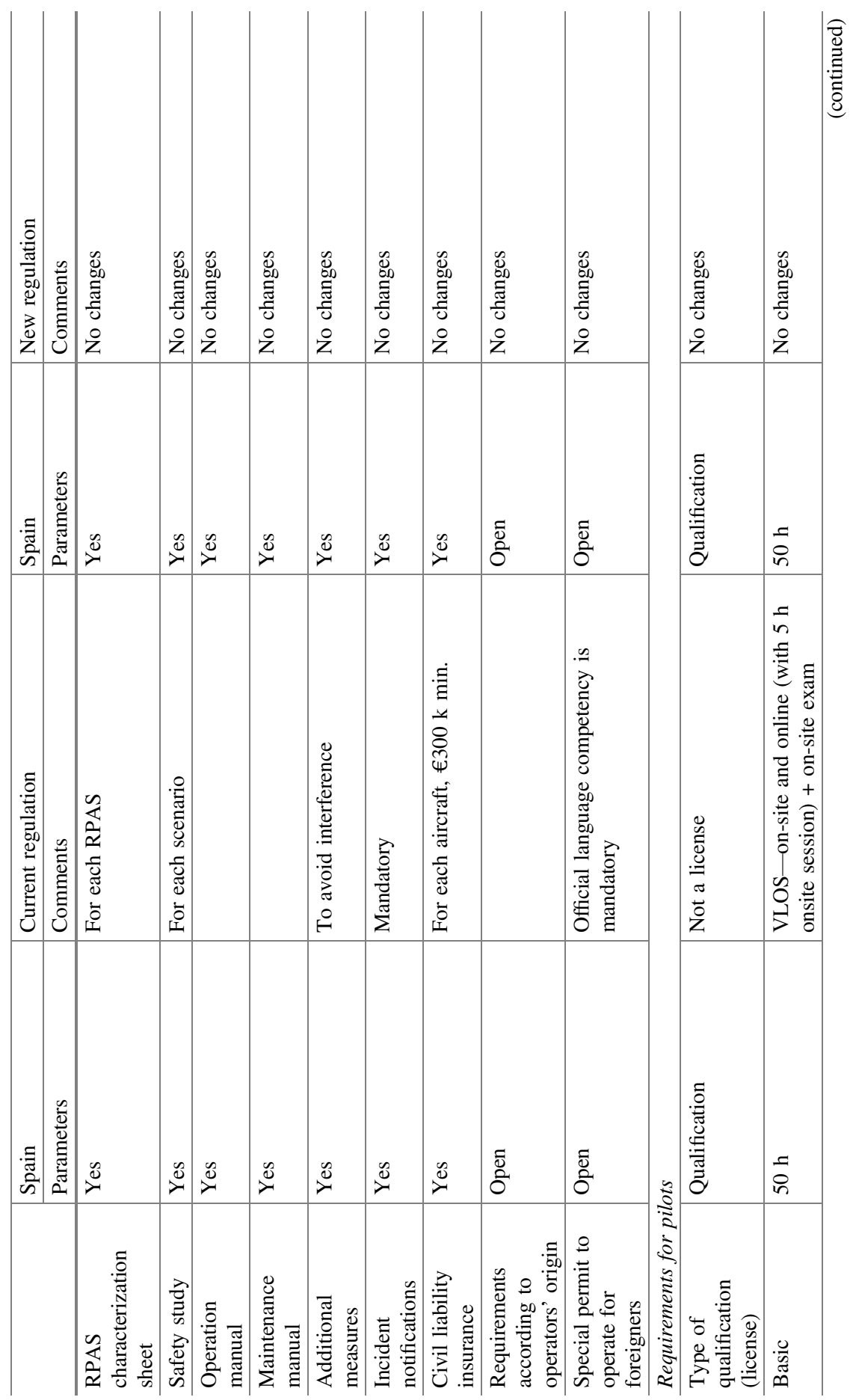




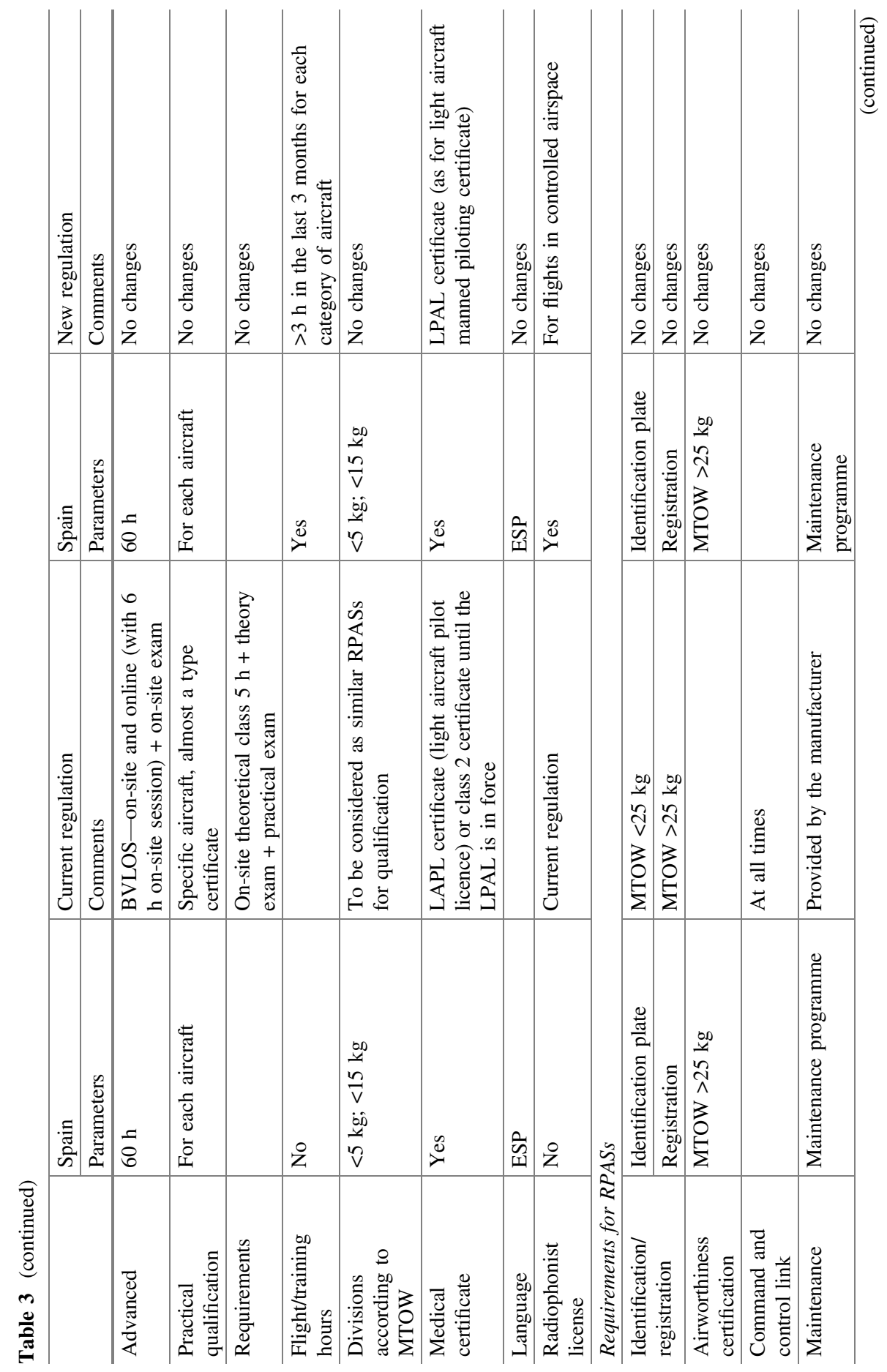




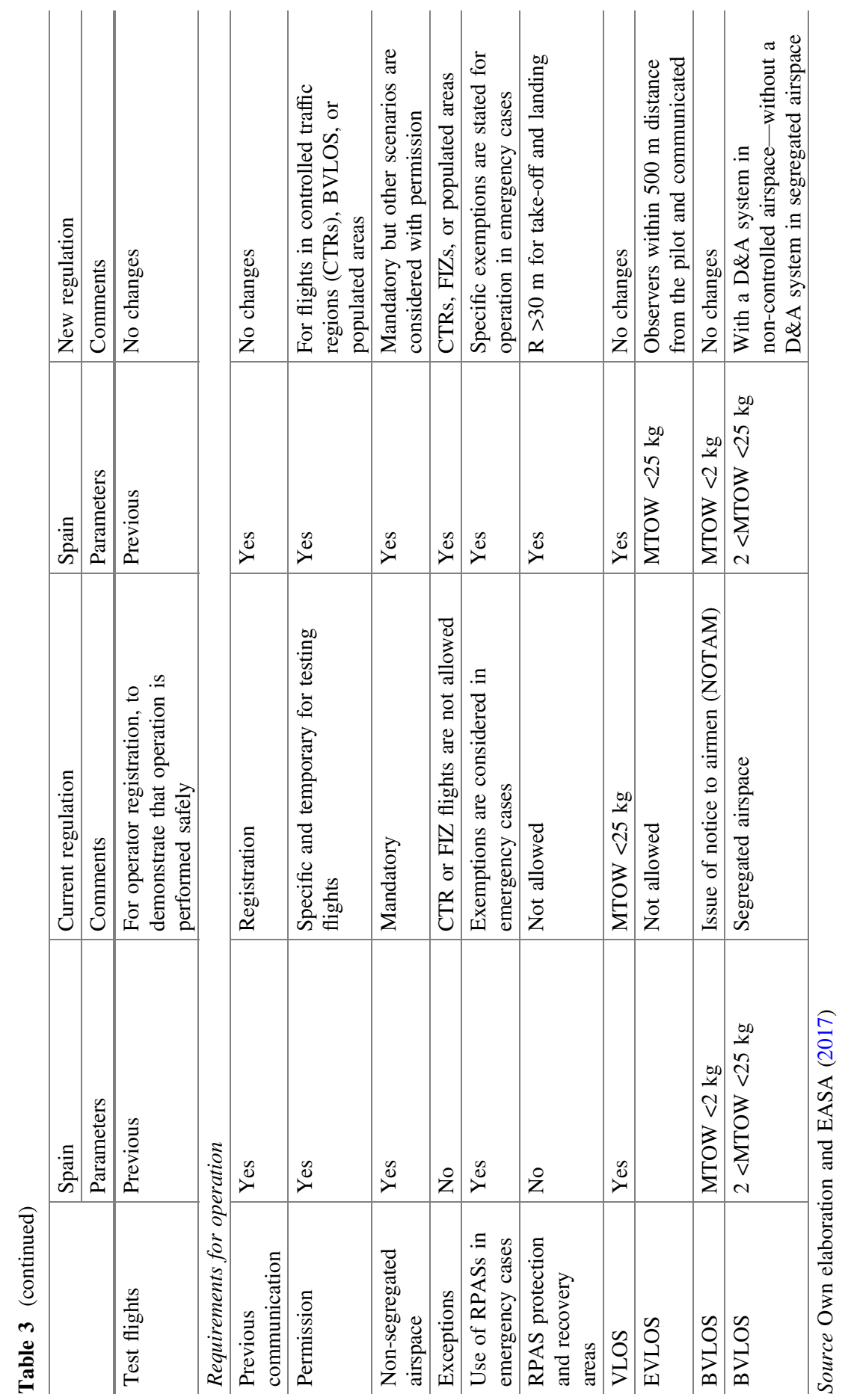


It is important to respect "no fly zones", which depend not only on the city or town but also on the commons. For example, in London, London's royal parks, Wimbledon Common, Putney Common, and Clapham Common, among others, are no-drone zones. In other cases, such as the borough of Lambeth, a commercial licence is necessary. Therefore, it is better to check with the local council before flying. There is still confusion in some areas about whether drones are permitted or not.

In the case of private property, it is possible to fly in the airspace above (but not higher than the general rule of $400 \mathrm{ft}$ ) as long as it does not cause a nuisance, infringe privacy, or otherwise interfere with the "ordinary use and enjoyment" of the land.

On the other hand, the regulation makes no distinction between indoor or outdoor flights in the case of commercial work. Certain hazard factors are heavily mitigated by the fact that the aircraft is flying in an enclosed environment and access to the venue can be controlled (CAA 2017a).

The UK Government is proposing to change the regulations so that any recreational drone weighing more than $250 \mathrm{~g}$ has to be registered. Ministers also want drones to be "electronically identifiable" on the ground so that their owners can be tracked. They are also proposing increases to the maximum fine for flying in a no-fly zone, which is currently limited to $£ 2500$.

It is not necessary to have drone insurance by law, but it will protect the operator against claims. Moreover, endangering an aircraft in flight is a criminal offence in the UK, and anyone convicted of the charge can face a prison term. Some drones have the capacity to geo-fence restricted areas, such as airports. They can also be used in "beginner" modes, which limit the height and distance that the quadcopter can fly away from the user.

In Table 4 we can observe the different parameters according to UK regulation. As our first observation, we can notice that the UK regulation is less detailed than the Spanish one reviewed.

\section{Legal Framework of Belgium}

The Belgian Civil Aviation Authority (BCAA) published the Royal Decree of 10 April 2016 "concerning the use of remote controlled aircrafts in the Belgian airspace", which regulates drone operations. It normalizes both the private and the professional use of drones and introduces a registration obligation for drones, regulates the certificates, and defines the authorized take-off and landing spots for registered drones. Moreover, manufacturers of drones need technical requirements, the delivery of conformity certificates, the drafting of a flight manual and safety analysis reporting, maintenance requirements, flight tests, and so on.

According to the BCAA (2017), we can distinguish five types of operations: 
Table 4 UK current regulation

\begin{tabular}{|c|c|c|}
\hline & UK & Current regulation \\
\hline & Parameters & Comments \\
\hline \multicolumn{3}{|c|}{ Administration and regulation } \\
\hline Regulatory body & CAA & $\begin{array}{l}\text { CAA: drones less than } 150 \mathrm{~kg} \\
\text { EASA: drones more than } 150 \mathrm{~kg}\end{array}$ \\
\hline Last normative update & 22 February 2017 & $\begin{array}{l}\text { Differences between drones up to } 7 \mathrm{~kg} \\
\text { and drones up to } 20 \mathrm{~kg} \text { (small) }\end{array}$ \\
\hline Normative identification & $\begin{array}{l}\text { The Air Navigation } \\
\text { Order } 2016\end{array}$ & Article 94 \\
\hline \multicolumn{3}{|l|}{ Limits for operation } \\
\hline MTOW & $<20 \mathrm{~kg}$ & \\
\hline $\begin{array}{l}\text { Divisions according to } \\
\text { MTOW }\end{array}$ & $<7 \mathrm{~kg} ;<20 \mathrm{~kg}$ & \\
\hline Maximum flight height & $122 \mathrm{~m}$ & \\
\hline VLOS & MTOW $<20 \mathrm{~kg}$ & \\
\hline $\begin{array}{l}\text { VLOS-distance to } \\
\text { pilot }\end{array}$ & $<500 \mathrm{~m}$ & Keeping visual contact \\
\hline EVLOS & & Need for special approval \\
\hline BVLOS & MTOW $<7 \mathrm{~kg}$ & \\
\hline $\begin{array}{l}\text { Number of RPASs } \\
\text { piloted by the same pilot }\end{array}$ & 1 & \\
\hline \multirow[t]{2}{*}{ Areas of operation } & Limited & $\begin{array}{l}\text { Non-populated areas or buildings (min. } \\
150 \mathrm{~m} \text { ) }\end{array}$ \\
\hline & & Not closer than $50 \mathrm{~m}$ to any person \\
\hline Periods of operation & & Always \\
\hline $\begin{array}{l}\text { Dangerous goods and } \\
\text { substances shipped }\end{array}$ & No & \\
\hline Flight zones & $\begin{array}{l}\text { Non-controlled } \\
\text { airspace }\end{array}$ & Safety study \\
\hline Distance from airports & Yes & $\begin{array}{l}\text { Check no-fly zones (http://www. } \\
\text { noflydrones.co.uk) }\end{array}$ \\
\hline \multicolumn{3}{|c|}{ Requirements for the operator (Documentation) } \\
\hline Registration request & No & $\begin{array}{l}\text { Unless commercial: operator's } \\
\text { certification }\end{array}$ \\
\hline Test flight request & No & \\
\hline $\begin{array}{l}\text { RPAS characterization } \\
\text { sheet }\end{array}$ & No & \\
\hline Safety study & Yes & $\begin{array}{l}\text { Risk assessment specific to the activity } \\
\text { being conducted }>20 \mathrm{~kg}\end{array}$ \\
\hline Operation manual & Yes & $\begin{array}{l}\text { Flight plan for the activity being } \\
\text { conducted }\end{array}$ \\
\hline Maintenance manual & No & \\
\hline Additional measures & No & \\
\hline Incident notifications & No & \\
\hline
\end{tabular}


Table 4 (continued)

\begin{tabular}{|c|c|c|}
\hline & UK & Current regulation \\
\hline & Parameters & Comments \\
\hline Civil liability insurance & No & $\begin{array}{l}\text { Unless commercial: operator's } \\
\text { insurance }\end{array}$ \\
\hline $\begin{array}{l}\text { Requirements according } \\
\text { to operators' origin }\end{array}$ & Yes & Professional or commercial \\
\hline $\begin{array}{l}\text { Special permit to } \\
\text { operate for foreigners }\end{array}$ & Open & \\
\hline \multicolumn{3}{|l|}{ Requirements for pilots } \\
\hline $\begin{array}{l}\text { Type of qualification } \\
\text { (license) }\end{array}$ & Qualification & $\begin{array}{l}\text { Drone pilot's commercial licence or } \\
>20 \mathrm{~kg} \text { or BVLOS }\end{array}$ \\
\hline Basic & & $\begin{array}{l}\text { Confirmation of the competencies of } \\
\text { the pilot }\end{array}$ \\
\hline Advanced & No & $\begin{array}{l}\text { Special authorization depending on the } \\
\text { activity }\end{array}$ \\
\hline Practical qualification & Yes & \\
\hline Requirements & No & \\
\hline Flight/training hours & Yes & \\
\hline $\begin{array}{l}\text { Divisions according to } \\
\text { MTOW }\end{array}$ & No & \\
\hline Medical certificate & No & \\
\hline Language & EN & \\
\hline Radiophonist license & No & \\
\hline \multicolumn{3}{|l|}{ Requirements for RPASS } \\
\hline $\begin{array}{l}\text { Identification/ } \\
\text { registration }\end{array}$ & Registration & MTOW >20 kg \\
\hline $\begin{array}{l}\text { Airworthiness } \\
\text { certification }\end{array}$ & MTOW >20 kg & \\
\hline $\begin{array}{l}\text { Command and control } \\
\text { link }\end{array}$ & & At all times \\
\hline Maintenance & No & \\
\hline Test flights & No & \\
\hline \multicolumn{3}{|c|}{ Requirements for operation } \\
\hline $\begin{array}{l}\text { Previous } \\
\text { communication }\end{array}$ & Yes & Registration (commercial) \\
\hline Permission & Yes & Commercial \\
\hline Non-segregated airspace & Yes & Mandatory \\
\hline Exceptions & No & CTR or FIZ flights are not allowed \\
\hline $\begin{array}{l}\text { Use of RPASs in } \\
\text { emergency cases }\end{array}$ & Yes & $\begin{array}{l}\text { Exemptions are considered in } \\
\text { emergency cases }\end{array}$ \\
\hline $\begin{array}{l}\text { RPAS protection and } \\
\text { recovery areas }\end{array}$ & No & Depending on the common \\
\hline VLOS & Yes & MTOW <20 kg \\
\hline
\end{tabular}


Table 4 (continued)

\begin{tabular}{l|l|l}
\hline & UK & Current regulation \\
\cline { 2 - 3 } & Parameters & Comments \\
\hline EVLOS & & Need for special approval \\
\hline BVLOS & MTOW $<7 \mathrm{~kg}$ & \\
\hline BVLOS & $7 \mathrm{~kg}<$ MTOW $>20 \mathrm{~kg}$ & Segregated airspace \\
\hline
\end{tabular}

Source Own elaboration; EASA (2017), Stöcker (2017)

- Private use: maximum higher than $10 \mathrm{~m}$ above a private terrain and the droneweighing less than $1 \mathrm{~kg}$ - must be within line of sight at all times. These flights can only happen during daylight, and they are not allowed for commercial or professional purposes.

- Model aircraft: take-off weight between 1 and $150 \mathrm{~kg}$ and used only for recreational purposes above a model aircraft terrain recognized by the BCAA, as specified in the aeronautical information package (AIP). They are not allowed for commercial or professional purposes.

- Class 2 operations: not higher than around $45 \mathrm{~m}$ above ground outside controlled airspace and outside cities or communities. Operations can only occur in daylight conditions and the drone-weighing less than $5 \mathrm{~kg}$ - must remain within the pilot's LOS at all times.

- Class 1b operations: up to around $90 \mathrm{~m}$ above ground outside controlled airspace. Moreover, more than $50 \mathrm{~m}$ clear of people and/or goods on the ground. Operations can only occur in daylight conditions and the drone-weighing less than $150 \mathrm{~kg}$-must remain within LOS at all times.

- Class 1a operations: up to around $90 \mathrm{~m}$ above ground outside controlled airspace. Moreover, closer than $50 \mathrm{~m}$ to people and/or goods on the ground or even over them or around an obstacle closer than $30 \mathrm{~m}$. Operations can only occur in daylight conditions and the drone-weighing less than $150 \mathrm{~kg}$ - must remain within line of sight at all times. All operations that are not covered in the previous categories are to be considered as Class 1a operations.

Therefore, only classes 1 and 2 can be used for commercial or professional purposes. This means:

- Registration of the drone at the BCAA;

- A certificate of competence in the case of class 2 (taking a theoretical course and passing a practical skill test with an examiner recognized by the BCAA) or a remote pilot licence in the case of class 1 (a theoretical examination organized by the BCAA and a practical skill test with an examiner recognized by the BCAA);

- An operation manual and risk assessment for class 1; 
Table 5 Belgium's current regulation (commercial or professional)

\begin{tabular}{|c|c|c|}
\hline & Belgium & Current regulation \\
\hline & Parameters & Comments \\
\hline \multicolumn{3}{|c|}{ Administration and regulation } \\
\hline Regulatory body & BCAA & $\begin{array}{l}\text { BCAA: drones less than } 150 \mathrm{~kg} \\
\text { EASA: drones more than } 150 \mathrm{~kg}\end{array}$ \\
\hline $\begin{array}{l}\text { Last normative } \\
\text { update }\end{array}$ & None & \\
\hline $\begin{array}{l}\text { Normative } \\
\text { identification }\end{array}$ & $\begin{array}{l}\text { Royal Decree of } 10 \\
\text { April } 2016\end{array}$ & $\begin{array}{l}\text { Drones are divided depending on their } \\
\text { weight into class } 2 \text { (up to } 5 \mathrm{~kg} \text { ) and class } 1 \\
\text { (up to } 150 \mathrm{~kg} \text { ) }\end{array}$ \\
\hline \multicolumn{3}{|l|}{ Limits for operation } \\
\hline MTOW & $<150 \mathrm{~kg}$ & \\
\hline $\begin{array}{l}\text { Divisions } \\
\text { according to } \\
\text { MTOW }\end{array}$ & $<5 \mathrm{~kg} ;<150 \mathrm{~kg}$ & \\
\hline $\begin{array}{l}\text { Maximum flight } \\
\text { height }\end{array}$ & $45-90 \mathrm{~m}$ & \\
\hline VLOS & MTOW $<150 \mathrm{~kg}$ & \\
\hline $\begin{array}{l}\text { VLOS-distance to } \\
\text { pilot }\end{array}$ & $<50 \mathrm{~m}$ & Keeping visual contact \\
\hline EVLOS & Not allowed & \\
\hline BVLOS & MTOW $<5 \mathrm{~kg}$ & Prior authorization (Class 1) \\
\hline $\begin{array}{l}\text { Number of RPASs } \\
\text { piloted by the same } \\
\text { pilot }\end{array}$ & 1 & Not specified \\
\hline Areas of operation & Limited & $\begin{array}{l}\text { Not prohibited zones, danger zones, } \\
\text { restricted zones, temporary segregated/ } \\
\text { reserved areas, etc. }\end{array}$ \\
\hline $\begin{array}{l}\text { Periods of } \\
\text { operation }\end{array}$ & Daytime & All cases \\
\hline $\begin{array}{l}\text { Dangerous goods } \\
\text { and substances } \\
\text { shipped }\end{array}$ & No & \\
\hline Flight zones & Non-controlled airspace & Safety study \\
\hline $\begin{array}{l}\text { Distance from } \\
\text { airports }\end{array}$ & Yes & \\
\hline \multicolumn{3}{|c|}{ Requirements for the operator (Documentation) } \\
\hline $\begin{array}{l}\text { Registration } \\
\text { request }\end{array}$ & Yes & \\
\hline Test flight request & No & \\
\hline $\begin{array}{l}\text { RPAS } \\
\text { characterization } \\
\text { sheet }\end{array}$ & No & \\
\hline Safety study & Yes & $\begin{array}{l}\text { Only class 1: risk assessment by the } \\
\text { operator }\end{array}$ \\
\hline
\end{tabular}


Table 5 (continued)

\begin{tabular}{|c|c|c|}
\hline & Belgium & Current regulation \\
\hline & Parameters & Comments \\
\hline Operation manual & Yes & $\begin{array}{l}\text { Only class 1: operation manual drafted by } \\
\text { the operator }\end{array}$ \\
\hline $\begin{array}{l}\text { Maintenance } \\
\text { manual }\end{array}$ & No & \\
\hline $\begin{array}{l}\text { Additional } \\
\text { measures }\end{array}$ & Yes & To avoid interference \\
\hline $\begin{array}{l}\text { Incident } \\
\text { notification }\end{array}$ & Yes & \\
\hline $\begin{array}{l}\text { Civil liability } \\
\text { insurance }\end{array}$ & Yes & \\
\hline $\begin{array}{l}\text { Requirements } \\
\text { according to } \\
\text { operators' origin }\end{array}$ & Yes & $\begin{array}{l}\text { Class } 1 \mathrm{a} \\
\text { (certificate of conformity for the drone) } \\
\text { Class } 1 \mathrm{~b} \text { (declaration of compliance made } \\
\text { by the operator) }\end{array}$ \\
\hline $\begin{array}{l}\text { Special permit to } \\
\text { operate for } \\
\text { foreigners }\end{array}$ & Open & \\
\hline \multicolumn{3}{|c|}{ Requirements for pilots } \\
\hline $\begin{array}{l}\text { Type of } \\
\text { qualification } \\
\text { (license) }\end{array}$ & Qualification & \\
\hline Basic (class 2) & Yes & Theoretical training + practical skill test \\
\hline Advanced (class 1) & Yes & Theoretical exam + practical skill test \\
\hline $\begin{array}{l}\text { Practical } \\
\text { qualification }\end{array}$ & Yes & \\
\hline Requirements & Yes & 16 years (class 2 ) or 18 years (class 1 ) \\
\hline $\begin{array}{l}\text { Flight/training } \\
\text { hours }\end{array}$ & No & \\
\hline $\begin{array}{l}\text { Divisions } \\
\text { according to } \\
\text { MTOW }\end{array}$ & Yes & \\
\hline Medical certificate & Yes & Class 1 \\
\hline Language & FR or NL & \\
\hline $\begin{array}{l}\text { Radiophonist } \\
\text { license }\end{array}$ & No & \\
\hline \multicolumn{3}{|c|}{ Requirements for RPASs } \\
\hline \multirow{2}{*}{$\begin{array}{l}\text { Identification/ } \\
\text { registration }\end{array}$} & Yes & \\
\hline & Registration & MTOW $>5 \mathrm{~kg}$ \\
\hline $\begin{array}{l}\text { Airworthiness } \\
\text { certification }\end{array}$ & MTOW $>5 \mathrm{~kg}$ & \\
\hline $\begin{array}{l}\text { Command and } \\
\text { control link }\end{array}$ & & At all times \\
\hline Maintenance & Yes & \\
\hline Test flights & Yes & \\
\hline
\end{tabular}


Table 5 (continued)

\begin{tabular}{l|l|l}
\hline & Belgium & Current regulation \\
\hline \multicolumn{2}{|l}{ Parameters } & Comments \\
\hline $\begin{array}{l}\text { Requirements for operation } \\
\text { Previous }\end{array}$ & Yes & $\begin{array}{l}\text { Flight notification to the BCAA before } \\
\text { start of flight (class 1) }\end{array}$ \\
\hline Permission & Yes & $\begin{array}{l}\text { Authorization to operate received from the } \\
\text { BCAA (class 1a) }\end{array}$ \\
\hline $\begin{array}{l}\text { Non-segregated } \\
\text { airspace }\end{array}$ & Yes & $\begin{array}{l}\text { Industrial complexes, nuclear power } \\
\text { plants, military zones, and other special } \\
\text { zones cannot be flown over unless } \\
\text { otherwise described in the AIP }\end{array}$ \\
\hline $\begin{array}{l}\text { Exceptions } \\
\text { Use of RPASs in } \\
\text { emergency cases }\end{array}$ & Yes & CTR or FIZ flights are not allowed \\
\hline $\begin{array}{l}\text { RPAS protection } \\
\text { and recovery areas }\end{array}$ & No & $\begin{array}{l}\text { Exemptions are considered in emergency } \\
\text { cases }\end{array}$ \\
\hline VLOS & Yes & MTOW $<150 \mathrm{~kg}$ \\
\hline EVLOS & & Not allowed \\
\hline BVLOS & $<150 \mathrm{~kg} \mathrm{MTOW}>5 \mathrm{~kg}$ & Segregated airspace \\
\hline BVLOS &
\end{tabular}

Source own elaboration and EASA (2017)

- A declaration made by the operator that the organization is in full compliance with the national requirements for class $1 \mathrm{~b}$ (starting operations only after receiving confirmation from the BCAA and notifying the BCAA of each drone flight before take-off) and the prior authorization of the BCAA for class 1a (the drone has a certificate of conformity from the BCAA or an equivalent document issued by a civil aviation authority from an EU Member State. If not, one must be obtained prior to requesting authorization);

- Forbidden zones at all times are: all controlled airspaces, prohibited zones, danger zones, restricted zones, temporary segregated/reserved areas, and so on. Industrial complexes, nuclear power plants, military zones, and other special zones cannot be flown over unless otherwise described in the AIP.

The use of completely autonomous aircrafts, that is, unmanned drones that do not allow the pilot to intervene immediately to take control over the flight, remains strictly forbidden.

Other chapters of the Royal Decree include provisions for the communication and control software that is implemented in drone technology, incident reporting obligations, mandatory insurance coverage for drone operators, and references to compliance with the applicable data protection and privacy legislation (in particular for drones with a camera functionality). 


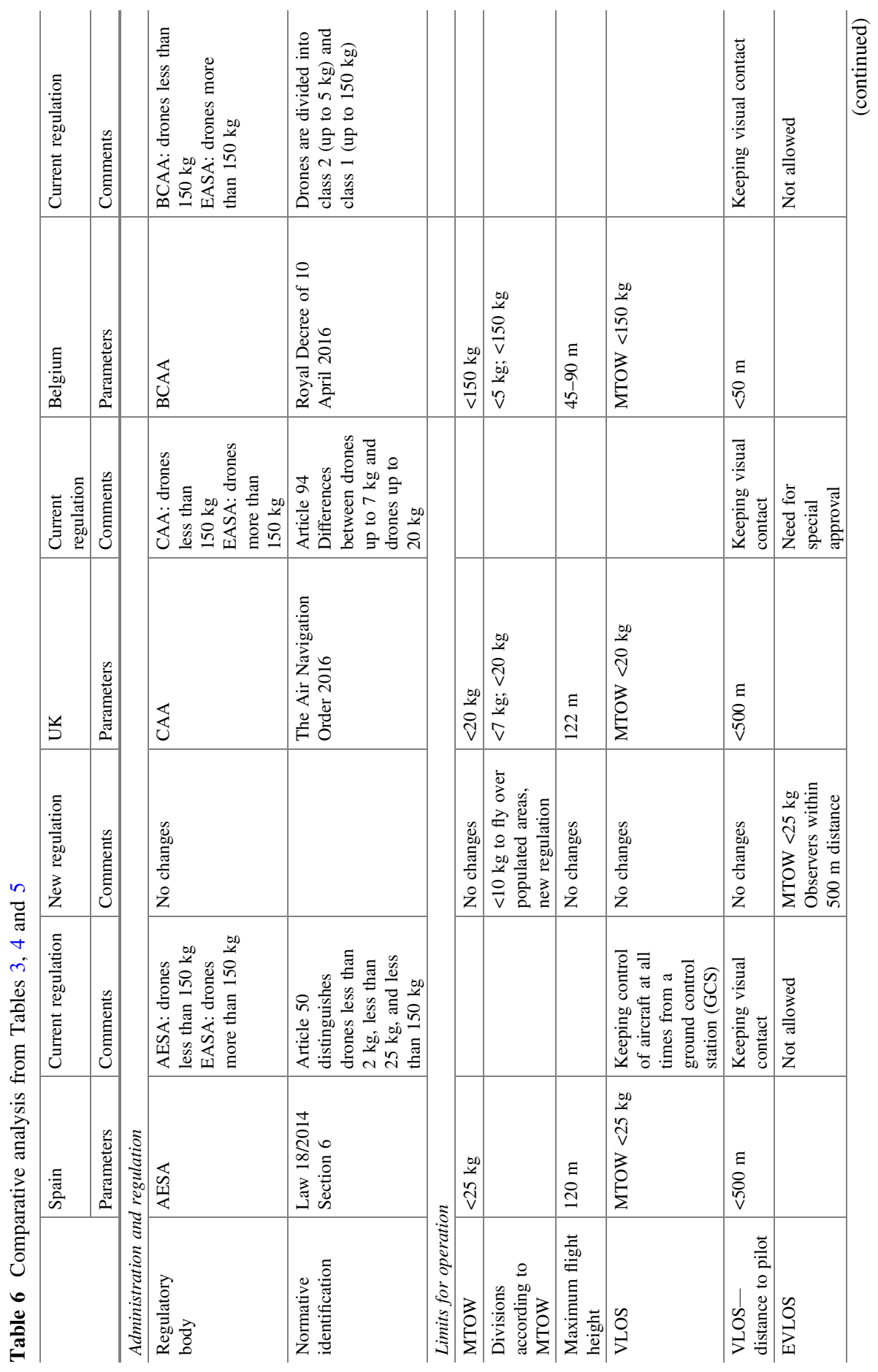




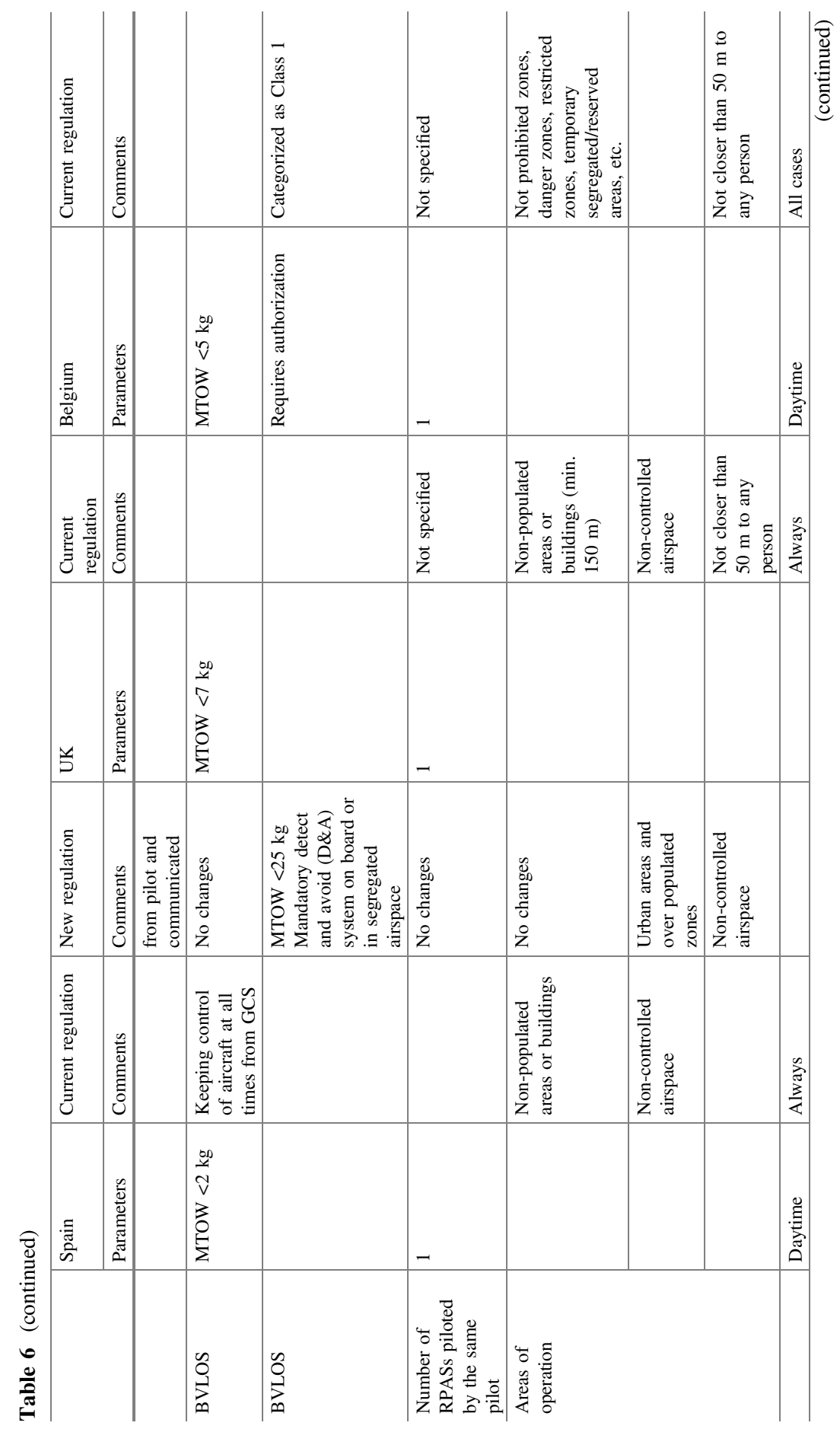




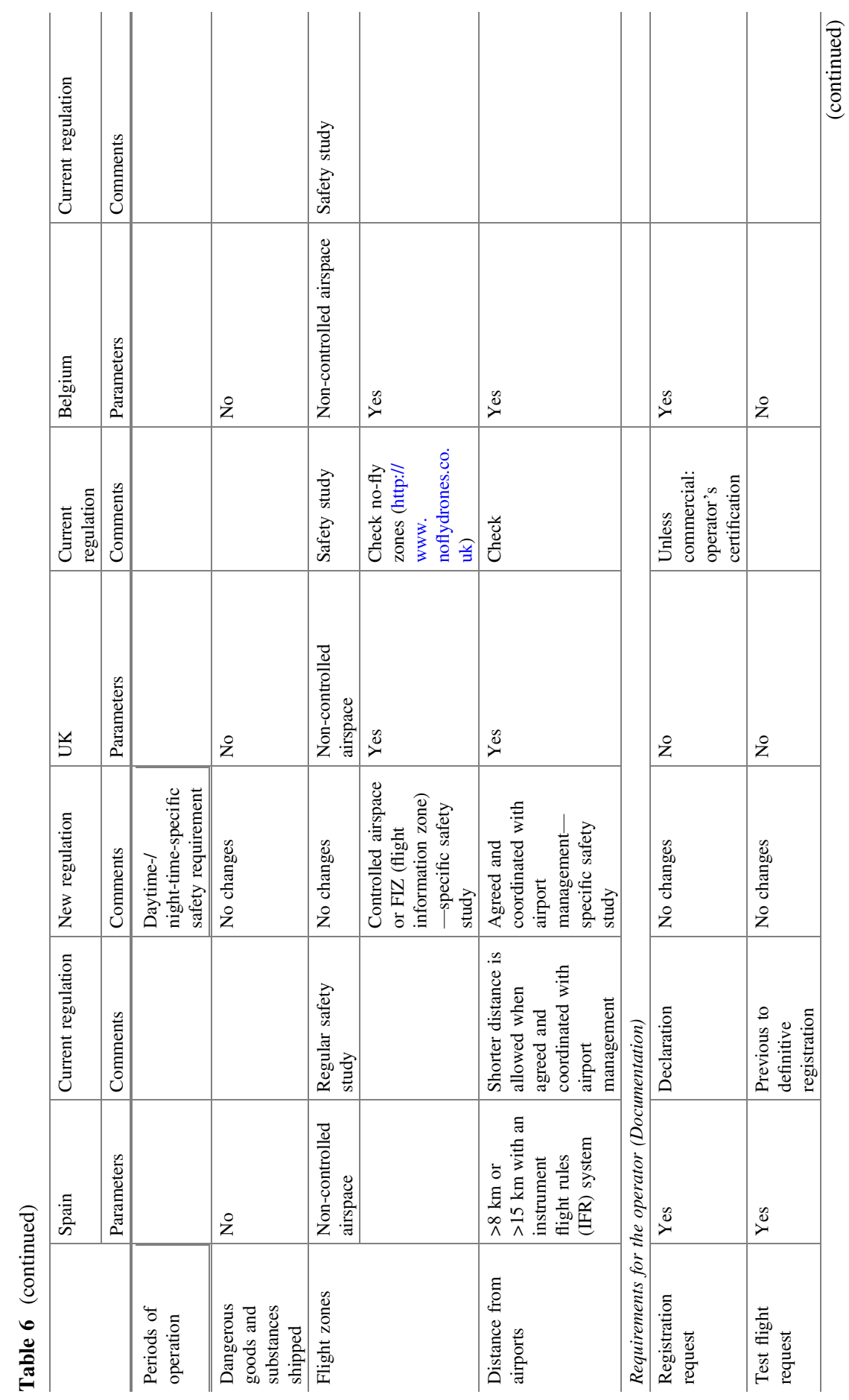




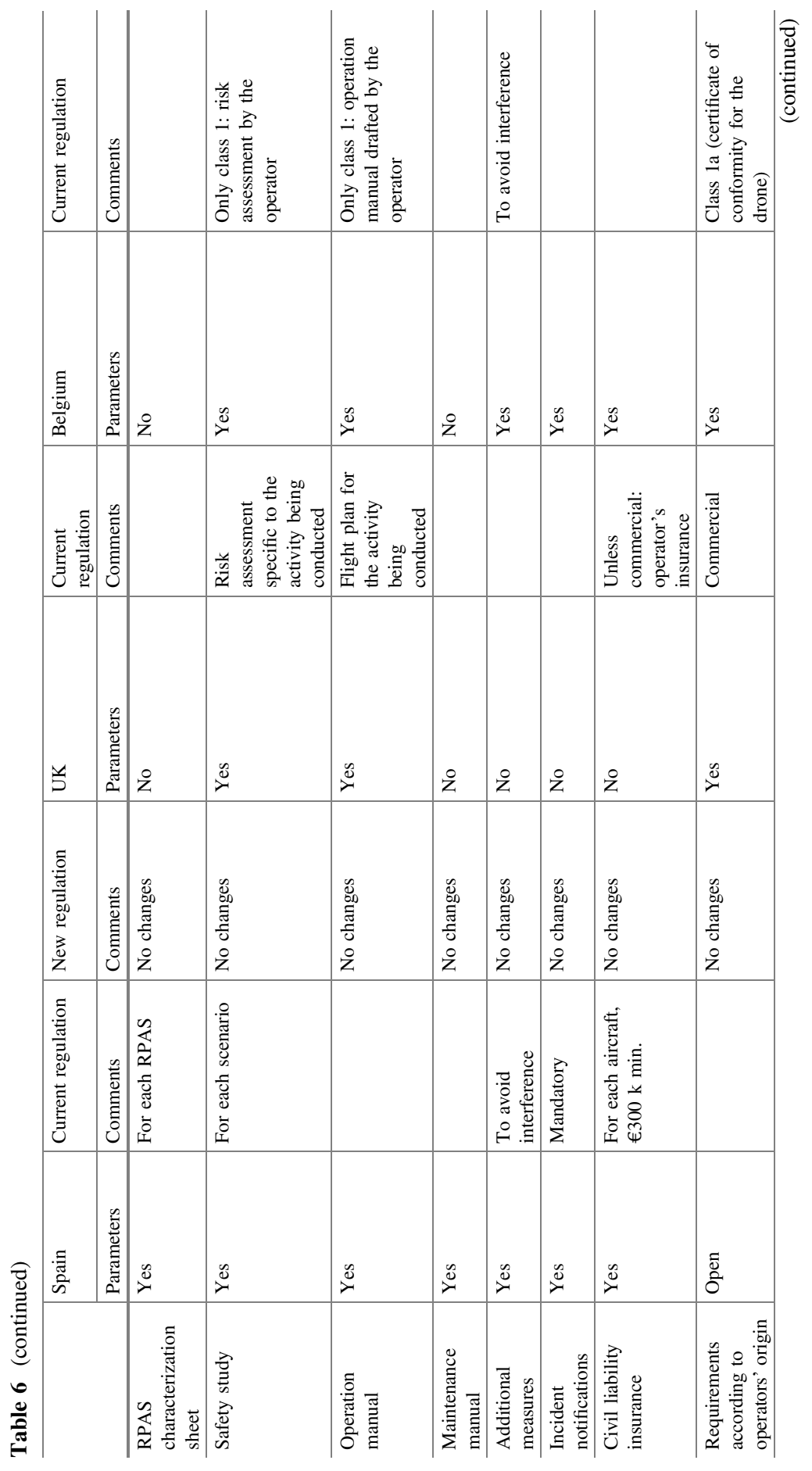




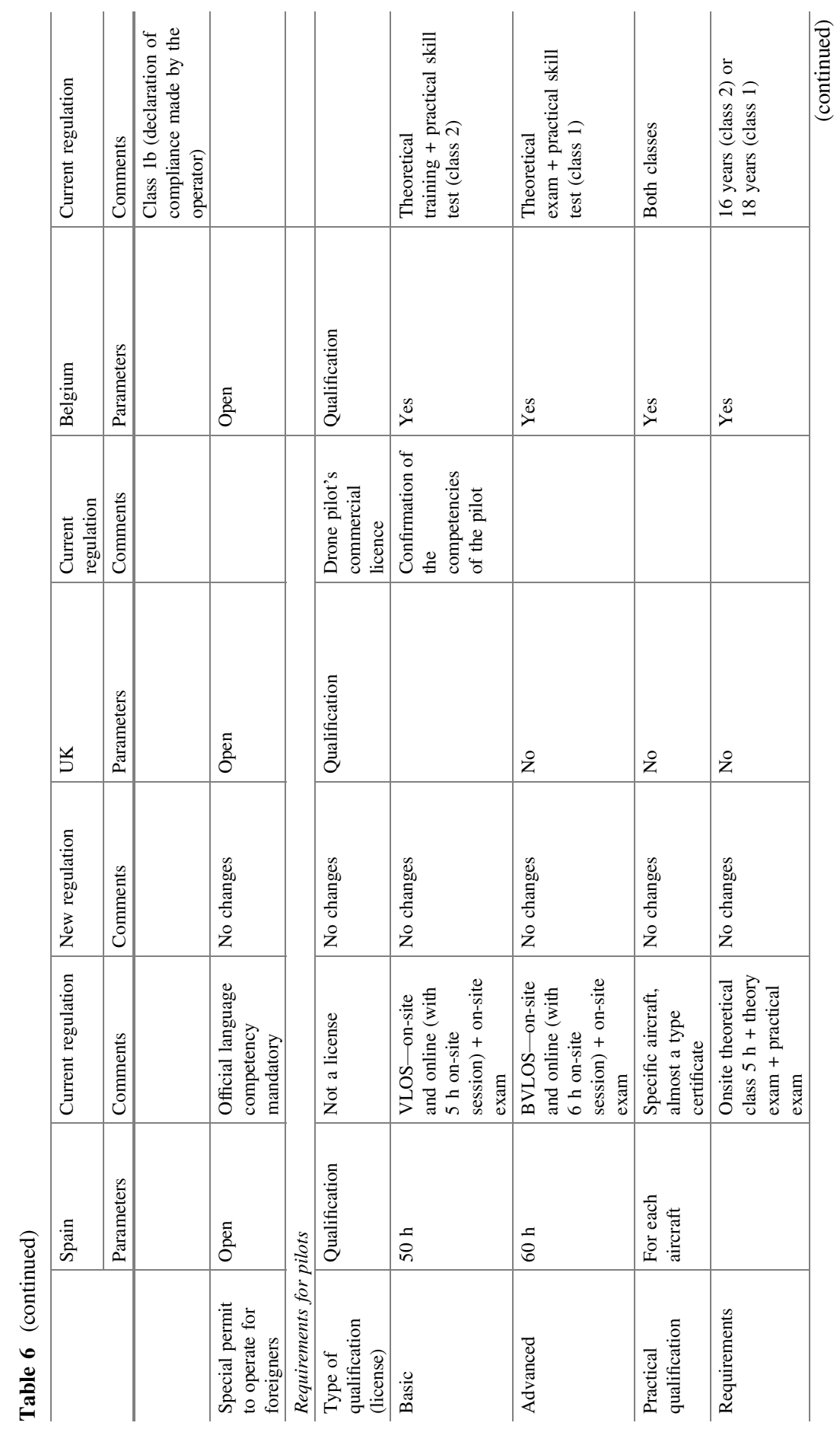




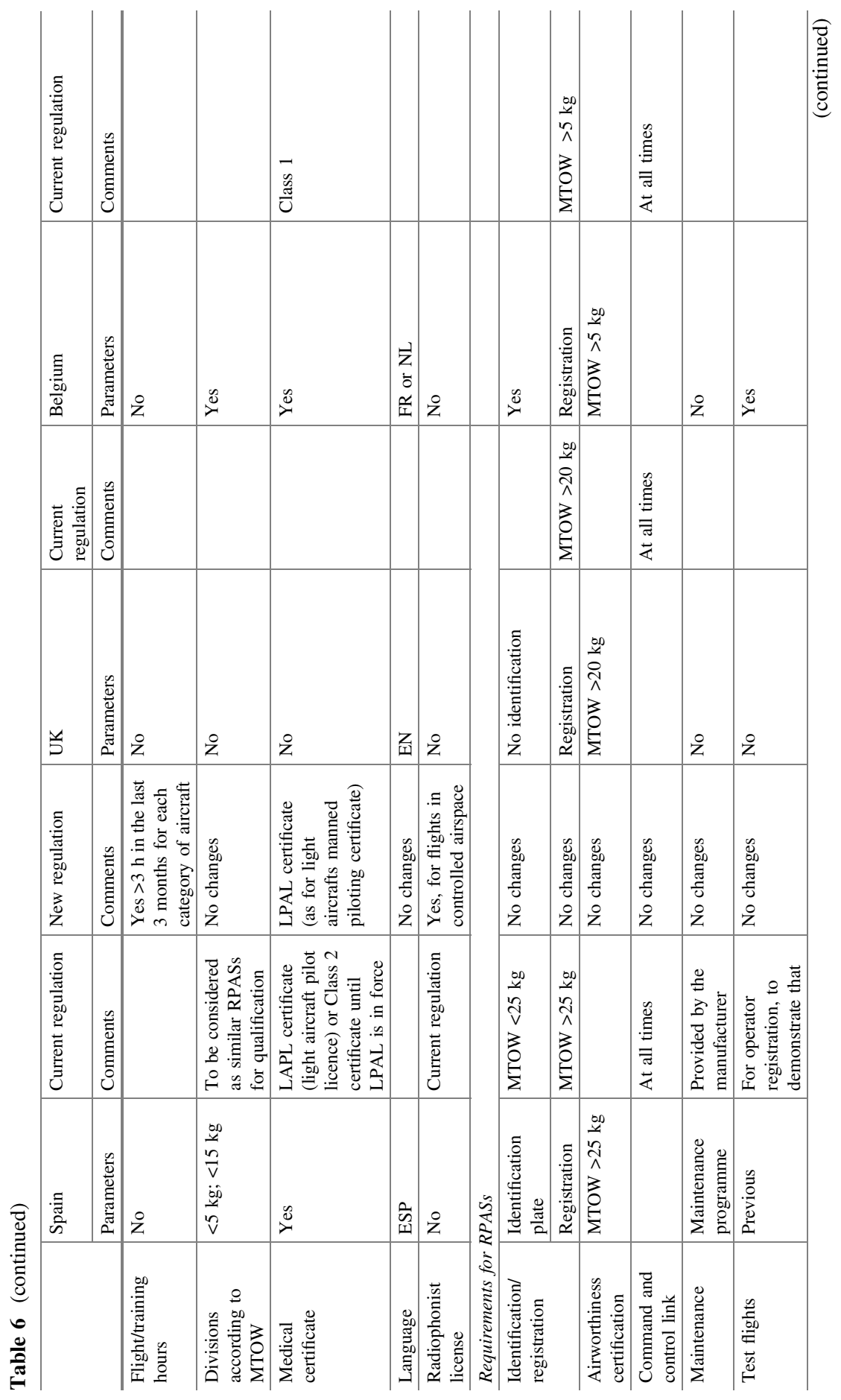




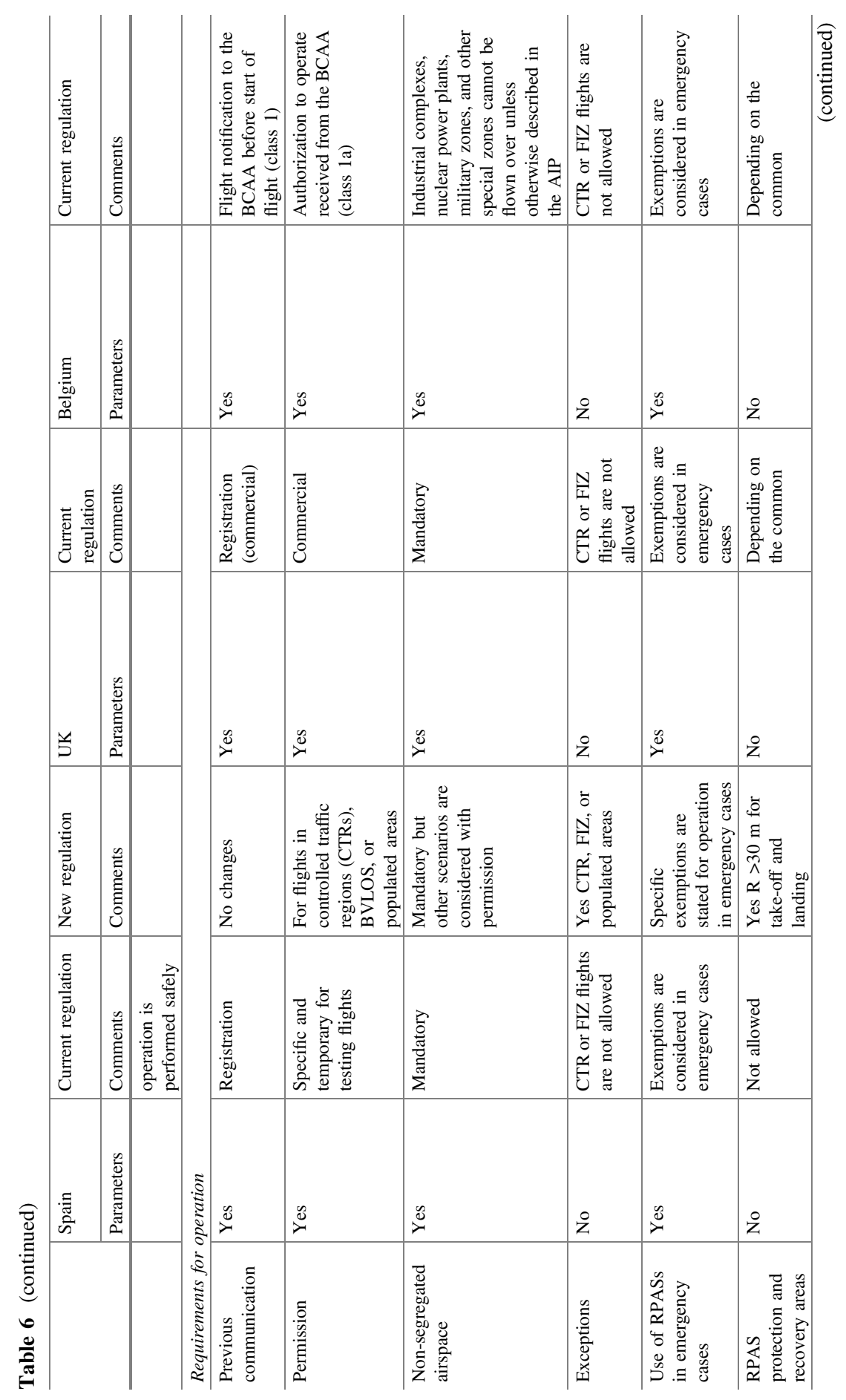




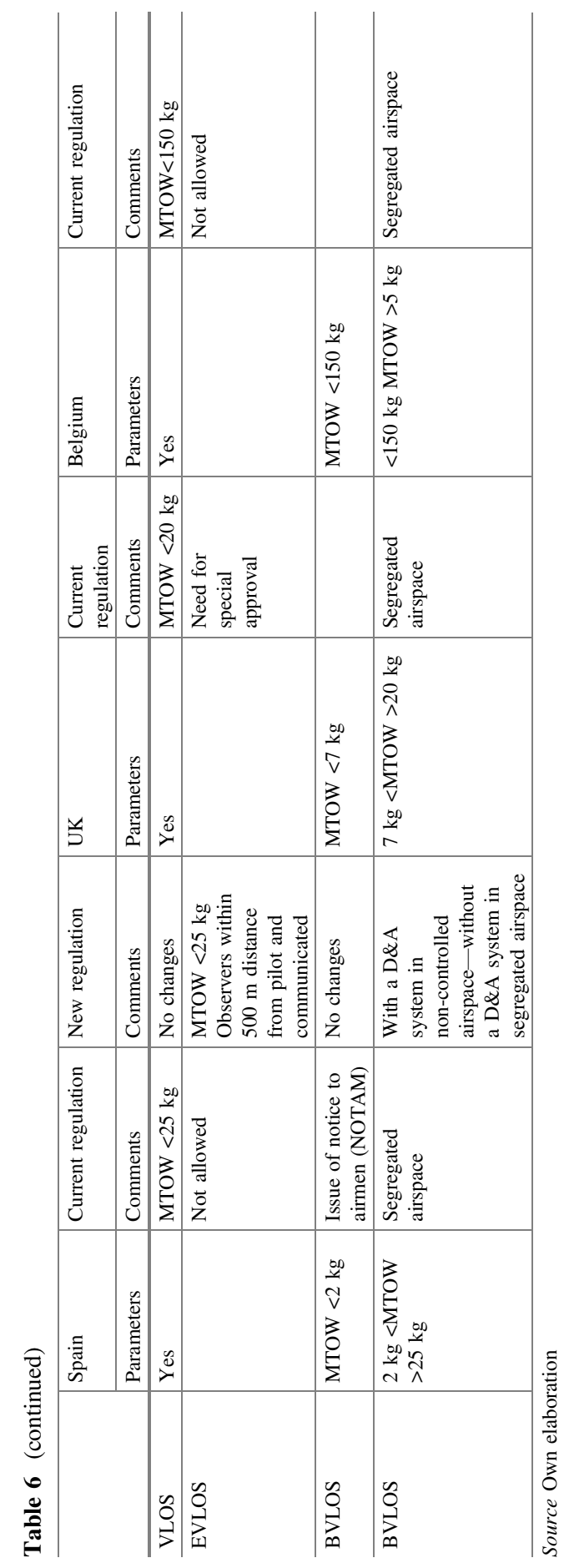


Excluded from the regulatory requirements of the Royal Decree of 10 April 2016 are (a) drones used only to fly inside buildings (indoor); (b) drones used by the military, customs authorities, the police, coastguard, and so on; and (c) certain types of model aeroplanes solely used for personal/recreational purposes, provided that they meet the strict requirements detailed in the Royal Decree.

As our focus is on the commercial or professional use of drones, we summarize the current parameters in Table 5.

\section{Comparative Analysis}

See Table 6.

\section{Conclusions}

As we can observe in Table 6, the differences among European countries regarding the operation of drones are still relevant, diminishing the competitiveness of the European drone industry. However, the future legal framework, as designed by the EASA (2017), will create legal certainty for the industry, especially concerning drone requirements in the case of commercial and professional activities.

Furthermore, distinguishing drones depending on their risk and not on their weight could solve the problems of professionals when working in another European country. As an example, we can observe big differences between countries like Belgium, France, Poland, Spain, Sweden, and the UK, where the national authority's permission is limited to $150 \mathrm{~kg}$, while other countries, such as Denmark, Finland, Lithuania, and Portugal, place the upper weight limit at $25 \mathrm{~kg}$.

\section{References}

AESA (2014) Law 18/2014, 15 October, "Approval of urgent measures for growth, competitiveness and efficiency". http://www.seguridadaerea.gob.es/media/4389070/ley_18_2014_de_15_ octubre.pdf. Accessed 10 July 2017

AESA (2017a) Drones. http://www.seguridadaerea.gob.es/lang_castellano/cias_empresas/trabajos/ rpas/default.aspx. Accessed 10 July 2017

AESA (2017b) Guidance material. http://www.seguridadaerea.gob.es/lang_castellano/cias_ empresas/trabajos/rpas/material_guia/default.aspx. Accessed 21 Sept 2017

BCAA (2017) Aviation information leaflet: drone flying. https://mobilit.belgium.be/sites/default/ files/resources/files/asil_2017_01_drone_flying.pdf. Accessed 12 July 2017

Bernauw K (2016) Drones: the emerging era of unmanned civil aviation. Zbornik Pravnog Fakulteta u Zagrebu 66(2-3):223-248

CAA (2017a) Unmanned aircraft and drones. http://www.caa.co.uk/Consumers/Unmannedaircraft-and-drones/ Accessed 10 July 2017 
CAA (2017b) The air navigation order 2016 (ANO) and regulations, CAP 393, version 5.2. http:// www.legislation.gov.uk/uksi/2016/765/contents/made. Accessed 11 July 2017

EASA (2015a) Advance notice of proposed amendment 2015-10, A-NPA. https://www.easa. europa.eu/system/files/dfu/A-NPA\%202015-10.pdf. Accessed 6 July 2017

EASA (2015b) Technical opinion. https://www.easa.europa.eu/document-library/opinions/ opinion-technical-nature. Accessed 6 July 2017

EASA (2017) Notice of proposed amendment 2017-05, B-NPA introduction of a regulatory framework for the operation of drones, unmanned aircraft system operations in the open and specific category. https://www.easa.europa.eu/system/files/dfu/NPA\%202017-05\%20\%28B\% 29.pdf. Accessed 18 August 2017

ESRG (2013) Roadmap. Available via SESARJU. http://www.sesarju.eu/sites/default/files/ documents/news/-Roadmap_130620.pdf?issuusl=ignore. Accessed 6 July 2017

ICAO (2006) Convention on international civil aviation (Chicago Convention, original 1944), Doc 7300. https://www.icao.int/publications/Documents/7300_cons.pdf. Accessed 11 July 2017

ICAO (2017) UAS toolkit. http://www4.icao.int/uastoolkit/home/about. Accessed 6 July 2017

JARUS (2015a) Terms of reference. http://jarus-rpas.org/sites/jarus-rpas.org/files/imce/attach ments/jarus_tor_v0_4.pdf. Accessed 6 July 2017

JARUS (2015b) Definition and structure of working groups. http://jarus-rpas.org/working-groups. Accessed 5 Oct 2017

Ministry of Public Works and Transport and Ministry of Defence (2016) Royal decree (draft). http://fomento.es/NR/rdonlyres/63ECAE3A-B29E-45A7-A885-D314153883EE/139826/RDRPAS 27102016.pdf. Accessed 10 July 2017

Pauner-Chulvi C (2016) The emerging use of civilian drones in Spain. Legal status and impact on the right to data protection. Revista de Derecho Político 95:83-116

Stöcker C, Bennett R, Nex F, Gerke M, Zevenbergen J (2017) Review of the current state of UAV regulations. Remote Sens 9(5):459-485

Open Access This chapter is licensed under the terms of the Creative Commons Attribution 4.0 International License (http://creativecommons.org/licenses/by/4.0/), which permits use, sharing, adaptation, distribution and reproduction in any medium or format, as long as you give appropriate credit to the original author(s) and the source, provide a link to the Creative Commons license and indicate if changes were made.

The images or other third party material in this chapter are included in the chapter's Creative Commons license, unless indicated otherwise in a credit line to the material. If material is not included in the chapter's Creative Commons license and your intended use is not permitted by statutory regulation or exceeds the permitted use, you will need to obtain permission directly from the copyright holder.

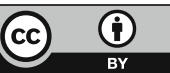




\title{
Legal and Ethical Recommendations
}

\author{
María de Miguel Molina and María Ángeles Carabal Montagud
}

\begin{abstract}
European countries have fragmented regulations about the manufacture and operation of civil drones; therefore, European institutions are trying to combine all these regulations into a common one by 2019. Until this common framework arrives, not only law but also ethics can give guidelines to the industry to satisfy national standards as well as users' concerns. The European Aviation Safety Agency promotes the highest common standards of safety and develops common safety rules at the European level. This agency and its national equivalents monitor the activity of producers and operators, but, depending on the size of the drone, this activity could cover regulation measures or ethical recommendations. In this sense the aim of our analysis is to categorize the types of hard-soft regulations that we find in the European Union. Our study is based on a content analysis from four sources of information: scientific papers, policies and regulation proposals from the European Union, the regulation and co-regulation of some European countries, and the self-regulation of some drone companies' associations. In general, few countries have chosen self-regulation as a solution to the problems, although in other economic sectors there are positive experiences. With our results we would like to give advice to the European industry as well as providing academia and policy makers with new insights.
\end{abstract}

\section{Introduction}

Different regions and countries in the European Union have diverse ways of regulating their commercial and professional activities. In some regions legal regulation is prominent, and there are different normative tools to regulate every economic activity in a detailed manner (the French model, regulation-centred countries).

M. de Miguel Molina $(\varangle) \cdot$ M. Á. Carabal Montagud

Universitat Politècnica de València, Valencia, Spain

e-mail: mademi@omp.upv.es

(C) The Author(s) 2018

M. de Miguel Molina and V. Santamarina Campos (eds.), Ethics and Civil Drones,

SpringerBriefs in Law, https://doi.org/10.1007/978-3-319-71087-7_5 
Therefore, individual freedom and organizational decision making are reduced, because legal regulation covers the majority of cases. This is the case of countries such as Spain or Belgium. On the other hand, other regions develop less regulation but use courts' interpretation more, based on previous experiences (the AngloSaxon model, jurisprudence-centred countries), giving more freedom to individuals and organizations but less legal security in some cases. For example, this is the situation of the United Kingdom (UK).

However, in the last years, new hybrid models have proposed joint decision making among companies (self-regulation) or between companies and stakeholders, such as the public administration (meta-regulation or co-regulation). These models enhance reflexion and comparison of the "best practices" to follow some excellent organizations to ensure more ethical decision making when legal regulation cannot cover every single case. Some economic and third-sector organizations, such as videogames or sportive competitions, have developed their own rules or soft law in combination with the public administration.

According to Coglianese and Mendelson (2010: 152), and depending on the tool that we use (self-regulation or co-regulation), the organization's discretion increases or diminishes in a pyramid, from freedom to regulation.

As we saw in the chapter "Spain-UK-Belgium Comparative Legal Framework", the regulation of small drones (less than $150 \mathrm{~kg}$ ) depends on their national regulations. Safety parameters play a key role in the design of civil UASs or RPASs (unmanned aircraft controlled remotely by a pilot, that is, aircraft controlled by a pilot who is not on board). These parameters apply to the producers and the offer of different services by the operators.

Moreover, drones produce other concerns about their use regarding people's personal data (privacy) (Smith 2015). This is mainly an ethical issue on which policy makers should work with stakeholders (Finn and Wright 2016), especially in the case of micro-drones or indoor drones that do not require a flight licence or training to be used. However, the European data protection regulations serve to reinforce this aspect of drones' use.

According to Stöcker et al. (2017), by 2016 more than $80 \%$ of the 65 countries with national regulations legislated about drones for 2 reasons: the increasing technology and high-profile safety incidents. Even small mistakes could result in crashes that threaten the health, well-being, and property of the public (Rao et al. 2016).

By now it seems that the necessity of visual line of sight (VLOS) and the lateral distance of the pilot (normally $500 \mathrm{~m}$ ) are the main shared parameters. Moreover, the minimum lateral distances to people are in the range of 30-150 m.

Nevertheless, as technology is very difficult to regulate, other tools, such as co-regulation and self-regulation, although soft instruments, are useful alternatives for the manufacturers and operators of civil drones (Stöcker et al. 2017). Therefore, we could classify the best practices that fit better with each type of regulation: legal regulation, co-regulation, and self-regulation. 


\section{Drones' European Legal and Ethical Framework}

As Clarke (2014a: 291) highlights in relation to the drone surveillance sector, "the aviation industry has operated for the last seven decades within the framework provided by an international convention, resulting in considerable similarities across almost the entire world", but "no such cohesive influence exists in the field of ..." other regulations, such as for civil drones. Furthermore, he is quite critical of soft forms of regulation, as he underlines that the impact of organizational and industry self-regulation is very limited.

Moreover, "despite its theoretical promise, co-regulation too appears unlikely to satisfy the need. Formal regulation therefore appears to be essential" (Clarke 2014a: 291). He gives examples of other successful sectors, and in Clarke (2016: 153) he shows some co-regulation initiatives that could provide more commitment to the drone sector in the short-medium term, due to the fact that in "co-regulation ... industry or user organisations perform regulatory functions within a framework set by a government agency". That is because interaction among stakeholders may produce a consensus on a public policy approach in an area in which there is considerable uncertainty (Freeman and Freeland 2014).

As a starting point, and agreeing with Stöcker et al. (2017), all drone regulations have one common goal: "minimizing the risks to other airspace users and to both people and property on the ground". They propose to analyse the different parts that national regulations cover:

- Technical requirements (regarding the product);

- Operational limitations (regarding the operator: distance to airports/strips, limitations to flying over people, limitations over congested areas, prohibited areas, maximal flying height, visual line of sight, beyond visual line of sight, and so on);

- Administrative procedures (certificates, registration, insurance);

- Human resource requirements (qualification of pilots);

- Implementation of ethical constraints (here they include requirements for data protection and privacy).

Thus, as we can observe, the majority of concerns are related to safety, and they only give ethical concerns in relation to privacy. Safety tests are necessary before marketing a drone, and different key attributes of the product should be checked (Clarke 2014b). However, from our point of view, safety can also be included in ethical limitations. Moreover, different current regulations, at least in the European Union, can cover privacy issues.

Regarding data protection, the current European Directive guarantees rights of access, rectification, erasure, and blocking. In addition, the new Directive and Regulation on Data Protection (to commence at the end of May 2018) include the same standards (European Parliament 2016a, b). However, to apply them, it is essential to inform the subjects. Besides, the necessary storage measures should be adopted when processing, according to the European Union Directive. 
As mentioned in the chapter "Spain-UK-Belgium Comparative Legal Framework", the European Union has developed some documents to clarify the regulation of civil drones. The current national harmonization actions undertaken by the EASA define riskless open and riskier specific categories. The main European documents are the following:

- Riga Declaration on remotely piloted aircraft (drones), "Framing the future of aviation", Riga, 6 March 2015 (European Commission 2015).

- EASA (European Aviation Safety Agency). A-NPA 2015-10. Introduction of a regulatory framework for the operation of drones. 31 July 2015 (EASA 2015).

- European Union (2015). Opinion 01/2015 on privacy and data protection issues relating to the utilisation of drones, 16 June. Article 29, Data Protection Working Party, 01673/15/EN WP 231 (European Union 2015).

- Juul (2015) Civil drones in the European Union. PE 571.305. Members' Research Service, European Parliamentary Research Service (Juul 2015).

To reach a common legal framework, the European Union has developed several stakeholder consultations, although no legislation has been approved yet.

Furthermore, in other regions, such as the United States, Kaminski (2016) underlines the efforts of the National Telecommunications and Information Administration (NTIA) at the Department of Commerce to host multi-stakeholder negotiations on consumer privacy around drones for industry self-regulation and co-regulation. Moreover, in some specific sectors, the different stakeholders should be informed of the advantages of using drones. For example, Sandbrook (2015) remarks on the importance of identifying the social risks of drones for biodiversity conservation and how they could be mitigated to ensure good ethical practice and minimize the risk of unintended consequences. Accordingly, self-regulation and co-regulation could be adjusted to the different actors' needs.

Industrial manufacturers and professional users are expected to play a key role and contribute to the decision regarding whether UAVs will be a tool for everyone or just for professionals (Stöcker et al. 2017). Codes of conduct are the most-used self-regulation tool to set rules and standards, such as the promises by companies to regulate themselves in the general interest of society (Laudon and Laudon 2016). Some associations of manufacturers and operators of drones have developed codes of conduct (Arkin 2016) that could also provide guidance to the regulators of in-place legal standards and practices (Freeman and Freeland 2014).

As drones' technology changes fast, new organizations' adoption of drone technologies must be paired with clear articulation of their ethical use and full transparency with the public (Culver 2014). For example, information security seems to have received less attention in regulations. However, some measures could be designed by default (Coopmans 2014) to protect information and information systems from unauthorized access, use, disclosure, disruption, modification, perusal, inspection, recording, or destruction (Braun et al. 2015). Some security concerns include hacking, hijacking, cyber-attacks, or other types of vulnerability. Thus, the encryption of communications among all the devices could permit secure 
computer-RPAS communication and avoid unauthorized access by third parties. For example, there is the possibility of data anonymization, such as pixels to avoid facial recognition when using a camera (Ruchaud and Dugelay 2015).

\section{Drones' National Legal and Ethical Frameworks}

Following the analysis of the three European countries involved in the AiRT project, we have compared Spain, the UK, and Belgium. The situation in the different European countries is very similar. Normally co-regulation is used to provide the drones' pilots with practical training, while self-regulation in general is not developed in a specific code of conduct.

The training of drones' operators is a key factor for the industry (Clarke 2016). Requiring operators to be licensed and have insurance can impose standards and ensure safety (Luppicini and So 2016).

As a detailed legal study was undertaken in the chapter "Spain-UK-Belgium Comparative Legal Framework", we focus our analysis on ethical tools (Table 1):

In Spain the National Agency of Aerial Safety (AESA) works with different organizations to provide pilots with practical training. In this sense authorization for training is given to (AESA 2017):

- Drone manufacturers

- Organizations authorized by a drone manufacturer

- Licensed operators with their own pilots

- Authorized training organizations (ATOs).

After the training and its assessment (as described by the AESA), these organizations have to send the Agency a dossier containing all the required official documents. This certificate should specify the drone type and model that the person is able to pilot. The certificate it is not necessary in all cases, although it could add value in the case of professional work. Moreover, licensed pilots normally contract insurance, and this constitutes another trust guarantee.

Table 1 Co-regulation and self-regulation initiatives in Spain, the UK, and Belgium

\begin{tabular}{l|l|l|l}
\hline & Spain & UK & Belgium \\
\hline $\begin{array}{l}\text { Regulatory } \\
\text { body }\end{array}$ & AESA & CAA & BCAA \\
\hline $\begin{array}{l}\text { Normative } \\
\text { identification }\end{array}$ & $\begin{array}{l}\text { Law 18/2014 } \\
\text { Section 6 }\end{array}$ & $\begin{array}{l}\text { The Air Navigation Order } \\
\text { 2016 (Article 94) }\end{array}$ & $\begin{array}{l}\text { Royal Decree of 10 } \\
\text { April 2016 }\end{array}$ \\
\hline Co-regulation & $\begin{array}{l}\text { AESA (practical } \\
\text { training) }\end{array}$ & $\begin{array}{l}\text { CAA (permissions for small } \\
\text { drone operators) }\end{array}$ & $\begin{array}{l}\text { BCAA (practical } \\
\text { training) }\end{array}$ \\
\hline Self-regulation & AEDRON & ARPAS-UK & BeUAS \\
\hline
\end{tabular}

Source Own elaboration 
On the side of self-regulation, even though the Spanish Association of RPAS (AERPAS) is the biggest companies' association as it includes manufacturers and operators, it has no code of conduct. There is a smaller association, AEDRON (2016), the Spanish Association of Drones and Similar, just for operators, which has developed one. According to it, some interesting points that the regulation does not cover are:

- To help other pilots in the case of necessity;

- To identify the environmental impacts of the activity in order to minimize them;

- To use biodegradable materials and recycle them correctly;

- To sign the operation's zone correctly.

In the UK, as well as in the previous case, the Civil Aviation Authority (CAA) does not provide training but gives this task to the national qualified entities (NQEs) to assess the competence of people operating small unmanned aircraft (CAA 2015). That is the standard permission to conduct commercial operations with a small unmanned aircraft (drone) weighing $7 \mathrm{~kg}$ or less.

Regarding self-regulation, the Association of RPAs (ARPAS-UK 2017) has its own code of conduct. The code, which is very brief and general, is built on three specific themes: safety, professionalism, and respect. Nevertheless, some of its statements could be useful:

- To report incidents to the police, national authority, or relevant industry body;

- To ensure that RPASs will be piloted by individuals who are properly trained and competent to operate the aircraft or its systems;

- To ensure that RPAS flights will be conducted only after a thorough assessment of the risks associated with the activity. Reliability, performance, and airworthiness are established standards.

The case of Belgium is the same. The Belgium Civil Aviation Authority (BCAA) does not provide training, but the Direction Générale Transport Aérien (DGTA) gives this competence to certain organizations (approved training organizations-ATOs). According to article 35 of the Royal Decree of 10 April 2016 on the use of unmanned aircraft in Belgian airspace, the candidates for the position of instructor must meet the following prerequisites:

- Hold a valid remote pilot license;

- Have completed a teaching and learning course;

- Have flight experience of at least $100 \mathrm{~h}$ as a remote pilot.

A flight instructor candidate who meets the previous cumulative conditions must pass a practical examination before becoming an RPAS examiner designated by the DGTA. The RPAS flight instructor rating is valid for a period of three years (SPF Mobilité et Transports 2015).

Concerning self-regulation, the BeUAS—La Fédération Belge de l'Aviation Télépilote or Belgian Unmanned Aircraft System Association-just provides a "Charter" (BeUAS 2017) containing a few ethical principles. Among them, we highlight the following: 
- Always fly over people with permission;

- Always bear in mind the type or class of drone in use;

- Do not fly a drone at night;

- Respect the operating manual at all times if applicable, knowing the drone's limits and adapting the flight in function.

To sum up, we can observe that self-regulation is focused on operators and the main concerns regarding the ethical aspects of their work are the following:

- To work in a helpful environment, prioritizing safety all the time;

- To minimize the environmental impacts;

- To give all the necessary information and request permission to the people affected by the activity;

- To report incidents;

- To pilot when there is the competence and training to do so in a safe way, respecting the operating manual;

- To analyse the risks associated with the activity, bearing in mind the class of drone in use and the limits.

We think that these measures are in line with the draft of the new European Union regulation but could be useful while that regulation is being approved and implemented.

\section{Industry Perceptions}

We conducted focus groups in Spain, the UK, and Belgium during February 2017 to contrast with the creative industry the concerns about safety and security when using civil drones for their work. Each group was formed by six to seven expert informants from different sectors, and half of them have a pilot drone license. In total we collected information from twenty people.

The participants attribute the most importance to the experience of the pilot, particularly regarding professional work. For them, trust can be gained when there is training and insurance to cover any eventuality. Additionally, an encrypted Wi-Fi connection is necessary in all cases to give information to the subjects when recording.

Furthermore, the role of the producers is more focused on default measures and giving advice and instructions to the operators.

\section{Conclusions}

From our point of view, manufacturers and operators are different actors, even though the traditional way of distinguishing standards is to categorize them into active and passive measures all together for both groups. Manufacturers are key 
actors, as they develop safety and security measures, but operators can just use them, so they are less involved in the design of the product. Manufacturers should work with operators and other stakeholders to improve those measures, because knowing actors' concerns can add considerable value to the product.

Manufacturers could be more centred on safety by default and security by default in designing drones to avoid risky situations in their use. Operators should have the appropriate training to avoid any risk, even for small drones. Maybe if the industry is able to develop very precise drones, the pilots could be inexperienced, but at this moment we think that these cases should be reduced to indoor environments where the risks can be better assessed.

Even if ethics and codes of conduct can help manufacturers and operators of drones, co-regulation whereby public agencies could give some kind of certificate would be an additional element to reinforce other kinds of work in which flight licenses are not compulsory.

As we have observed, in the European countries, co-regulation now is only centred on operators and practical training. The participation of other stakeholders to ensure safety and security is not included. However, other agencies could be involved in the industry, for example to ensure information security, product safety, or data protection by applying different best-practice standards.

Moreover, on the side of regulation, and following Rao et al. (2016: 89), the introduction of compulsory specific insurance could be helpful to create a registry of devices to link each drone to its owner and to help to assign responsibility for illegal activities. On the same line, Boucher (2016: 1409) stresses that citizens see drone regulations as analogous to car regulations; therefore, they should have "mandatory licensing, registration of devices, and mandatory third-party insurance". For him the current focus on public acceptance of civil drone development will move to the development of civil drones that are acceptable to society.

The European Union (2015) recommends that producers can help by giving advice on their packaging and using codes of conduct to self-regulate the industry. Other tools, such as impact assessment or the participation of a Data Protection Officer, could improve clients' reliability. The industry could be proactive in case regulation is not enough.

\section{References}

AEDRON (2016) Code of conduct. https://www.aedron.com/codigo-etico. Accessed 18 July 2017 AESA (2017) Practical training, authorised organizations. http://www.seguridadaerea.gob.es/ LANG_EN/cias_empresas/trabajos/rpas/req_pilotos/quien_form_practica.aspx. Accessed 18 July 2017

Arkin RC (2016) Ethics and autonomous systems: perils and promises. Proc IEEE 104(10): $1779-1781$

ARPAS-UK (2017) Code of conduct. https://www.arpas.uk/mem-code-of-conduct/. Accessed 17 July 2017 
BeUAS (2017) BeUAS charter. https://www.beuas.be/fr/membership/beuas-charter. Accessed 20 July 2017

Boucher P (2016) "You wouldn't have your granny using them": drawing boundaries between acceptable and unacceptable applications of civil drones. Sci Eng Ethics 22:1391-1418

Braun S, Friedewald M, Valkenburg G (2015) Civilizing drones: military discourses going civil? Sci Technol Stud 28(2):73-87

CAA (2015) Guidance on using small drones for commercial work. https://www.caa.co.uk/ Commercial-industry/Aircraft/Unmanned-aircraft/Small-drones/Guidance-on-using-small-dronesfor-commercial-work/. Accessed 18 July 2017

Clarke R (2014a) The regulation of civilian drones' impacts on behavioural. Comput Law Secur Rev 30(3):286-305

Clarke R (2014b) Understanding the drone epidemic. Comput Law Secur Rev 30(3):230-246

Clarke R (2016) Appropriate regulatory responses to the drone epidemic. Comput Law Secur Rev 32(1):152-155

Coglianese C, Mendelson E (2010) Meta-regulation and self-regulation. In: Baldwin R, Cave M, Lodge M (eds) The Oxford handbook of regulation. Oxford University Press, Oxford, pp 146-168

Coopmans C (2014) Architecture requirements for ethical, accurate, and resilient unmanned aerial personal remote sensing. In: 2014 International Conference on Unmanned Aircraft Systems (ICUAS), pp. 1-8

Culver KB (2014) From battlefield to newsroom: ethical implications of drone technology in journalism. J Mass Media Ethics Explor Quest Media Moral 29(1):52-64

European Aviation Safety Agency (EASA) (2015) Advance notice of proposed amendment 2015-10, A-NPA. https://www.easa.europa.eu/system/files/dfu/A-NPA\%202015-10.pdf. Accessed 6 July 2017

European Commission (2015) Riga Declaration on remotely piloted aircraft (drones) "Framing the future of aviation". https://ec.europa.eu/transport/sites/transport/files/modes/air/news/doc/ 2015-03-06-drones/2015-03-06-riga-declaration-drones.pdf. Accessed 18 July 2017

European Parliament (2016a) Directive (EU) 2016/680 of the European Parliament and of the Council, of 27 April 2016, on the protection of natural persons with regard to the processing of personal data by competent authorities for the purposes of the prevention, investigation, detection or prosecution of criminal offences or the execution of criminal penalties, and on the free movement of such data, and repealing Council Framework (Decision 2008/977/JHA). Accessible via EUR-LEX. http://eur-lex.europa.eu/legal-content/EN/TXT/?uri=uriserv:OJ.L_. 2016.119.01.0089.01.ENG. Accessed 18 July 2017

European Parliament (2016b) Regulation (EU) 2016/679 of the European Parliament and of the Council, of 27 April 2016, on the protection of natural persons with regard to the processing of personal data and on the free movement of such data, and repealing Directive 95/46/EC (General Data Protection Regulation). Accessible via EUR-LEX. http://eur-lex.europa.eu/eli/ reg/2016/679/oj. Accessed 18 July 2017

European Union (2015) Opinion 01/2015 on privacy and data protection issues relating to the utilisation of drones. Article 29 Data Protection Working Party, 01673/15/EN WP 231. Accessible via the European Commission. http://ec.europa.eu/justice/data-protection/index_en. htm. Accessed 18 July 2017

Finn RL, Wright D (2016) Privacy, and ethics for civil drone practice: a survey of industry, regulators and civil society organisations. Comput Law Secur Rev 32(4):577-586

Freeman PK, Freeland RS (2014) Politics \& technology: U.S. policies restricting unmanned aerial systems in agriculture. Food Policy 49(1):302-311

Juul M (2015) Civil drones in the European Union. PE 571.305. Members' Research Service, European Parliamentary Research Service. Accessible via European Parliament. http://www. europarl.europa.eu/RegData/etudes/BRIE/2015/571305/EPRS_BRI(2015)571305_EN.pdf. Accessed 18 July 2017

Kaminski ME (2016) When the default is no penalty: negotiating privacy at the NTIA. Denver Univ Law Rev 93(4):925-949 
Laudon KC, Laudon JP (2016) Management information systems: managing the digital firm. Pearson, Harlow

Luppicini R, So A (2016) A technoethical review of commercial drone use in the context of governance, ethics, and privacy. Technol Soc 46:109-119

Rao B, Gopi AG, Maione R (2016) The societal impact of commercial drones. Technol Soc 45:83-90

Ruchaud N, Dugelay JL (2015) Privacy protection filter using StegoScrambling in video surveillance. In: CEUR workshop proceedings, vol 1436. http://ceur-ws.org/Vol-1436/ Paper62.pdf. Accessed 18 July 2017

Sandbrook C (2015) The social implications of using drones for biodiversity conservation. Ambio 44(4):636-647

Smith ML (2015) Regulating law enforcement's use of drones: the need for state legislation. Harv J Legis 52(2):423-454

Stöcker C, Bennett R, Nex F, Gerke M, Zevenbergen J (2017) Review of the current state of UAV regulations. Remote Sens 9(5):459-485

SPF Mobilité et Transports (2015) Instructeur ou examinateur RPAS. https://mobilit.belgium.be/fr/ transport_aerien/drones/instructeur_ou_examinateur_rpas. Accessed 20 July 2017

Open Access This chapter is licensed under the terms of the Creative Commons Attribution 4.0 International License (http://creativecommons.org/licenses/by/4.0/), which permits use, sharing, adaptation, distribution and reproduction in any medium or format, as long as you give appropriate credit to the original author(s) and the source, provide a link to the Creative Commons license and indicate if changes were made.

The images or other third party material in this chapter are included in the chapter's Creative Commons license, unless indicated otherwise in a credit line to the material. If material is not included in the chapter's Creative Commons license and your intended use is not permitted by statutory regulation or exceeds the permitted use, you will need to obtain permission directly from the copyright holder. 


\title{
Conclusions
}

\author{
Virginia Santamarina Campos and Stephan Kröner
}

\begin{abstract}
This final chapter exposes the main conclusions of the book and gives some general brief guidelines to the different actors that could be of interest in the drone sector.
\end{abstract}

\section{European Policies for the Drone Sector}

At present no common regulatory framework for different European countries exists; thus, each one regulates the activity of drone stakeholders differently. However, it can be stated that a legal framework is possible in the near future, thanks to the European Agency of Safety Aviation (EASA) in cooperation with the industries concerned.

In the case of the employment of drones for professional and commercial activities, it is highly expected that those regulations will help to increase this incipient sector while at the same time ensuring the safety and security of all European citizens who could be affected by drone activities.

\section{European Drone Industry}

Although the sector has both technological and economic importance in Europe, there are substantial barriers that are preventing it from expanding. As for any industrial development, (over) regulation can be one of the biggest barriers to overcome. In the case of Europe, a conglomerate of independent countries with a common European market, with scattered non-uniform regulations, this might be

\footnotetext{
V. Santamarina Campos $(\bowtie) \cdot S$. Kröner

Universitat Politècnica de València, Valencia, Spain

e-mail: virsanca@upv.es

(C) The Author(s) 2018 
even more relevant. It is obvious that, in the case of drones, two important considerations that limit their use have to be taken into account: security/ethical issues and safety. Only if Europe is able to solve these issues quickly and with concise and easy-to-understand policies, while maintaining European standards, will the European industries have the possibility to compete with the big global players from the USA and China. This will not just give an impulse to the European industries (and in particular SMEs) but will also have a considerable impact in the fields of academic, technological, business, and social development.

Although a big part of the evolution of the drone industry has occurred in the last years, led mainly by military needs, nowadays the most innovative drone use is also associated with collaboration (health and drugs delivery, emergency surveillance, security, etc.) and commercial efficiency (agriculture, topography, etc.).

We have distinguished among the different segments within the drone industry as end users. Since their needs and characteristics are totally different, their strategies should be considered separately. In the chapter "The Drone Sector in Europe" five different segments were identified:

- Toys, for which the final customers are children or young people and the use is educational.

- Hobby/leisure, for which the final customers are young people and adults and the drones are designed for recreational uses.

- Professional, for which the end users are drone pilots and the drones are employed for aerial filming and photography services.

- Commercial, for which the final customers are companies that use drones for agriculture, media, mining, energy, or construction activities.

- Military purposes (vigilance, combat, etc.), for which governments are the final customers.

The professional segment is facing vibrant competition among the European, North American, and Chinese manufacturers. Although the market was led by European companies, the Chinese giant DJI is growing fast, followed by other companies. As previously shown, the regulations are heavily constraining the end users, as they are confronting the need for permits and licences and/or geographical restrictions to carry out their work properly. Thus, the corresponding European organism needs to achieve a common agreement for all European countries as soon as possible to maintain and improve competitiveness. If this is achieved, the commercial segment could have a much brighter future than has been foreseen up to now. Regulations do not always affect the final prices (in the case of drones) so much, but on the other hand they provide legal certainty, which is very important for companies, investors, or insurers. This is especially true for indoor use, while outdoor regulations do not particularly affect the behaviour of the end user, since the main activities are carried out in rural areas or in emergency situations. Most of these drones can be easily adapted for a specific purpose, and associated services, like software and support, add value to the final product. In this area European and North American companies are the leaders in this group. 


\section{Current Legal Frameworks}

The differences among European countries in relation to the operation of drones are still relevant, lowering the competitiveness of the European drone industry. However, the future legal framework, as designed by the EASA, will give the industry legal certainty and reassurance, especially in the case of commercial and professional activities. Distinguishing drones by their risk and not by their weight could solve the issues encountered by professionals when working in other European countries.

Moreover, it could be helpful to introduce compulsory specific insurance to create a registry of devices and link each drone to its owner to ensure that responsibility can be clearly assigned for illegal activities (not only in the case of professional drones or drones with a weight of more than $20 \mathrm{~kg}$ ).

Delving deeper into the matter and talking to the implied industry players, we realized that their main concern about indoor drone use is that professional work needs to be very accurate and therefore piloting experience is necessary. Likewise, indoor environments should be safer for the people affected by a drone's work and drone control should be easy if certain licenses and insurance measures could be applied in all the European countries.

\section{Ethical Recommendations}

Manufacturers are key actors, as they develop safety and security measures, while operators, as end users, are less involved in the product design. Nevertheless, manufacturers should work together not only with operators but also with other stakeholders to improve those measures, because knowing actors' concerns can add considerable value to the product.

Manufacturers could integrate more safety and security by default when designing drones, avoiding improper and risky use. Operators should receive appropriate training to avoid any kind of risk, even when it comes to navigating small-sized drones. Although ethics and codes of conduct can help manufacturers and operators of drones, co-regulation whereby public agencies could give some kind of certificate could be an additional element to reinforce work situations in which flight licenses are not compulsory.

In the European countries, co-regulation is currently only centred on operators and practical training. The participation of other stakeholders to ensure safety and security is not included. However, other agencies could be involved in the industry, for example to ensure information security, product safety, or data protection by applying different best-practice standards. 
The European Union recommends that producers can help by giving advice on their packaging and using codes of conduct to self-regulate the industry. Other tools, such as impact assessment or the participation of a Data Protection Officer, could improve clients' reliability. As a conclusion, the industry could be proactive in case regulation is not enough.

Open Access This chapter is licensed under the terms of the Creative Commons Attribution 4.0 International License (http://creativecommons.org/licenses/by/4.0/), which permits use, sharing, adaptation, distribution and reproduction in any medium or format, as long as you give appropriate credit to the original author(s) and the source, provide a link to the Creative Commons license and indicate if changes were made.

The images or other third party material in this chapter are included in the chapter's Creative Commons license, unless indicated otherwise in a credit line to the material. If material is not included in the chapter's Creative Commons license and your intended use is not permitted by statutory regulation or exceeds the permitted use, you will need to obtain permission directly from the copyright holder.

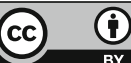




\section{Index}

B

By default, 5, 80, 84, 89

C

Categories, 38, 48, 50, 62, 80

Civil drones, 1, 4, 5, 37, 43, 47, 53, 77-80, 83, 84

Classification, 2, 35

Codes of conduct, 80, 84, 89, 90

Commercial, 2, 3, 7, 9, 11-13, 26-31, 37, 39, $40,43,44,59-63,68-70,72,74,77,82$, 87-89

Co-regulation, 5, 77-81, 84, 89

D

Data protection, $37,65,78-80,84,89$

E

EASA, 3, 36-40, 44, 47-49, 53, 58, 60, 62, 63, $65,66,74,80,87,89$

\section{I}

Indoor, 2, 3, 5, 38, 48, 59, 74, 78, 88

Insurance, 4, 13, 14, 27, 35-37, 39, 40, 43, 45, $56,59,61,64,65,69,79,81,83,84,89$

$\mathbf{L}$

Licences, 30, 39, 48, 88

\section{$\mathbf{M}$}

Manufacturers, 3, 5, 10, 13, 15, 16, 19, 21, 23-28, 30, 31, 35-37, 40, 59, 78, $80-84,88,89$

Market, 2-4, 7, 9, 10, 12-15, 26-28, 30, 36, $40,47,87,88$

MTOW, 44-46, 54, 57, 58, 60-67, 71, 73

\section{o}

Operators, 4, 5, 24, 27, 29, 31, 35, 37, 39, 40, 43-45, 49, 56, 61, 64, 65, 69, 77, 78, 80-84, 89

$\mathbf{P}$

Parameters, 5, 36, 44, 52, 53, 59, 74, 78

Pilots, 29, 35, 37, 40, 44, 45, 49, 79, 81, 82, 84, 88

Privacy, 4, 5, 7, 9, 29, 37, 39, 59, 65, 78-80

Professional, 2-5, 7, 15, 24, 30, 31, 35, 37, 40, $43,44,52,53,59,62,63,74,77,80,81$, $83,87-89$

\section{$\mathbf{R}$}

Regulation, 2, 3, 7, 29, 36, 39, 40, 44, 47-49, 51-54, 57, 59, 60, 63, 66, 71, 77-84, 87, 90

Risks, 35, 38, 43, 51, 79, 80, 82-84

RPAS, 2, 8, 27, 28, 32, 35, 45-50, 56, 58, 60, $61,63,65,69,72,81,82$

\section{S}

Safety, 1-3, 5, 7-10, 27, 29, 30, 36, 37, 39, 40, 43-52, 55, 56, 59, 60, 63, 67-69, 77-84, 87-89

Security, 1, 2, 5, 13, 26, 27, 29, 37, 39, 40, 51, $78,80,83,84,87-89$

Self-regulation, 5, 77-83

Small drones, 43, 53, 78, 84

V

VLOS, 3, 45, 46, 49, 54, 56, 58, 60, 61, 63, 65, $66,70,73,78$ 
Open Access This book is licensed under the terms of the Creative Commons Attribution 4.0 International License (http://creativecommons.org/licenses/by/4.0/), which permits use, sharing, adaptation, distribution and reproduction in any medium or format, as long as you give appropriate credit to the original author(s) and the source, provide a link to the Creative Commons license and indicate if changes were made.

The images or other third party material in this book are included in the book's Creative Commons license, unless indicated otherwise in a credit line to the material. If material is not included in the book's Creative Commons license and your intended use is not permitted by statutory regulation or exceeds the permitted use, you will need to obtain permission directly from the copyright holder.

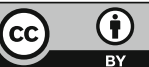

